\title{
Niet-routinematige vaardigheden in hbo-profielen
}

Citation for published version (APA):

Allen, J., Belfi, B., Fouarge, D., Holtrop, N., \& Kozole, S. (2021). Niet-routinematige vaardigheden in hboprofielen. ROA. ROA Reports No. 003 https://doi.org/10.26481/umarep.2021003

Document status and date:

Published: 02/06/2021

DOI:

10.26481/umarep.2021003

Document Version:

Publisher's PDF, also known as Version of record

\section{Please check the document version of this publication:}

- A submitted manuscript is the version of the article upon submission and before peer-review. There can be important differences between the submitted version and the official published version of record.

People interested in the research are advised to contact the author for the final version of the publication, or visit the DOI to the publisher's website.

- The final author version and the galley proof are versions of the publication after peer review.

- The final published version features the final layout of the paper including the volume, issue and page numbers.

Link to publication

\footnotetext{
General rights rights.

- You may freely distribute the URL identifying the publication in the public portal. please follow below link for the End User Agreement:

www.umlib.nl/taverne-license

Take down policy

If you believe that this document breaches copyright please contact us at:

repository@maastrichtuniversity.nl

providing details and we will investigate your claim.
}

Copyright and moral rights for the publications made accessible in the public portal are retained by the authors and/or other copyright owners and it is a condition of accessing publications that users recognise and abide by the legal requirements associated with these

- Users may download and print one copy of any publication from the public portal for the purpose of private study or research.

- You may not further distribute the material or use it for any profit-making activity or commercial gain

If the publication is distributed under the terms of Article $25 \mathrm{fa}$ of the Dutch Copyright Act, indicated by the "Taverne" license above, 
Maastricht University

\title{
Niet-routinematige vaardigheden in hbo-profielen
}

\author{
Jim Allen \\ Barbara Belfi \\ Didier Fouarge \\ Niels Holtrop
}

Sven Kozole

\section{ROA Rapport}

ROA-R-2021/3

Researchcentrum voor Onderwijs en Arbeidsmarkt | ROA Research Centre for Education and the Labour Market / ROA 


\title{
Colofon
}

(c) Researchcentrum voor Onderwijs en Arbeidsmarkt (ROA). Niets uit deze uitgave mag op enige manier worden verveelvoudigd zonder voorafgaande schriftelijke toestemming van de directeur van het ROA.

\author{
Researchcentrum voor Onderwijs en Arbeidsmarkt \\ Postbus 616 \\ 6200 MD Maastricht \\ $\mathrm{T}+31433883647$ \\ $\mathrm{F}+31433884914$ \\ secretary-roa-sbe@maastrichtuniversity.nl \\ www.roa.nl \\ School of Business and Economics \\ Maastricht University \\ Vormgeving \\ ROA secretariaat, Maastricht
}

ISBN: 978-90-5321-599-9

ISSN: 2666-8858

mei 2021

\section{NRO)}

Dit onderzoek is (mede) gefinancierd door het Nationaal Regieorgaan Onderwijsonderzoek (dossiernummer 405-00-860-008). 


\section{Inhoud}

Voorwoord v v v v v

1 Inleiding 1

1.1 Het groeiende belang van niet-routinematige vaardigheden voor
hoogopgeleiden

$\begin{array}{ll}1.2 & \text { Onderzoeksvraag en aanpak } \\ 1.3 & \text { Opbouw }\end{array}$

1.3 Opbouw rapport 3

2 Wat zijn niet-routinematige vaardigheden? $\mathbf{5}$

2.1 Automatisering en de vraag naar niet-routinematige vaardigheden 5

2.2 Naar een organisatiemodel van niet-routinematige vaardigheden $\quad 5$

3 Methode van tekstanalyse 11

$\begin{array}{ll}3.1 \text { Methodekeuze } & 11\end{array}$

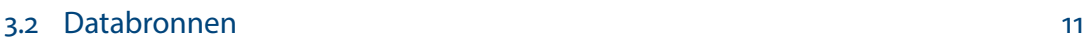

3.3 De lexicon methode 16

$\begin{array}{ll}\text { 3.4 Ontwikkeling van het lexicon } & 17\end{array}$

$\begin{array}{ll}\text { 3.5 Kwantificeren van niet-routinematige vaardigheden } & 18\end{array}$

$\begin{array}{ll}3.6 & \text { Robuustheid van de maatstaf } \\ 20\end{array}$

4 Resultaten van de tekstanalyse van opleidingsprofielen 21

$\begin{array}{ll}4.1 & \text { Inleiding } \\ & 21\end{array}$

4.2 Aanwezigheid van competentieclusters per HOOP-sector - bachelor 21

4.3 Aanwezigheid van vaardigheden per HOOP-sector - bachelor 23

4.4 Aanwezigheid van vaardigheden per opleiding - bachelor 29

4.5 Aanwezigheid van vaardigheden per opleiding - master 31

4.6 Samenhang van vaardigheden 32

5 Resultaten van vergelijkingen tussen vaardigheden die aan bod komen in opleidingen en de daadwerkelijke niet-routinematige vaardigheden $\begin{array}{ll}\text { van afgestudeerden } & 35\end{array}$

$\begin{array}{ll}5.1 \text { Inleiding } & 35\end{array}$

5.2 Match tussen HBO-Monitor vaardigheden en text-mining subclusters $\quad 36$

5.3 Rangordening van vaardigheden in text-mining analyses en corresponderende HBO-Monitor competentiematen 41

5.4 "Goede" en "minder goede" matches tussen verschillende operationalisaties 42

5.5 De relatie tussen text-mining en HBO-Monitor maten bij masteropleidingen 48 
6 Conclusie en discussie $\quad 51$

$\begin{array}{ll}6.1 & \text { Organisatiemodel } \\ 6.2 & 51\end{array}$

6.2 Belangrijkste resultaten 52

6.3 Beleidsaanbevelingen 54

6.4 Lessen en vooruitzicht $\quad 55$

$\begin{array}{ll}\text { Literatuur } & 57\end{array}$

Appendix 1: Text-mining scores per cluster, bacheloropleidingen 59

Appendix 2: Text-mining scores per cluster, masteropleidingen 63

Appendix 3: Text-mining scores per subcluster, bacheloropleidingen 65

Appendix 4: Text-mining scores per subcluster, masteropleidingen $\quad 73$ 


\section{Voorwoord}

Door automatisering en globalisering veranderen de taken van werkenden op de Nederlandse arbeidsmarkt. Routinematige taken kunnen door machines worden uitgevoerd of worden uitbesteed aan het buitenland. Dit geldt vooralsnog niet voor nietroutinematige taken, die soms zelfs talrijker en complexer kunnen worden als gevolg van de toenemende automatisering en globalisering. Doordat taken veranderen, verandert ook de vraag naar vaardigheden door werkgevers die niet-routinematige vaardigheden (ook wel brede vaardigheden genaamd zoals creativiteit, analytisch vermogen en communicatieve vaardigheden) steeds meer waarderen. Instellingen in het hoger onderwijs moeten inspelen op deze veranderende vraag. In dit onderzoek bieden wij, aan de hand van tekstanalyses, voor het eerst een kwantificering aan van de mate waarin niet-routinematige vaardigheden verwerkt zijn in de huidige profielomschrijvingen van hbo-opleidingen. Daarnaast onderzoeken wij de mate waarin afgestudeerden van die opleidingen aangeven dat zij daadwerkelijk over deze vaardigheden bezitten en de mate waarin deze vaardigheden worden vereist door hun werkgevers. Deze multimethode aanpak vergroot zodoende het zicht op het aanbod van niet-routinematige vaardigheden onder hbo-afgestudeerden enerzijds en de vraag naar deze vaardigheden door de arbeidsmarkt anderzijds. Onze tekstanalyse-aanpak van onderwijsprofielen is vernieuwend en wordt voor het eerst toegepast in deze context. Dit onderzoek biedt dan ook een proof of concept voor toepassing in andere domeinen.

Dit onderzoek, uitgevoerd met bekostiging uit het NRO programma Kortlopend Beleidsgericht Onderzoek Hoger Onderwijs, biedt dan ook een proof of concept voor toepassing in andere domeinen. 



\section{Inleiding}

\subsection{Het groeiende belang van niet-routinematige vaardigheden voor hoogopgeleiden}

De wereld van vandaag verandert snel en in vele opzichten. Door de toegenomen automatisering en informatisering heeft de relatief statische industriële samenleving van de vorige eeuw plaatsgemaakt voor een dynamische informatie- en kennismaatschappij, waarin de ontwikkeling en circulatie van kennis centraal staat. Deze technologische vernieuwingen hebben op de arbeidsmarkt tot gevolg gehad dat de routinematige vervaardiging van standaardproducten steeds meer worden uitgevoerd door computers en robots. De werkzaamheden die zijn overgebleven bestaan uit taken die niet standaard kunnen worden voorgeprogrammeerd en in hoge mate vragen om flexibiliteit, creativiteit en probleemoplossend vermogen (Autor, 2015). Een ander gevolg van de toegenomen informatisering voor de arbeidsmarkt is dat het hierdoor veel eenvoudiger is geworden om over grenzen heen te communiceren en samen te werken. Door deze mondiale samenwerkingen verspreidt nieuwe kennis zich sneller dan ooit. Tegelijkertijd is het door de vervagende grenzen ook veel makkelijker en goedkoper geworden om eenvoudige productieprocessen in het buitenland te laten uitvoeren, hetgeen de arbeidsmarktpositie van vooral lager- en middelbaaropgeleide werkenden heeft verslechterd (Goos \& Manning, 2007).

Ook de arbeidsmarktpositie van hoogopgeleide werkenden is door bovengenoemde ontwikkelingen komen te veranderen. Enerzijds dienen hoogopgeleiden in hun werk het enorme potentieel van de nieuwe technologieën om te zetten in gerealiseerde productiviteit, anderzijds moeten ze veel meer dan voorheen een weg zien te navigeren door een wereld die voortdurend in verandering is. Beide ontwikkelingen vereisen een nieuwe mix van kennis en vaardigheden. Het gaat hierbij niet alleen om een zwaardere nadruk op de niet-routinematige vaardigheden die ze van oudsher - zij het in mindere mate - nodig hadden, zoals leidinggeven, probleemoplossend vermogen, creatief denken en informatieanalyse (Weinberger, 2014), en interpersoonlijke vaardigheden (Deming, 2017). Ook zijn er een aantal nieuwe vaardigheden bijgekomen die door de toegenomen automatisering, informatisering en globalisering in werkzaamheden van hoger opgeleiden worden vereist, zoals digitale geletterdheid, interculturele- en zelfregulerende vaardigheden. Autor en collega's (Autor, Levy \& Murnane, 2003) onderscheiden niet-routinematige vaardigheden in twee hoofdcategorieën, namelijk vaardigheden die nodig zijn om abstracte taken uit te voeren, en vaardigheden die nodig zijn om fysieke taken te verrichten. De tweede hoofdcategorie is vooral - maar niet uitsluitend - van belang in middelbare en lagere functies, bijvoorbeeld maaltijden bezorgen, een vrachtwagen besturen of een hotelkamer schoonmaken. De eerste categorie 
daarentegen, de vaardigheden die nodig voor abstracte taken, is vooral het domein van hoogopgeleide werknemers zoals medische specialisten, financiële adviseurs en ontwerpers. Dit levert een belangrijke uitdaging voor hoger onderwijsinstellingen, die studenten niet alleen de benodigde vakkennis bij moeten brengen, maar ook de nietroutinematige vaardigheden die ze nodig zullen hebben om optimaal te functioneren in hun toekomstige banen.

In reactie op de toenemende vraag naar niet-routinematige vaardigheden op de arbeidsmarkt, heeft het hoger onderwijs in de afgelopen decennia grote veranderingen doorgemaakt. Zo wordt bijvoorbeeld steeds vaker gebruik gemaakt niet-traditionele werkvormen die ontwikkeling in deze vaardigheden dient te stimuleren, zoals gezamenlijke groepsprojecten, projectgericht- en probleemgestuurd onderwijs. In plaats van kennisoverdracht door een docent, wordt in deze werkvormen door de studenten zelf nieuwe kennis ontwikkeld in wisselwerking met de omgeving. (Allen, Belfi, \& Borghans, 2020; Baepler, Walker, \& Driessen, 2014). Echter, ondanks dergelijke onderwijsvernieuwingen blijkt uit recent werkgeversonderzoek dat er nog altijd discrepanties bestaan tussen de mate waarin afgestudeerden over niet-routinematige vaardigheden beschikken en de mate waarin de arbeidsmarkt hierom vraagt (Casner-Lotto \& Benner, 2006; Manyika et al., 2011).

\subsection{Onderzoeksvraag en aanpak}

Een belangrijke vraag in dit verband, waarop het antwoord vooralsnog onbekend is, is in welke mate niet-routinematige vaardigheden op dit moment in de leerdoelen van Nederlandse hoger onderwijsopleidingen verankerd zijn. Hierdoor is het vooralsnog lastig om te bepalen of afgestudeerden van het Nederlandse hoger onderwijs bij afstuderen wel in voldoende mate over bepaalde vaardigheden beschikken, en zo niet, waar dit aan ligt, en of zij hiervoor op de arbeidsmarkt worden gestraft. Het huidige onderzoek is opgezet om meer zicht te krijgen op de mate waarin in het hoger onderwijs aandacht wordt besteed aan het bijbrengen van niet-routinematige vaardigheden. We focussen ons hierbij enkel op bachelor- en masteropleidingen in het hoger beroepsonderwijs (hbo). De beperking tot het hbo heeft twee hoofdredenen. De eerste reden is dat er in het hbo over het algemeen meer aandacht wordt besteed aan vaardigheidsontwikkeling dan in het wetenschappelijk onderwijs (wo), dat doorgaans theoretischer van aard is. De tweede, meer praktische reden is dat de opleidingsprofielen, die als input dienen voor dit onderzoek, in het wo minder systematisch zijn georganiseerd. Dit verschil met het hbo is waarschijnlijk verklaarbaar door de grotere nadruk in het hbo op beroepskwalificaties, waarvoor opleidingen moeten aantonen dat ze die ook aanleren.

Dit onderzoek richt zich op een analyse, door middel van tekstanalyses (text-mining), van de mate waarin de profielen van hbo-opleidingen aandacht besteden aan niet-routinematige vaardigheden. Om dit mogelijk te maken, maken we gebruik van het organisatiemodel van niet routinematige vaardigheden zoals gebruikt door Autor en collega's 
(Autor, Levy, \& Murnane, 2003). Dit model biedt een bruikbaar kader waarmee we (a) routinematige en niet-routinematige vaardigheden van elkaar kunnen onderscheiden, en (b) verschillende hoofd- en subclusters van niet-routinematige vaardigheden kunnen aanwijzen. Op basis van dit organisatiemodel onderzoeken we vervolgens in welke mate niet-routinematige vaardigheden verwerkt zijn in de omschrijvingen van de huidige profielen van hbo-opleidingen door middel van tekstanalyses. Om na te gaan of afgestudeerden aan het einde van hun hbo-opleiding daadwerkelijk over deze vaardigheden beschikken, voeren we tenslotte een analyse op basis van HBO-Monitor data' uit, een jaarlijks onderzoek naar gediplomeerden uit het hbo. Aan de hand van deze stappen kunnen de volgende onderzoeksvragen worden beantwoord:

1. Hoe kunnen niet-routinematige vaardigheden worden gedefinieerd en welk organisatiemodel kan hiervoor het beste worden gebruikt?

2. In welke mate komen niet-routinematige vaardigheden aan bod in de leerdoelen van opleidingen in het hoger beroepsonderwijs?

3. In welke mate beschikken pasafgestudeerden ook daadwerkelijk over deze vaardigheden en worden deze vaardigheden op de arbeidsmarkt vereist?

\subsection{Opbouw rapport}

Dit rapport is als volgt opgebouwd. In hoofdstuk 2 gaan we allereerst dieper in op de betekenis van niet-routinematige vaardigheden en stellen we op basis van het organisatiemodel van Autor en collega's (Autor, Levy, \& Murnane, 2003) een clustering van deze vaardigheden voor. Vervolgens bespreken wij in hoofdstuk 3 de door ons gebruikte data en methode. In hoofdstuk 4 doen we verslag van onze bevindingen ten aanzien van de mate waarin hbo-opleidingen in hun eigen opleidingsprofielen verwijzen naar deze niet-routinematige vaardigheden. In hoofdstuk 5 kijken we vervolgens naar de mate waarin vaardigheden die aan bod komen in hbo-opleidingen, overeenkomen met de daadwerkelijke niet-routinematige vaardigheden van afgestudeerden. In hoofdstuk 6 sluiten we af met de conclusies en samenvatting van dit onderzoek.

1 De HBO-Monitor is een jaarlijks arbeidsmarktonderzoek onder nagenoeg alle afgestudeerden van het Nederlandse hbo. Zie www.hbomonitor.nl voor meer informatie. 



\section{Wat zijn niet-routinematige vaardigheden?}

\subsection{Automatisering en de vraag naar niet-routinematige vaardigheden}

Sinds in de jaren tachtig computers massaal hun intrede deden op de arbeidsmarkt, hebben ze een groot deel van menselijke werkzaamheden overgenomen. Dit betreft vooral routinematige taken van het type if-then die eenvoudig geprogrammeerd kunnen worden en door computers op routinematige wijze kunnen worden uitgevoerd. Niet-routinematige vaardigheden zijn daarentegen vaardigheden die niet makkelijk in codetaal kunnen worden omgezet en onderhevig zijn aan menselijke interpretatie voor een gewenst resultaat (Autor Levy, \& Murnane, 2003). Door de jaren heen zijn er verschillende organisatiemodellen en -kaders voorgesteld waaronder niet-routinematige vaardigheden kunnen worden ondergebracht. Deze kaders variëren met betrekking tot beschrijvingen, gedragsuitingen en scala aan vaardigheden (Borghans, Duckworth, Heckman, \& Ter Weel, 2008). Er worden verschillende termen gebruikt om dit soort vaardigheden aan te duiden, zoals non-cognitieve vaardigheden (Duckworth \& Yeager, 2015), socio-emotionele vaardigheden (OECD, 2018 ab), 21e-eeuwse vaardigheden (Allen \& Van der Velden, 2013; Thijs et al., 2014; World Economic Forum, 2015), levenlang leren vaardigheden (Law, Pelgrum, \& Plomp, 2008), sleutelvaardigheden (European Commission, 2002), kernvaardigheden (Onderwijsraad, 2014), en soft skills (Pang et al., 2019). Deze modellen hebben hun oorsprong in verschillende disciplines, namelijk sociologie, psychologie, onderwijskunde en economie. Voor het voorliggende onderzoek maken wij gebruik van een economische benadering ten aanzien van niet-routinematige vaardigheden en hanteren daarbij het organisatiemodel zoals gebruikt door Autor en collega's (2003). Wij kiezen voor dit model omdat het vaak gebruikt is bij analyses van de veranderende vraag naar vaardigheden op de arbeidsmarkt (meer dan 6.800 citaties in Google Scholar.

\subsection{Naar een organisatiemodel van niet-routinematige vaardigheden}

De economische verklaring voor de veranderende vraag naar vaardigheden is het duidelijkste uitgewerkt in het model van Autor en collega's (Autor, Levy, \& Murnane, 2003, Autor \& Price, 2013). Dit organisatiemodel kwam tot stand op basis van analyses van de dataset Dictionary of Occupational Titles (DOT) en diens opvolger de Occupational Information Network ( $\mathrm{O}^{*} \mathrm{NET}$ ) waarmee het belang van taken en onderliggende vaardigheden per beroep werd geschetst. Op basis hiervan definieerden zij allereerst routinematige taken (met bijbehorende routinematige vaardigheden) als werkactiviteiten 
die dusdanig duidelijk afgebakend zijn dat ze uitgevoerd kunnen worden door een computer of geautomatiseerde machine. Daartegenover zetten zij niet-routinematige taken (met bijbehorende vaardigheden), die complementair zijn aan geautomatiseerde activiteiten, waardoor de vraag ernaar als gevolg van automatisering juist toegenomen is. Vervolgens deelden zij niet-routinematige taken/vaardigheden op in twee brede categorieën: abstracte taken die probleemoplossend vermogen, intuïtie, overtuiging en creativiteit vereisen, en handmatige taken/vaardigheden die situationeel aanpassingsvermogen, visuele- en taalherkenning en persoonlijke interactie en coördinatie vereisen. Abstracte taken werden daarbij onderverdeeld in taken die analytische vaardigheden vereisen, en taken die vooral management- en interpersoonlijke vaardigheden vereisen.

Voor hoger opgeleiden zijn het vooral deze abstracte vaardigheden die van toenemend belang zijn in het licht van de toenemende automatisering van werk. Deze vaardigheden zijn ook terug te vinden in andere bestaande conceptualiseringen van niet-routinematige vaardigheden. Zo worden door het World Economic Forum (2015) 21e-eeuwse vaardigheden nader onderverdeeld in Foundational Literacies (waaronder lees-, reken- en digitale vaardigheden), Competencies (kritisch denken, probleemoplossend vermogen, creativiteit, communicatie en samenwerking) en Character Qualities (nieuwsgierigheid, initiatief nemen, doorzettingsvermogen, aanpassingsvermogen, leiderschapsvaardigheden en sociaal en cultureel bewustzijn). De OESO (2018 $)$ hanteert dan weer een vierdeling qua onderverdeling van vaardigheden, waarbij onderscheid wordt gemaakt tussen Core Subjects (deze set van vaardigheden komt nauw overeen met de Foundational Literacies van het World Economic Forum), Learning and Innovation Skills (kritisch denken, probleemoplossend vermogen, creativiteit, innovatievermogen, communicatievaardigheden en samenwerken); Information, Media and Technology Skills (Informatie- en mediageletterdheid, ICT-geletterdheid); en Life \& Career Skills (aanpassingsvermogen, zelfsturingsvaardigheden, interculturele vaardigheden, leidinggevende vaardigheden, ondernemerschapsvaardigheden en verantwoordelijkheidsbesef).

Uit deze inventarisatie van deze indelingen komt een tamelijk consistent beeld naar voren van de vaardigheden die door experts in de $21^{\mathrm{e}}$ eeuw als relevant worden geacht. Aan de hand hiervan werken wij de tweedeling van abstracte vaardigheden van Autor en collega's (2003) nader uit en komen we tot drie hoofdclusters:

I. Analytische en probleemoplossende vaardigheden, nader onderverdeeld in de subclusters analytische vaardigheden, probleemoplossende vaardigheden, creativiteit, leervermogen en informatiebeheer, en adviserende vaardigheden;

II. Interpersoonlijke vaardigheden, nader onderverdeeld in de subclusters samenwerken, communicatie, leidinggevende vaardigheden, beïnvloedingsvaardigheden en interculturele vaardigheden

III. Zelfsturingsvaardigheden, waaronder zelfregulatievaardigheden, managementvaardigheden, besluitvorming, planningsvaardigheden, ondernemerschapsvaardigheden en ethisch besef. 
Hieraan voegen we bovendien nog een vierde subcluster toe, losjes gebaseerd op de derde en vierde categorieën van de OESO-indeling, namelijk werkgerelateerde vaardigheden. Hieronder vallen vakspecifieke vaardigheden, interdisciplinaire vaardigheden, technologische (ICT) vaardigheden, fysieke vaardigheden en ontwerpvaardigheden. Met uitzondering van fysieke vaardigheden vallen deze vaardigheden niet onder het overkoepelende begrip van niet-routinematige vaardigheden zoals bedoeld door Autor en collega's. Het gaat echter om vaardigheden die in veel van de competentieprofielen van opleidingen worden genoemd, en die ook zeker belangrijk kunnen zijn in een sterk geautomatiseerde economie. Doordat de maatschappij steeds complexer wordt, zijn tegenwoordig de meeste problemen niet meer vanuit één discipline op te lossen. Mensen uit verschillende achtergronden met verschillende expertises moeten daarom meer en meer samenwerken aan duurzame oplossingen voor de toekomst. Vakinhoudelijke deskundigheid speelt hierbij een grote rol. Tabel 2.1 geeft een overzicht van deze vier hoofclusters met bijbehorende subclusters, met voor iedere subcluster een operationele definitie die gebruikt is bij het bepalen van relevante zoektermen.

Tabel 2.1

Overzicht van de hoofd- en subclusters van niet-routinematige vaardigheden

\begin{tabular}{|c|c|}
\hline \multicolumn{2}{|c|}{ Hoofdcluster A: Analytische en probleemoplossende vaardigheden } \\
\hline A1 Analytische vaardigheden: & $\begin{array}{l}\text { Het vermogen om stelselmatig door te dringen tot de essentie van } \\
\text { problemen en situaties, deze te ontleden in verschillende deelaspecten, } \\
\text { en om relaties tussen deze deelaspecten en met andere problemen } \\
\text { en situaties te doorzien. Hierbij hoort onder meer het stelselmatig } \\
\text { analyseren van problemen, begrip kweken, identificeren van kernzaken, } \\
\text { beargumenteerde afwegingen maken op basis van feiten i.p.v. } \\
\text { emotie, systematisch en logisch redeneren, hoofdzaken van bijzaken } \\
\text { onderscheiden, beoordelingsvermogen. }\end{array}$ \\
\hline A2 Probleemoplossend vermogen: & $\begin{array}{l}\text { Het vermogen om problemen en kansen te signaleren, om effectieve } \\
\text { oplossingsstrategieën hiervoor te bedenken en uit te werken, } \\
\text { actieplannen op te stellen en snel, systematisch en effectief toe te } \\
\text { passen om de problemen op te lossen. Deze vaardigheid lijkt veel } \\
\text { overlap te tonen met, en gebruik te maken van, andere vaardigheden } \\
\text { zoals analytische vaardigheden, creativiteit, plannings- en } \\
\text { ondernemerschapsvaardigheden. }\end{array}$ \\
\hline $\mathrm{A}_{3}$ Creativiteit: & $\begin{array}{l}\text { Het vermogen om nieuwe, originele ideeën, oplossingen, producten, } \\
\text { voorstellingen, e.d. te bedenken en tot uitvoering te brengen. Hierbij } \\
\text { kan worden gedacht aan termen als out-of-the-box denken, innovatief, } \\
\text { vernieuwend, iets nieuws creëren, originaliteit, fantasie, verbeelding, } \\
\text { kunstzinnig, vindingrijk, inspiratie. }\end{array}$ \\
\hline
\end{tabular}




\begin{tabular}{|c|c|}
\hline A4 Leervermogen en informatiebeheer: & $\begin{array}{l}\text { a) Leervermogen: het vermogen om nieuwe kennis, informatie, } \\
\text { methoden, technieken, ideeën e.d. op te nemen en te internaliseren } \\
\text { en eigen te maken, en te integreren met al eerder opgedane kennis. } \\
\text { Relevante termen zijn onder andere levenlang leren, loopbaanleren, } \\
\text { opslaan nieuwe informatie, dingen eigen maken, bijleren, updaten van } \\
\text { kennis, reproduceren van feitenkennis. } \\
\text { b) Informatiebeheer: het vermogen om informatie te zoeken, ordenen, } \\
\text { bewerken en systematisch op te slaan. Hierbij kan worden gedacht aan } \\
\text { het identificeren van geschikte informatiebronnen, toepassen van de } \\
\text { benodigde zoekmethoden/technologie, en het selecteren, verwerken } \\
\text { en integreren van gevonden informatie met kennis die al aanwezig is. }\end{array}$ \\
\hline A5 Adviseren: & $\begin{array}{l}\text { Het bijstaan van derden en het vermogen om zich in te leven } \\
\text { in hun problemen en vragen, op basis van kennis, ervaring en } \\
\text { probleemanalyse geschikte en beredeneerde oplossingen te genereren, } \\
\text { en deze duidelijk en effectief aan de doelgroep te communiceren. } \\
\text { Net als probleemoplossende vermogen lijkt deze competentie } \\
\text { tenminste voor een deel gerelateerd/afgeleid te zijn aan/van andere } \\
\text { vaardigheden, zoals analytische vermogen, communicatie en } \\
\text { beïnvloedingsvaardigheden. }\end{array}$ \\
\hline \multicolumn{2}{|c|}{ Hoofdcluster B: Intermenselijke vaardigheden } \\
\hline B1 Samenwerken: & $\begin{array}{l}\text { Het vermogen om effectief met anderen samen te werken met als doel } \\
\text { gemeenschappelijke werkprestaties te leveren die meer zijn dan de } \\
\text { som van de afzonderlijke bijdragen. Relevante termen zijn onder meer } \\
\text { teamwerk, samen tot iets komen, bijdragen aan gezamenlijk resultaat, } \\
\text { gezamenlijke inzet, bijdragen aan een gezamenlijk resultaat door een } \\
\text { optimale afstemming tussen de eigen kwaliteiten en belangen en die } \\
\text { van de groep/ de ander. }\end{array}$ \\
\hline B2 Communicatie: & $\begin{array}{l}\text { Het vermogen om in zowel formele als informele settings informatie } \\
\text { met anderen uit te wisselen, waarbij aan beide kanten goed } \\
\text { wordt begrepen wat er wordt bedoeld. Gedacht kan woorden aan } \\
\text { vaardigheden die in staat stellen informatie over te brengen naar } \\
\text { derden, uitwisseling van informatie, verbinding leggen met derden, } \\
\text { contact houden. In principe is deze competentie erg breed, en omvat } \\
\text { zowel interpersoonlijke informatieoverdracht als "hardere" skills zoals } \\
\text { lees- en schrijfvaardigheden, (buitenlandse) taalvaardigheden en } \\
\text { presentatievaardigheden. Ook dingen zoals het geven van feedback, het } \\
\text { goed kunnen luisteren, rapporten schrijven en interviewvaardigheden } \\
\text { zouden hieronder kunnen vallen. }\end{array}$ \\
\hline B3 Leidinggevende vaardigheden: & $\begin{array}{l}\text { a) Supervisie: Het vermogen om het werk van anderen te plannen, uit } \\
\text { te zetten, aan te voeren, te monitoren en aan te sturen/corrigeren/bij te } \\
\text { sturen om gestelde doelen te bereiken. } \\
\text { b) Motivatie: Het vermogen om anderen te inspireren en aan te sporen } \\
\text { tot betere werkprestaties. }\end{array}$ \\
\hline B4 Beïnvloedingsvaardigheden: & $\begin{array}{l}\text { Het vermogen om anderen van gedachten te doen veranderen en } \\
\text { over te halen tot een bepaald gezichtspunt. Het gaat hierbij om } \\
\text { iemand of iets proberen te veranderen, het aanpassen van andermans } \\
\text { denkbeelden om een doel te bereiken. }\end{array}$ \\
\hline
\end{tabular}


B5 Interculturele vaardigheden:

Hoofdcluster C: Zelfsturingsvaardigheden
C1 Zelfregulatievaardigheden:

Samenwerken met verschillende culturele achtergronden, inleven in andere standpunten vanuit culturele achtergrond, kennis en bewustzijn van andere gewoonten en gebruiken, zien van overeenkomsten en verbanden tussen verschillende gewoonten en gebruiken.

Het vermogen om de eigen werktaken zonder supervisie uit te voeren en waar nodig bij te stellen. Het gaat onder meer om zelfstandigheid, aanpassen van eigen emoties, impulsen en gedragingen om een doel te bereiken.

\begin{tabular}{|c|c|}
\hline C2 Planningsvaardigheden: & $\begin{array}{l}\text { Een gestructureerd plan van aanpak maken, het uittekenen van een } \\
\text { proces om een doel te bereiken, een beredeneerd en concreet overzicht } \\
\text { maken van gewenste doelstellingen en beschikbare middelen, alsmede } \\
\text { een tijdsorde voor verwezenlijking, het proces om tot een plan te } \\
\text { komen, het tijdig uitvoeren van een reeds gemaakt plan. }\end{array}$ \\
\hline C3 Ondernemerschapsvaardigheden: & $\begin{array}{l}\text { a) Vaardigheden die nodig zijn voor het organiseren van arbeid en } \\
\text { kapitaal met het doel producten te maken en/of diensten te verlenen. } \\
\text { b) Het vermogen om productieve en rendabele mogelijkheden voor de } \\
\text { eigen afdeling of organisatie te creëren, signaleren, implementeren en } \\
\text { verkopen. }\end{array}$ \\
\hline$C_{4}$ Ethisch besef: & $\begin{array}{l}\text { Het vermogen om je werk op een eerlijke, integere, verantwoorde en } \\
\text { gewetensvolle manier uit te voeren, rekening houden met de belangen } \\
\text { van anderen en van de bredere maatschappij en wereld. Het gaat hier } \\
\text { om een kritische bezinning over het juist handelen, afwegen van goed } \\
\text { en fout, overzien en verantwoordelijkheid nemen voor de gevolgen van } \\
\text { ondernomen acties en ideeën. }\end{array}$ \\
\hline C5 Managementvaardigheden & $\begin{array}{l}\text { Het vermogen om een proces aan te sturen, en de kwaliteit van het } \\
\text { proces te waarborgen. Denk aan het toezicht houden op de kwaliteit } \\
\text { van het proces, relaties met alle procesbetrokkenen te onderhouden, en } \\
\text { het inschatten van risico's die mogelijk het proces beïnvloeden. }\end{array}$ \\
\hline C6 Besluitvormingsvaardigheden & $\begin{array}{l}\text { Het vermogen om een afweging te maken tussen verschillende opties, } \\
\text { en daaruit onderbouwd een optie te kiezen. Hierbij moet gedacht } \\
\text { worden aan vaardigheden die in staat stellen 1) op systematische wijze } \\
\text { opties te genereren, 2) deze opties te wegen, en 3) te kiezen voor een } \\
\text { optie die de voorkeur geniet. }\end{array}$ \\
\hline \multicolumn{2}{|c|}{ Hoofdcluster D: Werkgerelateerde kennis en vaardigheden } \\
\hline D1 Vakspecifieke kennis en vaardigheden: & $\begin{array}{l}\text { De specifieke kennis en vaardigheden die nodig zijn voor het uitoefenen } \\
\text { van een vak, en het vermogen om deze vaardigheden toe te passen. } \\
\text { Trefwoorden zijn o.a. vakkennis, expertise, mono-disciplinariteit. }\end{array}$ \\
\hline $\begin{array}{l}\text { D2 Interdisciplinaire kennis en } \\
\text { vaardigheden: }\end{array}$ & $\begin{array}{l}\text { Vaardigheden noodzakelijk voor het samenwerken met verschillende } \\
\text { vak-achtergronden, kennis van verschillende werkgebieden, } \\
\text { multidisciplinariteit. }\end{array}$ \\
\hline $\begin{array}{l}\text { D3 Technologische vaardigheden/digitale } \\
\text { geletterdheid: }\end{array}$ & $\begin{array}{l}\text { Het vermogen om productief gebruik te maken van complexe } \\
\text { technologieën. Dit behelst o.m. kennis van hardware en software, } \\
\text { aansturing van mechanische en digitale processen, mediawijsheid, ICT, } \\
\text { computational thinking, zoeken en vinden van juiste informatie. }\end{array}$ \\
\hline
\end{tabular}


D4 Fysieke vaardigheden:

D5 Ontwerpvaardigheden
Het vermogen om taken uit te voeren waarbij specifieke fysieke handelingen nodig zijn, variërend van fijn-motorische handelingen via lichamelijke behendigheid tot het tillen van zware objecten, of een combinatie van deze dingen. Gedacht kan woorden aan kracht, lenigheid, snelheid, uithoudingsvermogen, lichamelijke techniek en vaardigheid, motoriek.

Vaardigheden die in staat stellen vorm te geven aan een oplossing voor een probleem. Dit kan variëren van het ontwikkelen van een fysieke oplossing tot een meer conceptuele oplossing. 


\section{Methode van tekstanalyse}

\subsection{Methodekeuze}

Het doel van het huidige onderzoek is inzicht krijgen in de mate waarin niet-routinematige vaardigheden verwerkt zijn in hbo-profielen. In het voorgaande hoofdstuk is ingegaan op het organisatiemodel voor niet-routinematige vaardigheden dat voor het huidige onderzoek wordt gehanteerd. De volgende stap is het kwantificeren van de mate waarin deze vaardigheden voorkomen in hbo-profielen. Hiervoor maken wij gebruik van een dataset (corpus) van profielbeschrijvingen van hbo-opleidingen, gecombineerd met methoden uit de tekstanalyse. Met andere woorden onze methode bestaat uit het doorzoeken van profielen omschrijvingen aan de hand van betekenisvolle trefwoorden die samenhangen met de omschrijving van niet-routinematige vaardigheden. De methoden lichten wij in de volgende paragrafen nader toe.

\subsection{Databronnen}

Als databronnen voor de huidige analyse maken wij gebruik van profielbeschrijvingen zoals deze te vinden zijn via de website van de Vereniging Hogescholen (https://www. vereniginghogescholen.nl/profielenbank). Voor de lerarenopleidingen verwijst deze website door naar de website '10 voor de Leraar' (https://10voordeleraar.nl/publicaties), waar wij de profielbeschrijvingen voor de eerste- en tweedegraads lerarenopleidingen vandaan hebben gehaald. Beide databronnen geven per CROHO-codez een overzicht van de opleiding. Een voorwaarde voor inclusie in onze dataset is de aanwezigheid van de profielbeschrijvingen in bovenstaande databases. Onze dataset bestaat daarom met name uit profielen van bacheloropleidingen die te vinden zijn in deze databases. Voor het merendeel van de masteropleidingen is echter geen beschrijving beschikbaar in deze databases. Daarom worden slechts enkele masteropleidingen - veelal diegenen gegeven aan meerdere hogescholen - meegenomen, waarvan de beschrijving voor handen is in deze databases. Onze uiteindelijke dataset beslaat daarmee 102 bacheloropleidingen en 21 masteropleidingen. Tabel 3.1 geeft een overzicht van de meegenomen bacheloropleidingen, geordend op HOOP-sector3. Tabel 3.2 geeft een overzicht van de masteropleidingen.

We richten ons in dit onderzoek specifiek op de onderdelen van de profielen die gericht zijn op de beschrijving van de in de opleiding aan bod komende vaardigheden. Per

\footnotetext{
https://www.onderwijsinspectie.nl/onderwijssectoren/hoger-onderwijs/sectoren/indeling-sectoren https://www.onderwijsinspectie.nl/onderwijssectoren/hoger-onderwijs/documenten/publicaties/2017/07/07/indeling-sectoren-hoger-onderwijs
} 
opleiding isoleren wij handmatig dit gedeelte van de profieltekst, en voegen deze tekstbeschrijving toe aan een database. Zo ontstaat een corpus van tekstuele beschrijvingen van de competentieprofielen zoals deze door de respectievelijke opleidingen zelf zijn opgesteld. Deze tekstbeschrijvingen dienen als basis voor het in kaart brengen van de mate waarin niet-routinematige vaardigheden terugkomen in de profielen. Vanaf nu refereren we met profielbeschrijvingen slechts aan dit deel van de tekst dat de vaardigheden beschrijft. 

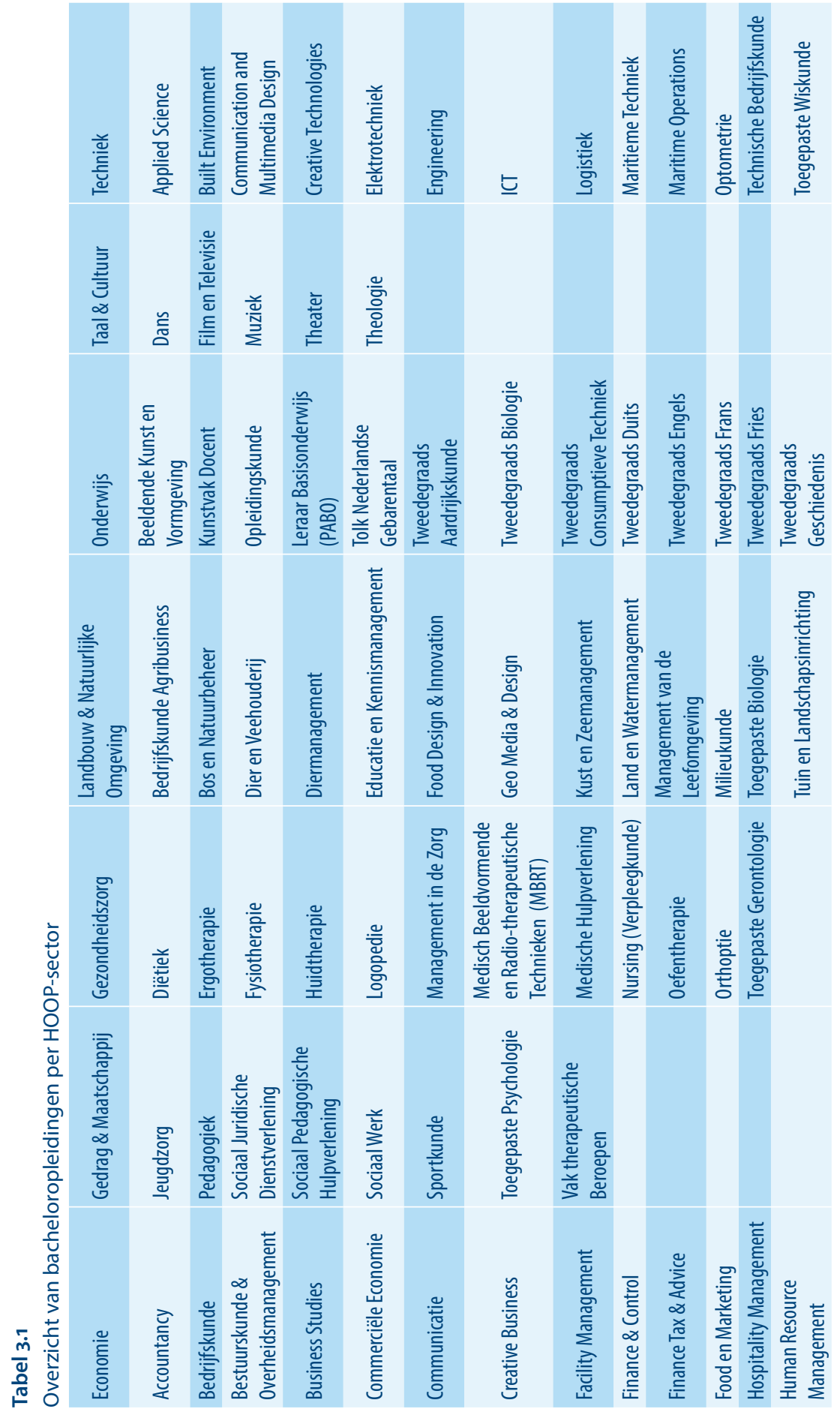


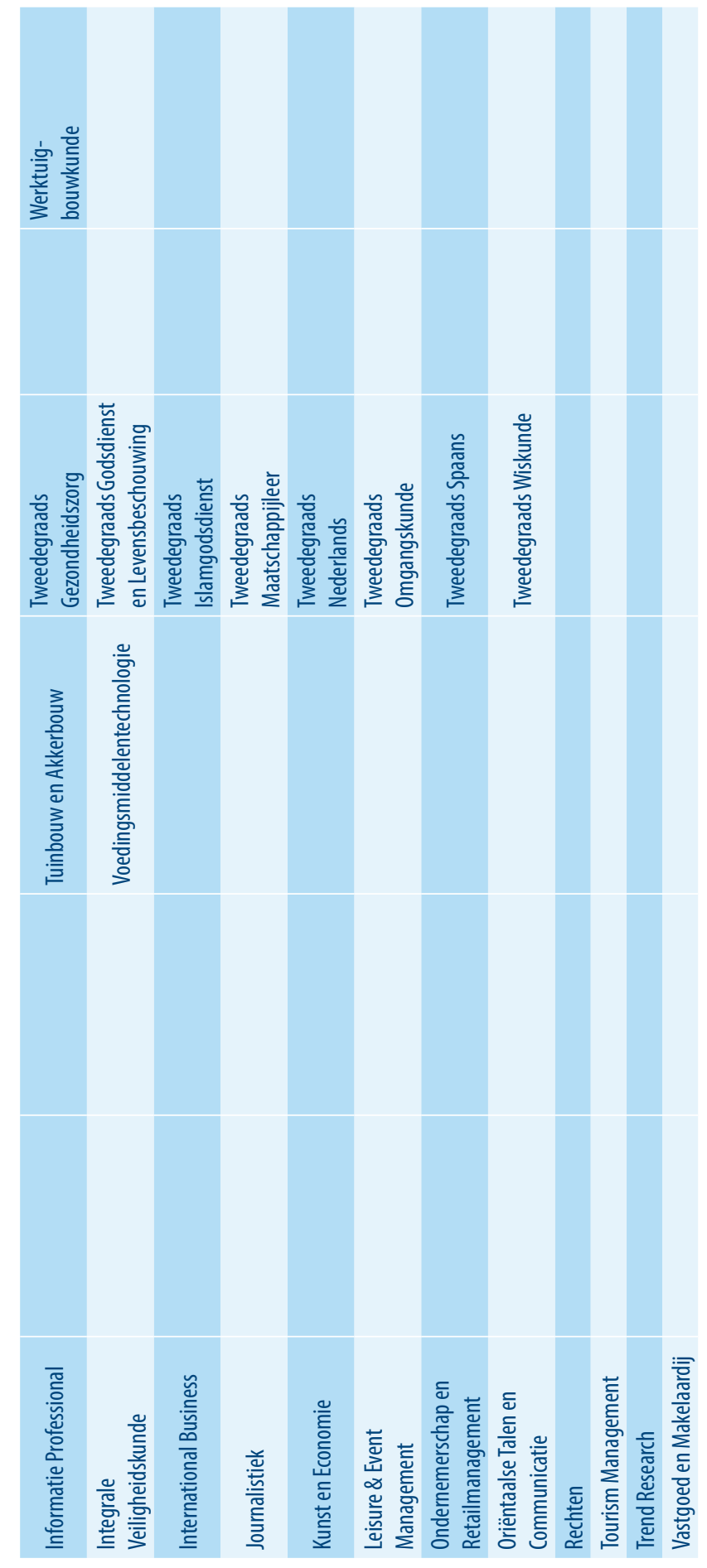




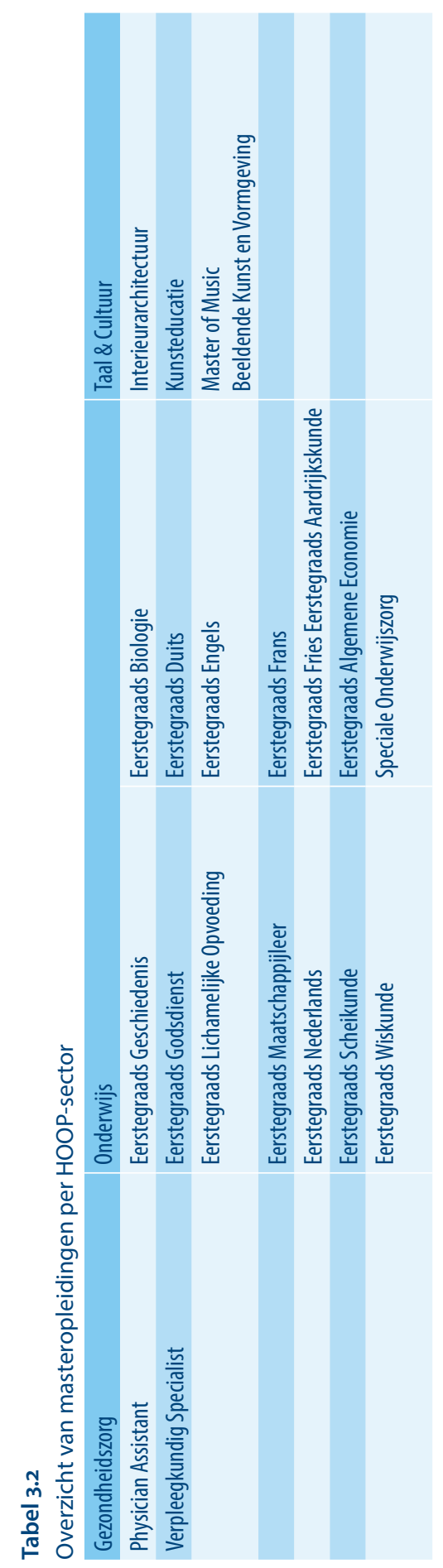




\subsection{De lexicon methode}

Onze dataset beslaat de tekstuele beschrijving van de vaardigheden die worden aangeleerd in elke hbo-opleiding, zoals deze verwoord zijn in de profielbeschrijvingen van de hbo-instellingen zelf. Het is belangrijk op te merken dat vaardigheden waar de hboinstellingen voor opleiden die niet verwoord zijn in de profielbeschrijvingen door ons niet gemeten kunnen worden. Om uit profielbeschrijvingen een maatstaf voor de mate waarin de relevante niet-routinematige vaardigheden voorkomen binnen een opleiding te creëren, is gekozen voor het toepassen van gesuperviseerde tekstanalyse (Hartmann et al., 2019). In een dergelijke analyse wordt een vooraf bepaalde semantische classificatie toegepast op woorden binnen een tekst. Dit in tegenstelling tot een niet-gesuperviseerde methode (bv. topicmodellen, Blei, 2012), waarbij een algoritme zelf de semantische samenhang bepaalt. Gesuperviseerde tekstanalyse methodes worden voor veel doelen gebruikt, met name op het gebied van sentimentanalyse (Pang en Lee. 2008) en emotieanalyse (bv. Berger en Milkman, 2015). In dergelijke analyses wordt aan woorden een vooraf bepaald sentiment (positief, negatief, neutraal) of emotie (blijdschap, verdriet) toegekend. Hierop volgend kan vervolgens de gehele tekst gescoord worden op basis van het/de overheersende sentiment of emotie. In het huidige onderzoek passen we deze methode toe om de mate waarin een bepaalde niet-routinematige competentie, zoals geoperationaliseerd in hoofdstuk 2, voorkomt in een opleiding te kwantificeren.

Dit type tekstanalyse maakt gebruikt van het bag-of-words principe:Tekst wordt gerepresenteerd als een verzameling woorden, en aan individuele woorden wordt een bepaalde waarde (bv. sentiment, emotie) toegedicht, die reflectief is voor de tekst. Een dergelijke analyse negeert de grammaticale samenhang tussen woorden, alsmede de woordvolgorde, maar behoudt de woordfrequentie. Dit kan als beperkend worden ervaren, maar heeft als voordeel dat grote hoeveelheden tekst op eenvoudige wijze gerepresenteerd kunnen worden, en dat op eenvoudige wijze maatstaven ontwikkeld kunnen worden om de tekst als geheel samen te vatten. Dit is in lijn met ons doel binnen dit onderzoek.

Binnen de gesuperviseerde tekstanalysemethoden zijn twee klassen van methodes te onderscheiden: De lexicon methode, en de machine learning methode (Hartmann et al. 2019). Waar bij de eerste methode op basis van reeds bestaande woordenboeken (bv. de Linguistic Inquiry and Word Count (LIWC) lexicon, Pennebaker et al., 2015) de woorden in een tekst worden geclassificeerd, worden bij de machine learning methode op basis van een reeds (handmatig) gelabelde dataset machine learning algoritmes getraind, die de tekst automatisch classificeren (Hartmann et al., 2019). Naarmate de hoeveelheid en frequentie van de te classificeren tekst toeneemt, heeft de machine learning methode de voorkeur, omdat deze het classificatieproces automatiseert, en daardoor sneller en efficiënter veel tekst kan analyseren. 
Voor het huidige onderzoek is gekozen voor een lexicon methode, ondanks de afwezigheid van een bestaand lexicon. De reden hiervoor is de veelheid aan niet-routinematige vaardigheden die wij in hoofdstuk 2 hebben geïdentificeerd, de relatief beperkte omvang van de tekstdataset welke het eenvoudig maakt om teksten in detail te bekijken, en het feit dat wij gebruik maken van een vaste structuur waarin elke tekst geclassificeerd dient te worden, namelijk de verschillende niet-routinematige vaardigheden en de mate waarin daarnaar verwezen wordt in de profielen. Om dit te bereiken hebben wij zelf een lexicon ontwikkeld om niet-routinematige vaardigheden te classificeren binnen een gegeven tekst.

\subsection{Ontwikkeling van het lexicon}

Op een iteratieve wijze hebben wij een lexicon ontwikkeld om niet-routinematige vaardigheden te classificeren. Daarbij hebben wij stappen gevolgd uit eerder werk waarin lexicons zijn ontwikkeld, zoals de eerdergenoemde LIWC (Pennebaker et al., 2015). Specifiek is na een initiële brede zoektocht naar woorden voor het lexicon verdere verfijning aangebracht door gebruik te maken van menselijke codeurs (in casu, leden van het onderzoeksteam).

Het startpunt voor deze ontwikkeling zijn de vier geïdentificeerde competentieclusters (analytische en probleemoplossende vaardigheden, interpersoonlijke vaardigheden, zelfsturingsvaardigheden en werkgerelateerde vaardigheden), en hun onderliggende vaardigheden. De academische literatuur geeft verschillende beschrijvingen van vaardigheden die onder deze competentieclusters vallen (bv. analytisch denken en interpreteren voor de competentie analytische vaardigheden; zie ook de beschrijvingen in Tabel 2.1). Alle geïdentificeerde woorden uit ons organisatiemodel zijn gebruikt als initiële set van woorden voor het lexicon. Waar nodig zijn de woorden uit het Engels naar het Nederlands vertaald, omdat de voertaal van de meeste profielbeschrijvingen Nederlands is.

Om de initiële woordenlijst verder te verfijnen en geschikt te maken voor toepassing binnen het corpus van profielbeschrijvingen, hebben vier leden van het onderzoeksteam beurtelings en handmatig een set van 27,747 woorden doorgenomen. Dit zijn de woorden die overbleven na het schonen van de teksten (zie paragraaf 4.3). Hierbij hebben zij alle kernwoorden die verwezen naar de niet-routinematige vaardigheden uit het gebruikte organisatiemodel (zie hoofdstuk 2) geïsoleerd, en toegewezen aan een specifieke competentie. Waar deze woorden niet voorkwamen in de initiële lexicon, zijn deze toegevoegd nadat een ander lid deze classificatie had gecontroleerd. Op deze wijze is de initiële lexicon verder uitgebreid met additionele woorden die informatie over de vaardigheden bevatten. Uiteindelijk is de volledige lijst nogmaals door alle vier codeurs bekeken en bediscussieerd, om zodoende tot een uiteindelijke toewijzing per woord aan een competentie te komen. 
Het eindproduct van deze uitgebreide validatie-exercitie is een lexicon van 2,695 woorden verspreid over de 21 vaardigheden, waardoor een zo volledig mogelijk beeld ontstaat van woorden die verwijzen naar niet-routinematige vaardigheden in de context van het Nederlandse hbo-onderwijs. Voorbeelden van kernwoorden zijn voor een aantal vaardigheden te vinden in Tabel 2.1. Aan de hand van dit lexicon kan worden onderzocht in welke mate bepaalde vaardigheden genoemd worden in de hbo-profielen.

\subsection{Kwantificeren van niet-routinematige vaardigheden}

Middels het lexicon kunnen alle profielbeschrijvingen worden geclassificeerd op basis van de mate waarin bepaalde vaardigheden voorkomen binnen de tekstuele beschrijving van het profiel. Voordat de beschrijvingen zijn geanalyseerd, zijn de ruwe teksten opgeschoond in lijn met standaard tekstanalyseprocedures (bv. Ludwig et al. 2013; Villaroel Ordenes et al. 2017). Specifiek hebben we de volgende stappen genomen in de analyse: Eerst is de tekst opgebroken in individuele woorden (tokenization), omdat de individuele woorden de basis voor onze analyse vormen. Vervolgens zijn niet-tekstuele elementen, zoals leestekens en cijfers, verwijderd. Verder zijn hoofdletters vervangen door kleine letters, omdat hetzelfde woord anders als twee verschillende woorden wordt gezien door de software (bv. Analytisch en analytisch). Om de tekst te vereenvoudigen zijn veelvoorkomende woorden verwijderd, zoals aanwijzende voornaamwoorden (deze, die), persoonlijke voornaamwoorden (hij, u) en voegwoorden (en, omdat). Al deze stappen zijn uitgevoerd middels functies in de tm bibliotheek in de R-taal (R Core Team 2020). De opgeschoonde beschrijvingen zijn vervolgens gebruikt om middels het lexicon de mate van aanwezigheid van een competentie te berekenen.

Om een kwantitatieve maatstaf voor deze mate te creëren, gebruiken we de frequentie waarin woorden voorkomen, in lijn met voorgaand onderzoek (bv. Ludwig et al. 2013; Villaroel Ordenes et al. 2017). Het onderliggende idee is dat naarmate een opleiding meer aandacht besteedt aan een specifieke competentie, een groter deel van de totale profielbeschrijvingen hiernaar verwijst. Specifiek kwantificeren we de mate waarin een competentie Comp voorkomt in profiel $i$ als volgt:

$$
\operatorname{Comp}_{i}=\frac{\sum_{j=1}^{n} W_{i j}}{N_{i}},
$$

waar $\sum_{j=1}^{n} w_{i j}$ de som van het aantal lexiconwoorden gerelateerd aan een competentie in profielbeschrijvingen $i$ is, en $\mathrm{N}_{\mathrm{i}}$ het totaal aantal woorden in de profielbeschrijvingen. Door te delen door dit aantal woorden wordt gecorrigeerd voor de uiteenlopende lengtes van de profielbeschrijvingen. Deze maatstaf neemt een waarde aan tussen 
o en 1, waarbij waardes dichter bij 1 een hogere score op een bepaalde competentie impliceren. Bijvoorbeeld als 'originaliteit' het enige woord was voor het meten van de subcluster creativiteit (in werkelijkheid zijn er meer woorden die hiervoor zijn gebruikt; zie tabel 2.1), en het wordt 5 keer genoemd in een specifiek hbo-profiel van 100 woorden,

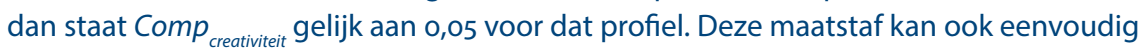
worden geaggregeerd tot het niveau van een competentiecluster door het gemiddelde van de scores van de onderliggende vaardigheden te nemen.

Het gebruik van bovenstaande maatstaf leidt tot het meten van de relatieve intensiteit waarin een bepaalde competentie voorkomt in de beschrijving van een opleiding. Vergelijking van deze maatstaf binnen en tussen opleidingen stelt ons in staat om verschillen in de mate waarin bepaalde niet-routinematige vaardigheden aan bod komen meetbaar te maken. Hogere scores impliceren hierbij een grotere mate van aanwezigheid van een bepaalde competentie. Hier moet wel opgemerkt worden dat de absolute score op zichzelf geen interpretatie heeft. Er kunnen daarom alleen uitspraken in relatieve zin gedaan worden, d.w.z. uitspraken in de lijn van "een opleiding scoort hoger op competentie A dan op competentie B", of "opleiding X scoort hoger op deze competentie dan opleiding Y". Verder stelt het ons ook in staat om deze mate te relateren aan gegevens uit de HBO-Monitor over de mate waarin afgestudeerden deze vaardigheden ervaren.

Ter illustratie hebben wij voor de opleiding ICT de scores per competentie geilllustreerd in Tabel 3.3. Zoals te zien is in deze tabel, scoort ICT vooral hoger op analytische en probleemoplossende vaardigheden, dan op werkgerelateerde vaardigheden en zelfsturingsvaardigheden. De scores op intermenselijke vaardigheden zijn echter nog veel lager. De hoge scores op de eerste competentie worden vooral veroorzaakt doordat ICT aangeeft veel aandacht te besteden aan analytische vaardigheden (zie hiervoor Appendix 3 en 4 voor de scores per subcompetentie). De nadruk die in de profielbeschrijvingen op vakspecifieke, technologische en ontwerpvaardigheden wordt gelegd leidt tot een hoge score op werkgerelateerde vaardigheden, terwijl de nadruk op planningsvaardigheden en ethisch besef in de beschrijving leiden tot een hoge score op het competentiecluster zelfsturingsvaardigheden. Op deze wijze zijn voor elke opleiding in het corpus scores gegenereerd per hoofdcompetentie en subcompetentie.

Tabel 3.3

Voorbeeld van scores per hoofdcompetentie voor de hbo-bacheloropleiding ICT

\begin{tabular}{|c|c|c|c|c|}
\hline & $\begin{array}{c}\text { Analytische en } \\
\text { Probleemoplossende } \\
\text { vaardigheden }\end{array}$ & $\begin{array}{c}\text { Intermenselijke } \\
\text { vaardigheden }\end{array}$ & $\begin{array}{c}\text { Zelfsturingsvaardigheden } \\
\text { ICT }\end{array} \quad \begin{array}{c}\text { Werkgerelateerde } \\
\text { vaardigheden }\end{array}$ \\
\hline $\mathbf{0}$ & 0,067 & 0,046 & 0,054 \\
\hline
\end{tabular}




\subsection{Robuustheid van de maatstaf}

De validiteit van onze maatstaf zou kunnen worden beïnvloed door het feit dat het bagof-words principe dat wij hanteren de woordfrequentie behoudt. Dat wil zeggen dat als eenzelfde woord meermaals voorkomt in een tekst, deze ook meermaals wordt meegeteld in de vaardigheidsscore. Hierdoor zouden opleidingen waarin veelvuldig hetzelfde woord wordt herhaald in de beschrijving mogelijk een hogere score kunnen krijgen dan opleidingen waar slechts eenmaal een woord wordt gebruikt. Om dit te onderzoeken, hebben we als robuustheidstest de maatstaven ook berekend zonder rekening te houden met de frequentie van het woord; d.w.z., als een woord meerdere malen voorkwam in de beschrijving, is deze slechts eenmaal geteld. De Pearson correlatie tussen beide operationalisaties was hoog (.69-. 91), wat laat zien dat het effect van woordfrequentie gering is.

Een andere mogelijke bedreiging voor de validiteit van onze maatstaf hangt samen met de onderliggende databron, namelijk de profielbeschrijvingen zoals die op de website van de Vereniging Hogescholen staan. Gelet op de toenemende belangrijkheid van niet-routinematige vaardigheden in het hoger onderwijs, en het feit dat beschrijvingen niet jaarlijks worden geüpdatet, zou het kunnen dat oudere beschrijvingen stelselmatig lager scoren op vaardigheden dan nieuwere beschrijvingen. Dit blijkt echter niet het geval. Een one-way ANOVA-analyse laat geen significante verschillen zien tussen de verschillende jaren op alle vaardigheidsclusters voor bacheloropleidingen (analytische vaardigheden $\mathrm{F}(16,85)=1,72, p=0,06$; intermenselijke vaardigheden $\mathrm{F}(16,85)=0,703, p=$ 0,78 ; zelfsturingsvaardigheden $\mathrm{F}(16,85)=1,31, p=0,21$; werkgerelateerde vaardigheden $F(16,85)=1,62, p=0,08)$. Voor masteropleidingen vinden we geen verschil op analytische vaardigheden $(F(4,16)=1,803, p=0,18)$ en intermenselijke vaardigheden $(F(4,16)=0,493$, $p=0,74)$, maar wel voor zelfsturingsvaardigheden $(F(4,16)=8,097, p=0,00)$ en werkgerelateerde vaardigheden $(F(4,16)=5,794, p=0,00)$. Deze laatste verschillen komen echter geheel op het conto van de opleiding Verpleegkundig Specialist, waarvan de profielbeschrijvingen uit 2008 komt. Over het algemeen kunnen we dus concluderen dat er geen verschillen tussen oudere en nieuwere competentieprofielen zijn. Hierbij moet worden opgemerkt dat het merendeel van de profielen (65\% van de bacheloropleidingen, $76 \%$ van de masteropleidingen) uit 2017-2019 komt en dus redelijk recent is. 


\section{Resultaten van de tekstanalyse van opleidingsprofielen}

\subsection{Inleiding}

In dit hoofdstuk worden de resultaten van het tekstanalyseonderzoek naar de aanwezigheid van niet-routinematige vaardigheden in de profielen van hbo-opleidingen in Nederland beschreven. Allereerst bespreken wij hierbij de resultaten op het niveau van de HOOP-sector ${ }^{4}$, waarbij wij ingaan op zowel de hoofdclusters van vaardigheden als de vaardigheden per hoofdcluster. Vervolgens vergelijken we de scores voor de grootste bacheloropleidingen per HOOP-sector, en presenteren we ook enkele resultaten voor de onderzochte masteropleidingen. Vanwege de veelheid van resultaten is er voor gekozen niet in te gaan op elke individuele opleiding, maar om een breder beeld te schetsen van de aanwezigheid van vaardigheden in de verschillende sectoren van het hbo-onderwijs in Nederland. In de appendices achterin dit rapport zijn wel alle resultaten per opleiding te vinden.

\subsection{Aanwezigheid van competentieclusters per HOOP-sector - bachelor}

Onze hoofdresultaten met betrekking tot de aanwezigheid van vaardigheden in de profielen zijn samengevat in figuur 4.1 hieronder voor de bacheloropleidingen.

Er zijn duidelijke verschillen te zien tussen sectoren wat betreft de mate van aanwezigheid van elke competentie. Beginnende bij analytische vaardigheden, valt op dat deze relatief meer aanwezig zijn in de profielen van de sectoren economie, landbouw \& natuurlijke omgeving, en techniek. Deze sectoren leunen vanuit hun achtergrond sterker op deze vaardigheden dan bijvoorbeeld gezondheidszorg en taal en cultuur, en dat is terug te zien in de scores voor deze sectoren. Het beeld bij de intermenselijke vaardigheden contrasteert met het voorgaande. Hier scoort met name de gezondheidszorg hoog, maar ook landbouw \& natuurlijke omgeving en onderwijs scoren hier tamelijk hoog. De mensgerichte focus van deze sectoren wordt gereflecteerd in de scores die deze sectoren hebben op intermenselijke vaardigheden. Opleidingen in de sector techniek scoren hier beduidend lager dan de andere sectoren, en geven daarmee aan minder aandacht voor intermenselijke vaardigheden te hebben in hun profielbeschrijvingen dan opleidingen in andere sectoren. 
Figuur 4.1

Scores per competentie voor bacheloropleidingen per HOOP-sector

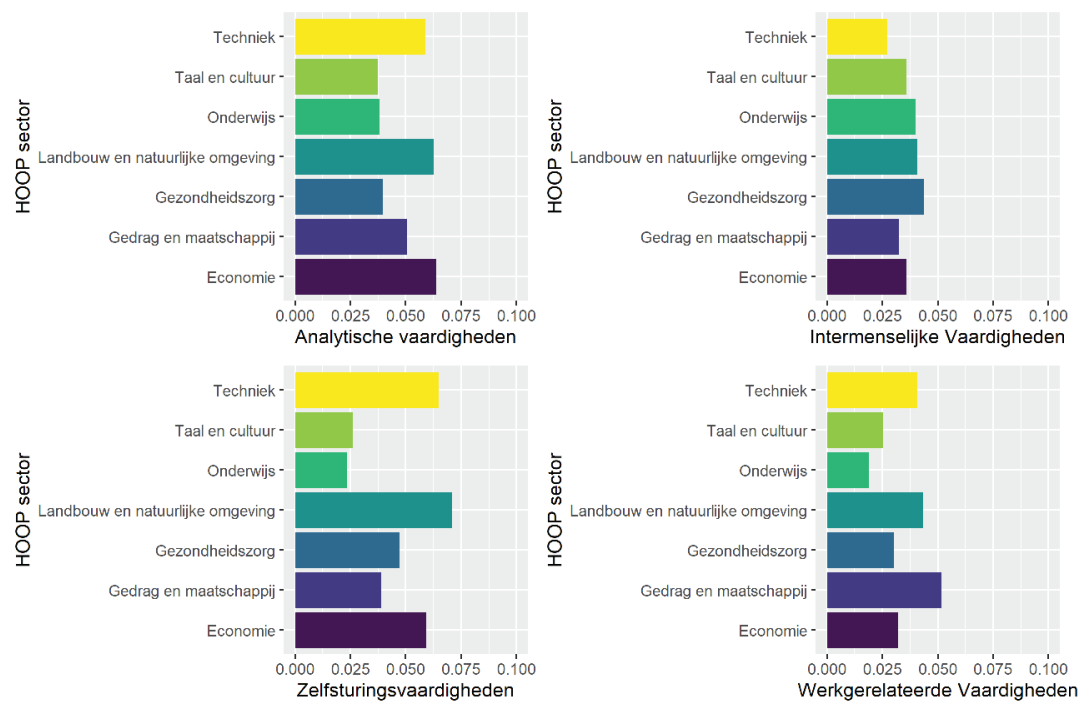

Gedrag \& maatschappij valt hier ook op als uitschieter aangezien ook in de opleidingsprofielen van deze sector weinig gewag wordt gemaakt van intermenselijke vaardigheden. Als we kijken naar de zelfsturingsvaardigheden, zijn er drie sectoren die hier relatief hoog op scoren: techniek, landbouw \& natuurlijke omgeving, en economie. De sectoren taal \& cultuur en onderwijs scoren hier juist relatief laag op. In paragraaf 4.3 gaan we dieper in op deze opvallende uitkomst. Als laatste kijken we naar de werkgerelateerde vaardigheden. Hierbij valt vooral op dat de sector gedrag \& maatschappij, die relatief laag scoort op alle voorgaande competentieclusters, hier juist het hoogst scoort. Hier zou dus sprake kunnen zijn van een sterke aandacht op deze vaardigheden ten koste van andere vaardigheden. Ook techniek en landbouw \& natuurlijke omgeving scoren hier wederom hoog. Opvallend is dat vooral onderwijs en taal \& cultuur hier relatief wat lager scoren. Gegeven de specificiteit van de vaardigheden in dit cluster moet hier wel de kanttekening gemaakt worden dat wij hier kijken naar werkgerelateerde vaardigheden die zich in generieke termen laten vangen; het valt bijvoorbeeld op dat de profielbeschrijvingen in het onderwijs gedetailleerde overzichten bevatten van alle kennisgebieden waarvan docenten op de hoogte moeten zijn bij het afronden van de opleiding. Deze vallen echter buiten het competentieprofiel van deze beschrijvingen, waardoor ze niet zijn meegenomen in onze analyse. Er valt dus niet te concluderen dat sectoren die relatief laag scoren op deze competentie te weinig aandacht aan werkgerelateerde vaardigheden besteden; we richten ons hier specifiek op generieke 
vaardigheden op het gebied van vakspecifieke kennis en vaardigheden, interdisciplinaire kennis en vaardigheden, technologische vaardigheden/digitale geletterdheid en fysieke vaardigheden (zie Tabel 2.1).

\subsection{Aanwezigheid van vaardigheden per HOOP-sector - bachelor}

De voorgaande paragraaf schetste een algemeen beeld van de aanwezigheid van de vier niet-routinematige competentie-hoofdclusters in de zeven HOOP-sectoren. Echter, de vier hoofdclusters bestaan uit meerdere onderliggende vaardigheden. In deze paragraaf gaan we nader in op de verschillen in onderliggende vaardigheden tussen de HOOP-sectoren.

\section{Analytische vaardigheden: vaardigheden per HOOP-sector}

De hoofdcluster analytische vaardigheden bestaat in onze operationalisatie uit vier onderliggende vaardigheden: (1) analytische vaardigheden, (2) creativiteit, (3) leervermogen en informatiebeheer, en (4) probleemoplossend vermogen. Figuur 4.2 hieronder geeft de scores per HOOP-sector. Uit deze figuur wordt allereerst duidelijk dat in alle sectoren opleidingen relatief meer aandacht besteden aan analytische vaardigheden en probleemoplossend vermogen dan aan creativiteit en leervermogen \& informatiebeheer. Vooral dit laatste valt op, om dit de vaardigheid betreft om zelfstandig informatie en kennis op te zoeken en tot zich tot nemen, een vaardigheid die zeer belangrijk wordt geacht in deze veranderende wereld waarin aan de lopende band nieuwe kennis wordt ontwikkeld. Het lijkt er dus op dat er in het algemeen weinig aandacht wordt besteed aan het vermogen om zelfstandig tot kennisopname te komen. Wat betreft analytische vaardigheden zelf, zijn het vooral techniek, onderwijs en economie die als sectoren hoog scoren. Waar dit bij techniek en onderwijs voortvloeit uit de aard van het vakgebied zelf, is dit voor het onderwijs met zijn diversiteit aan opleidingen moeilijker terug te voeren. De sectoren gezondheidszorg en gedrag \& maatschappij scoren hier relatief wat lager, alhoewel alle sectoren zoals gezegd relatief hoog op deze subcompetentie scoren vergeleken met de andere subvaardigheden.

Creativiteit komt vooral aan bod in economische opleidingen, voornamelijk de bedrijfskundige opleidingen gericht op innovatie en ondernemerschap. Ook de sectoren landbouw \& natuurlijke omgeving (vanwege de focus op ondernemerschap) en taal en cultuur (vanwege de aanwezigheid van op schepping gerichte opleidingen zoals dans, muziek en theater) scoren relatief hoog op creativiteit. De sector onderwijs scoort op dit vlak het laagste van alle sectoren, vermoedelijk door de focus op het eigen maken van vastomlijnde onderwijsprofielen. Zoals gezegd zijn ook de scores op de subcompetentie leervermogen \& informatiebeheer relatief lager vergeleken met de andere subvaardigheden. De sector onderwijs scoort hier relatief nog het hoogste, voornamelijk doordat veel onderwijsopleidingen het belang van het bijhouden van de vakkennis benadrukken in hun profielen. De verschillen tussen de andere sectoren zijn gering. 


\section{Figuur 4.2}

Scores per competentie op analytische vaardigheden voor bacheloropleidingen per HOOPsector

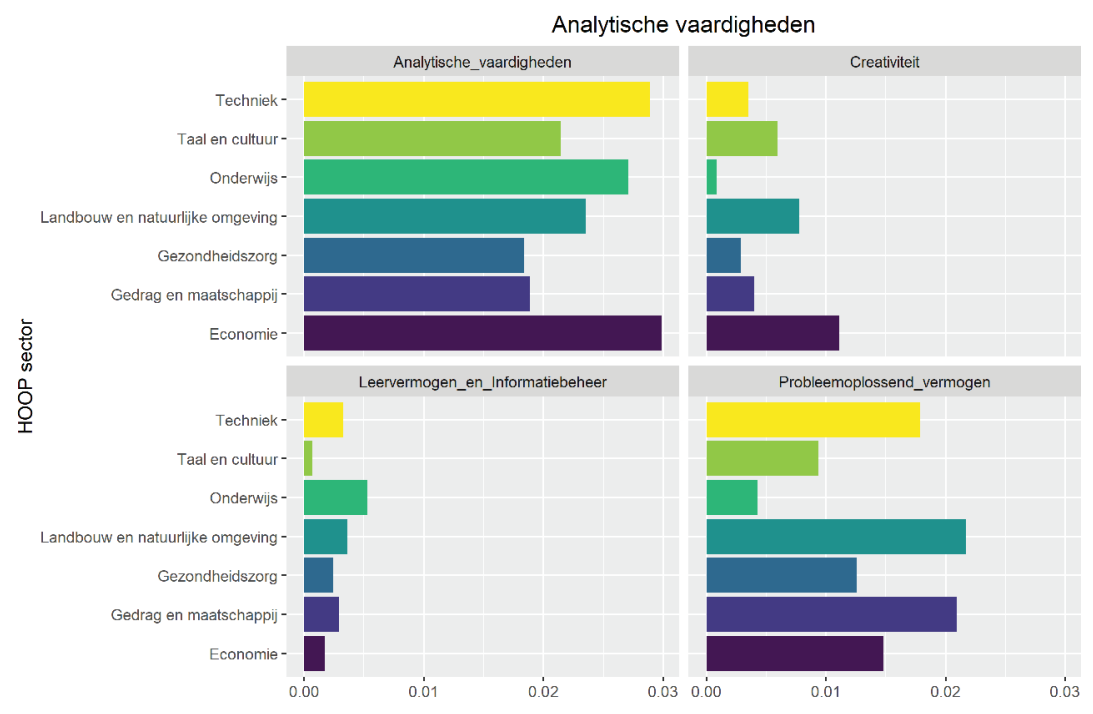

De laatste subcompetentie die onder het hoofdcluster analytische vaardigheden valt is probleemoplossend vermogen, waaronder ook de onderzoeksvaardigheden vallen. Landbouw \& natuurlijke omgeving en gedrag \& maatschappij scoren hier hoog, alsmede de sector techniek. Dit zijn in het algemeen opleidingen die het doen van onderzoek naar en het analyseren van problemen benadrukken in hun profielen, in overeenstemming met de aard van deze opleidingen. Opvallend is dat onderwijsopleidingen dit aspect minder lijken te benadrukken in hun opleidingsprofielen. Wellicht kan dit worden verklaard vanuit het idee dat deze opleidingen zich vooral richten op het aanleren van dergelijke vaardigheden ten behoeve van het onderwijs geven, en niet zozeer het vermogen van deze studenten om zelfstandig onderzoek uit te voeren.

\section{Intermenselijke vaardigheden: vaardigheden per HOOP-sector}

Intermenselijke vaardigheden bestaat in onze operationalisatie uit zes verschillende subvaardigheden: (1) adviseren, (2) beïnvloedingsvaardigheden, (3) communicatie, (4) interculturele vaardigheden, (5) leidinggevende vaardigheden, en (6) samenwerken. Figuur 4.3 geeft de scores per HOOP-sector weer.

De subcompetentie communicatie valt in deze categorie als eerste op, vanwege de hoge mate waarin alle sectoren aandacht besteden aan deze competentie in de beschrijving van hun profielen. Alleen de sectoren techniek en gedrag \& maatschappij besteden iets minder aandacht hieraan, maar vergeleken met de andere vaardigheden kunnen we concluderen dat communicatie de belangrijkste intermenselijke vaardigheid is waaraan 
in het hbo aandacht wordt besteed. Deze competentie omvat velerlei communicatievormen (spreken, schrijven, discussiëren, luisteren), wat illustreert dat opleidingen veel nadruk leggen op de verschillende wijzen waarop studenten zich kunnen uiten en in contact met anderen kunnen treden.

Twee andere vaardigheden waar in de meeste sectoren veel aandacht aan wordt besteed, zijn leidinggevende vaardigheden en samenwerken. Met betrekking tot leidinggevende vaardigheden zien we een redelijk gelijkmatige spreiding van de mate waarin deze competentie wordt ontwikkeld. Alleen de sector economie scoort hier wat lager. Onderwijs en gezondheidszorg scoren juist hoger op de competentie, vermoedelijk vanwege de focus op het begeleiden van leerlingen (onderwijs) danwel het verantwoordelijkheid nemen voor zorgprocessen (gezondheidszorg). Gezondheidszorg scoort ook het hoogst op samenwerken, wat gedreven wordt door de hoge mate van specialisatie binnen deze sector, en de noodzaak om daardoor effectief samen te werken met verschillende specialisaties. Ook binnen de sectoren landbouw \& natuurlijke omgeving en taal \& cultuur zien we dat samenwerken relatief meer aan bod komt dan in andere sectoren.

De subvaardigheden adviseren en beïnvloedingsvaardigheden komen ook geregeld voor binnen sectoren, maar in mindere mate dan de voorgaande vaardigheden. De adviserende competentie komt vooral naar voren in de sectoren economie, landbouw \& natuurlijke omgeving, en techniek. Deze sectoren omvatten bij uitstek opleidingen die gericht zijn op het ondersteunen van (bedrijfs-)processen, waarin het geven van advies centraal staat. Het valt verder op dat binnen de sector taal \& cultuur bij geen enkele opleiding aandacht aan deze competentie wordt besteed. Aandacht voor beïnvloedingsvaardigheden vinden we dan weer vooral binnen de sector gedrag \& maatschappij, waarbinnen opleidingen in het juridische- en zorgdomein die gericht zijn op 'het meekrijgen' en het overtuigen van cliënten in bepaalde processen. Ten slotte valt op dat interculturele vaardigheden, gericht op het samenwerken in cultureel diverse omgevingen, in alle sectoren relatief weinig aan bod komt. Sterker nog, binnen de sectoren gedrag \& maatschappij en gezondheidszorg kon zelfs geen opleiding worden gevonden die aangeeft hier aandacht aan te besteden. Dit is een merkwaardige bevinding die overigens niet betekent dat opleidingen in die sectoren nietsdoen aan interculturele vaardigheden, maar dat zij hier geen expliciete aandacht aan besteden in de beschrijving van hun profielen. Ook de sectoren landbouw \& natuurlijke omgeving en techniek scoren laag op deze competentie. De sector taal \& cultuur scoort relatief het hoogst op deze competentie, welke in onze studie diverse kunst- en mediarichtingen en theologie omvat. Over het algemeen valt echter te zeggen dat vergeleken met de andere vaardigheden in deze categorie, de aandacht voor interculturele vaardigheden relatief het laagste is. 


\section{Figuur 4.3}

Scores per subcompetentie op intermenselijke vaardigheden voor bacheloropleidingen per HOOP-sector

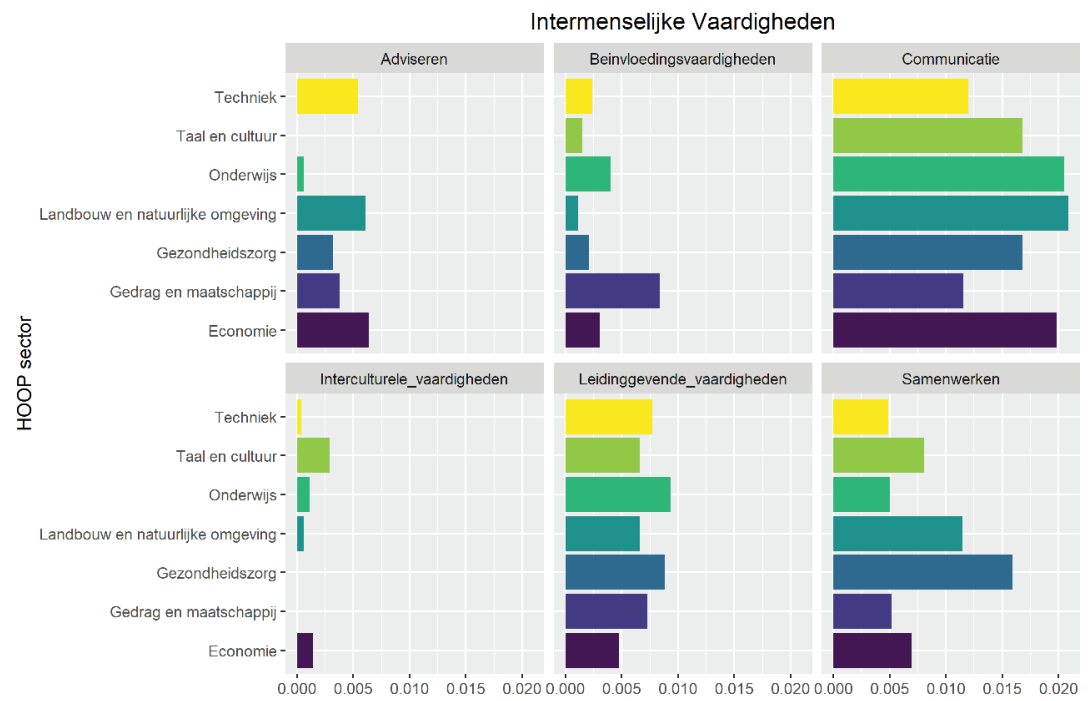

\section{Zelfsturingsvaardigheden: subvaardigheden per HOOP-sector}

Zelfsturingsvaardigheden bestaat in onze operationalisatie uit zes verschillende vaardigheden: (1) besluitvormingsvaardigheden, (2) ethisch besef, (3) managementvaardigheden, (4) ondernemerschapsvaardigheden, (5) planningsvaardigheden, en (6) zelfregulatievaardigheden. Figuur 4.4 geeft de scores per HOOP-sector weer.

In deze categorie zijn het vooral de planningsvaardigheden waaraan binnen de verschillende sectoren veel aandacht wordt besteed. Vooral binnen opleidingen in de sectoren landbouw \& natuurlijke omgeving en techniek zijn de scores hoog. Dit zijn veelal opleidingen die opleiden tot beroepen waarbij veel op projectbasis wordt gewerkt. Hiervoor is het hebben van planningsvaardigheden uiteraard van belang. Onderwijs scoort hier relatief lager dan de andere sectoren. Een andere subcompetentie waar opleidingen binnen sectoren relatief hoog op scoren is ethisch besef. Wederom zijn voor de sectoren landbouw \& natuurlijke omgeving en techniek de scores hoog, maar ook binnen de andere sectoren zien we hoge scores voor het vermogen om op integere en verantwoorde wijze een beroep uit te oefenen. Alleen de sector taal en cultuur scoort hier lager dan andere sectoren, maar we zien ook dat in alle sectoren ethisch besef in de profielen vertegenwoordigd is. De andere vier vaardigheden komen minder frequent aan bod. Wat betreft besluitvormingsvaardigheden scoren vooral de sectoren economie, 
landbouw \& natuurlijke omgeving, en techniek relatief hoog. Dit is te verklaren door de grote hoeveelheid werk op projectbasis, waar naast planning ook het nemen van besluiten centraal staat. De sector taal en cultuur scoort hier aanmerkelijk lager dan de andere sectoren. Hetzelfde patroon qua sectoren zien we ook terug bij managementvaardigheden. Ook hier speelt het project-gebaseerde werk een grote rol in de aanwezigheid van deze competentie binnen deze sectoren. Opvallend hier is ook dat bij geen enkele opleiding in de sector taal en cultuur deze vaardigheid is beschreven.

Ondernemerschapsvaardigheden komen het vaakst voor bij opleidingen in de sector economie, wat een direct uitvloeisel is van het type opleidingen dat onder deze sector valt. Ook in de sectoren techniek en landbouw \& natuurlijke omgeving is er in hogere mate aandacht voor deze competentie dan in andere sectoren. Bovendien wordt er in elke sector wel in enige mate aandacht geschonken aan (een vorm van) ondernemerschapsvaardigheden. Als laatste komen de zelfregulatievaardigheden aan bod, oftewel het vermogen om zelfstandig taken uit te voeren. De opleidingen in de sector economie scoren hier hoger dan de andere sectoren, waarbij deze andere sectoren in ongeveer dezelfde mate aandacht zeggen te geven aan deze competentie.

\section{Figuur 4.4}

Scores per competentie op zelfsturingsvaardigheden voor bacheloropleidingen per HOOPsector

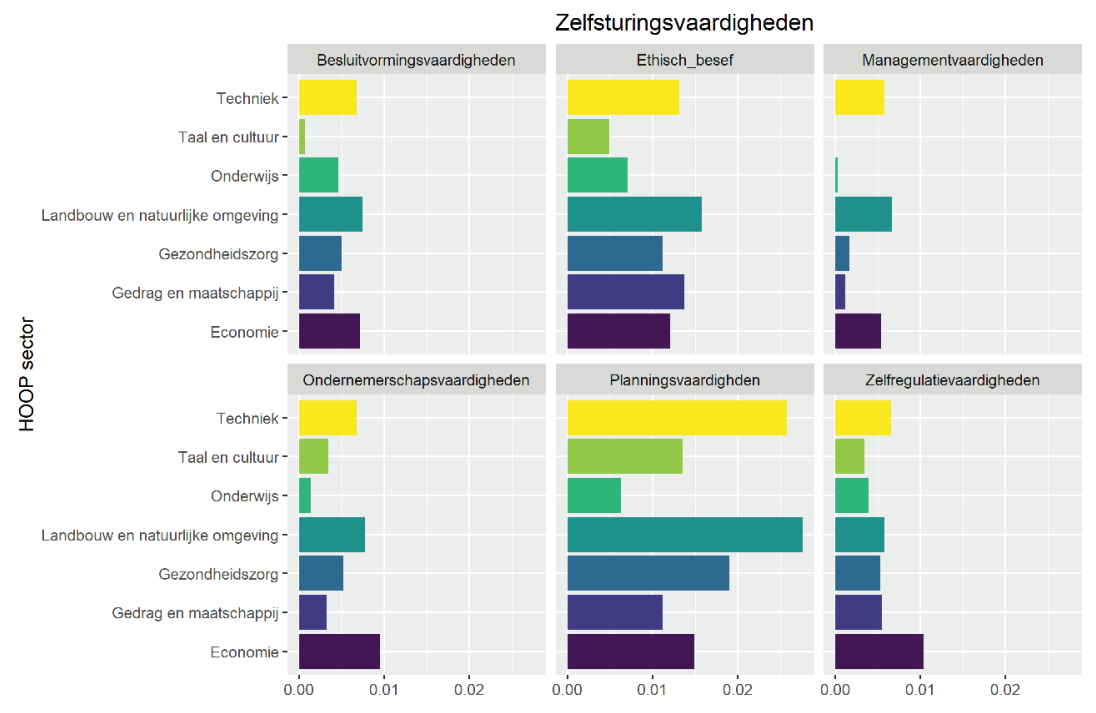

Werkgerelateerde vaardigheden: vaardigheden per HOOP-sector

Werkgerelateerde vaardigheden bestaan in onze operationalisatie uit vijf verschillende subvaardigheden: (1) fysieke vaardigheden, (2) interdisciplinaire vaardigheden, (3) 
ontwerpvaardigheden, (4) technologische vaardigheden, en (5) vakspecifieke vaardigheden Figuur 4.5 geeft de scores per HOOP-sector.

Op het vlak van werkgerelateerde vaardigheden zijn er twee vaardigheden die er in het algemeen uitspringen qua aanwezigheid in de profielen: de vakspecifieke vaardigheden en de ontwerpvaardigheden. Bij de vakspecifieke vaardigheden valt het op dat de sector gedrag en maatschappij hier het hoogste scoort, terwijl deze sector op andere vaardigheden juist gemiddeld of lager scoort. Een verklaring zou kunnen zijn dat opleidingen in deze sector juist veel aandacht besteden aan vakgerelateerde vaardigheden ten koste van andere vaardigheden binnen hun profiel. Anderzijds zou een verklaring ook gezocht kunnen worden in de opbouw van de competentieprofielen zelf, waarin wellicht is gekozen om de vakspecifieke vaardigheden meer te benadrukken dan de andere vaardigheden die ontwikkeld worden. Ontwerpvaardigheden worden het meest gevonden bij de sectoren techniek en landbouw \& natuurlijke omgeving. Dit zijn tevens de sectoren waaronder opleidingen vallen die sterk geassocieerd worden met het ontwerpen van bv. machines, maar ook architectonische ontwerpen vallen hieronder

\section{Figuur 4.5}

Scores per competentie op werkgerelateerde vaardigheden voor bacheloropleidingen per HOOP-sector

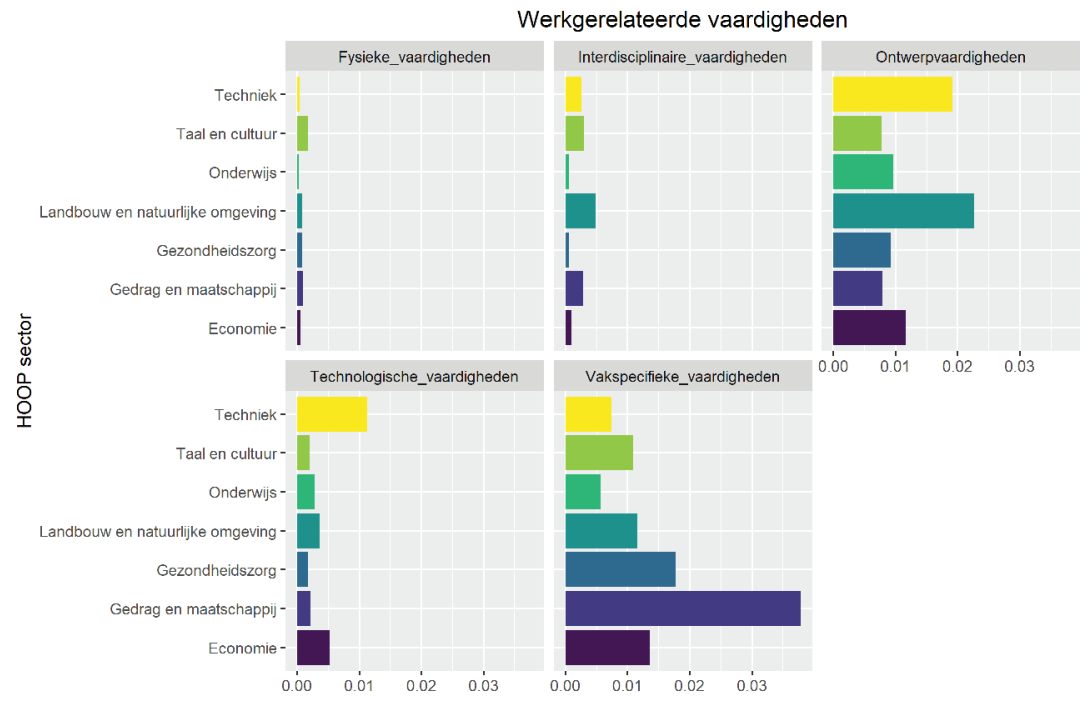

Drie andere subvaardigheden zijn in mindere mate aanwezig in de profielen. Technologische vaardigheden worden in enige mate in elke sector wel besproken, maar alleen in de sector techniek zien we een echt hoge score. Dit is niet verrassend, aange- 
zien ICT- en technische de basis vormen van technische opleidingen. Samenwerken met andere disciplines, gevat onder de subcompetentie interdisciplinaire vaardigheden, komt in alle sectoren in enige mate voor, maar de scores zijn aanmerkelijk lager dan van de andere vaardigheden. De focus in veel profielen lijkt dus te liggen op de eigen discipline (bijvoorbeeld samengevat in de vakspecifieke vaardigheden), en van vaardigheden om samen te werken met andere disciplines lijkt minder sprake te zijn. Tenslotte zien we ook lage scores voor alle sectoren aangaande fysieke vaardigheden. Gegeven het type banen waarvoor de onderzochte hbo-studies opleiden, is het niet opvallend dat de nadruk meer op niet-fysieke dan op fysieke vaardigheden ligt. De hoge scores op de andere vaardigheden besproken in deze en vorige secties bevestigt dit beeld.

\subsection{Aanwezigheid van vaardigheden per opleiding - bachelor}

In de voorgaande paragrafen hebben we op HOOP-sectorniveau de aanwezigheid van vaardigheden besproken. Om ook enkele verschillen tussen opleidingen te belichten, gaan we in deze paragraaf dieper in op competentieverschillen tussen opleidingen. Om de resultaten overzichtelijk te houden, is gekozen om de grootste opleidingen per HOOP-sector qua studentaantallen mee te nemen. Figuur 4.6 geeft een overzicht van de scores per opleiding op competentieclusterniveau.

Het beeld dat in paragraaf 4.1 werd geschetst wat betreft de analytische vaardigheden wordt bevestigd als we kijken naar de grootste opleidingen binnen de sectoren. Binnen de sector techniek valt vooral de opleiding Communication and Multimedia Design op als opleiding die hoog scoort, binnen de sector economie zijn het Commerciële Economie en Rechten die hoog scoren, en Toegepaste Biologie scoort hoog op analytische vaardigheden binnen de sector landbouw en natuurlijke omgeving. Maar ook binnen sectoren die gemiddeld lager scoren op deze competentie zijn er opleidingen die relatief goed scoren ten opzichte van andere opleidingen. Ergotherapie binnen de sector gezondheidszorg scoort bijvoorbeeld aanmerkelijk hoger dan andere opleidingen binnen deze sector, en is op dit competentiecluster vergelijkbaar met opleidingen binnen de sectoren economie, techniek en landbouw \& natuurlijke omgeving. Het is dus niet gezegd dat elke opleiding per se laag scoort op een competentiecluster, maar we zien ook duidelijke verschillen tussen opleidingen binnen een sector.

Opleidingen binnen de gezondheidszorg, met name Logopedie en Diëtiek, scoren over het algemeen erg hoog op intermenselijke vaardigheden. Diermanagement is binnen de sector landbouw en natuurlijke omgeving een opleiding die erg hoog scoort op dit competentiecluster. De andere opleidingen scoren relatief op hetzelfde niveau, met als uitzonderingen ICT en Werktuigbouwkunde binnen de sector techniek. Binnen deze twee opleidingen is er amper aandacht voor intermenselijke vaardigheden. Dit, terwijl deze opleidingen op de andere competentieclusters gemiddeld tot bovengemiddeld scoren, en ook andere opleidingen binnen de sector techniek hier wel in lijn met de 
andere opleidingen scoren. Dit kan een indicatie zijn voor een lacune in deze opleidingsprofielen.

\section{Figuur 4.6}

Scores per competentiecluster voor de grootste opleidingen per HOOP-sector
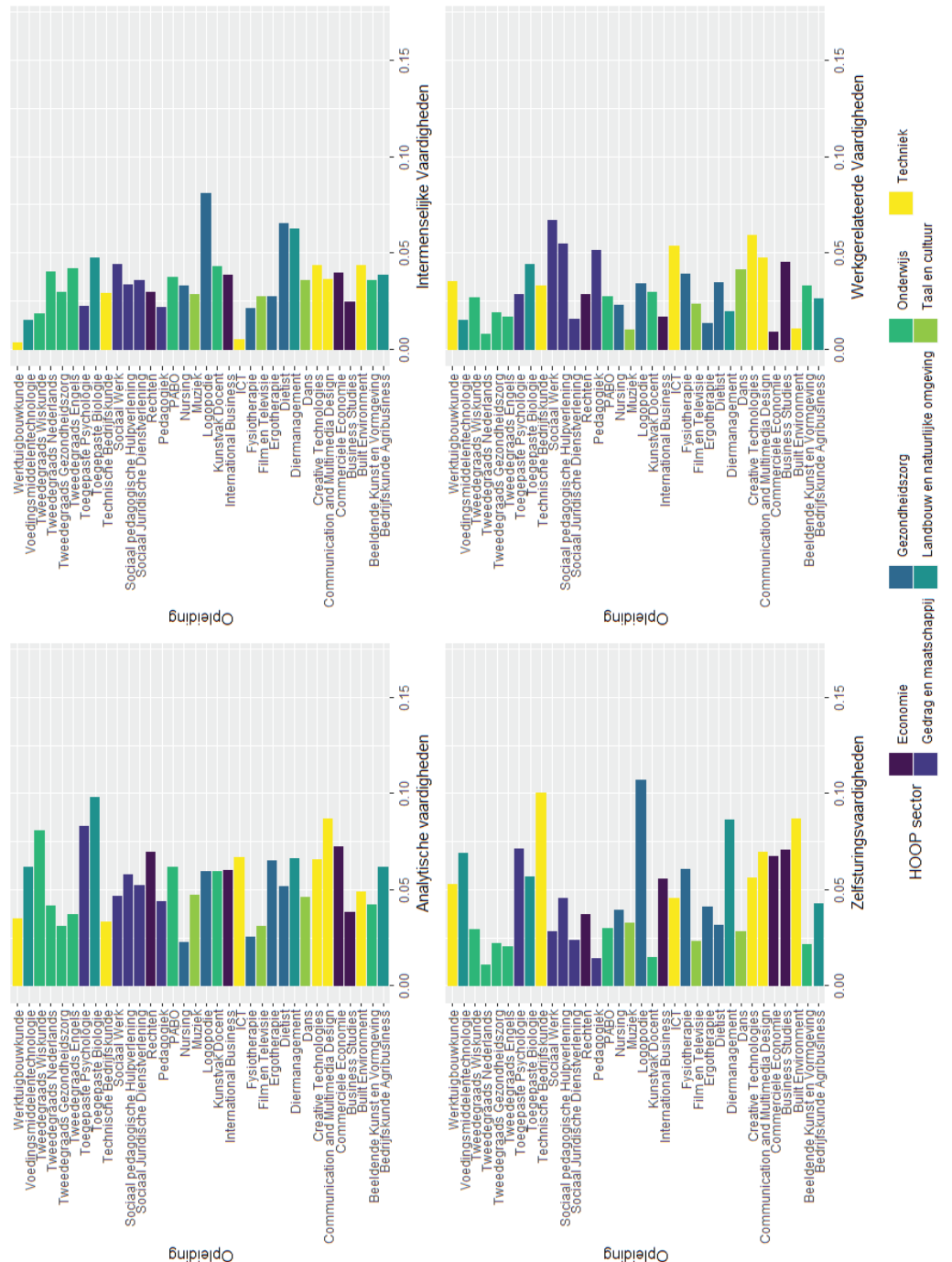

Bij het cluster zelfsturingsvaardigheden zijn er vier opleidingen die eruit springen qua aandacht voor deze vaardigheden: Built Environment en Technische Bedrijfskunde binnen de sector techniek, Logopedie binnen de sector gezondheidszorg, en Diermanagement binnen de sector landbouw en natuurlijke omgeving. Binnen de sector gedrag en maatschappij zien we grote verschillen op dit cluster: Waar Toegepaste Psychologie als een van 
de hoogste opleidingen scoort, scoren de andere opleidingen aanmerkelijk lager. Ter vergelijking, binnen de sector techniek scoren alle opleidingen erg hoog op dit cluster. Als laatste valt op dat alle opleidingen binnen de sectoren onderwijs en taal \& cultuur onverdeeld lager scoren op dit cluster. Het beeld dat in paragraaf 4.1 werd beschreven aangaande werkgerelateerde vaardigheden wordt in dit overzicht verder bevestigd. Opleidingen in de sector gedrag en maatschappij scoren hier in de breedte als hoogste, met alleen Sociaal-Juridische Dienstverlening als uitbijter aan de onderkant. Ook opleidingen in de sector Techniek scoren hoog, maar Built Environment in deze sector behoort juist tot de opleidingen met de laagste scores. Waar taal \& cultuur en onderwijs als sector relatief laag scoren, vallen binnen deze sectoren respectievelijk de opleidingen Dans en Beeldende Kunst en Vormgeving op, die juist als een van de hoogste opleidingen scoren. In het algemeen valt voor dit competentiecluster te zeggen dat de mate waarin werkgerelateerde vaardigheden aan bod komen in de competentieprofielen van profielen sterk varieert zowel tussen opleidingen als tussen sectoren. Een mogelijke oorzaak is het verschil in opbouw van de verschillende competentieprofielen, waarbij sommige opleidingen binnen een sector ervoor kiezen diep in te gaan op de opleidingsspecifieke vaardigheden, terwijl andere opleidingen kiezen voor een meer globaal overzicht van kernvaardigheden, zonder deze specifiek uit te werken voor de opleiding.

\subsection{Aanwezigheid van vaardigheden per opleiding - master}

Vooralsnog zijn enkel de resultaten voor hbo-bacheloropleidingen besproken waarvan wij de opleidingsprofielen konden vinden. Er zijn in dit onderzoek echter ook alle hbomasteropleidingen meegenomen waarvan wij de opleidingsprofielen konden achterhalen. De resultaten van deze kleine groep masteropleidingen bespreken we in deze paragraaf. Wij hebben ervoor gekozen deze opleidingen slechts in het algemeen te bespreken, en geen uitspraken te doen op HOOP-sector of individueel niveau vanwege het kleine aantal masteropleidingen dat is meegenomen. In Figuur 4.7 presenteren wij de scores per masteropleiding op de vier hoofdvaardigheden. Deze figuur bevat ook de score voor de corresponderende bacheloropleiding(en) om de vergelijking tussen master en overeenkomstige bacheloropleidingen mogelijk te maken.

Masteropleidingen onderscheiden zich vooral door hun grote aandacht voor analytische vaardigheden. Niet alleen gaat in masteropleidingen relatief de meeste aandacht naar dit vaardighedencluster uit, er wordt vaak ook beduidend meer aandacht aan besteed dan in de corresponderende bacheloropleidingen; met name bij de onderwijsopleidingen. Het meer specialistische karakter van masteropleidingen wordt dus ook gereflecteerd in de onderliggende vaardigheden die worden aangeleerd. Intermenselijke vaardigheden blijken daarnaast ook een relatief belangrijke rol te spelen in masteropleidingen. Hier valt echter juist op dat de nadruk hierop vaak minder sterk is dan in de corresponderende bacheloropleiding(en). De basis voor dit competentiecluster lijkt dus vaker in de bachelor te worden gelegd, maar masteropleidingen besteden hier zeker ook in ruime mate aandacht aan. Zelfsturings- en werkgerelateerde vaardigheden komen 
in mindere mate aan bod in masteropleidingen in vergelijking met de voorgaande competentieclusters. Verder valt op dat de mate waarin dit vaardighedencluster aan bod komt, redelijk in overeenstemming is met de corresponderende bacheloropleidingen. Samenvattend valt te zeggen dat masteropleidingen vooral meer aandacht besteden aan analytische vaardigheden, terwijl ze in dezelfde mate als in de corresponderende bacheloropleiding(en) aandacht besteden aan zelfsturings- en werkgerelateerde vaardigheden. Dit gaat gepaard met een verminderde aandacht voor intermenselijke vaardigheden ten opzichte van de bacheloropleidingen.

\subsection{Samenhang van vaardigheden}

In de voorgaande paragrafen is vooral gekeken naar de mate waarin bepaalde sectoren/ opleidingen aandacht besteden aan verschillende vaardigheden. Vaardigheden worden echter niet alleen aangeleerd in isolatie, maar ook in samenhang met elkaar. In deze paragraaf onderzoeken we daarom ook of bepaalde vaardigheden binnen een opleiding vaker samen voorkomen; d.w.z., of wanneer een opleiding hoog scoort op een bepaalde competentie, deze opleiding ook op een andere competentie hoog scoort. Hiervoor is in Figuur 4.8 een correlatietabel weergegeven tussen de verschillende vaardigheden. Waardes dichter bij 1 geven vaardigheden aan die vaker gezamenlijk voorkomen, terwijl waardes dichter bij -1 vaardigheden aangeven die juist elkaar uitsluiten; waardes rond o geven vaardigheden aan die niet in gezamenlijkheid voorkomen. Wij beperken ons hier tot de bacheloropleidingen, gegeven de grotere diversiteit van deze opleidingen in onze dataset.

Er is een aantal samenhangende vaardigheden te vinden op basis van deze tabel. Ten eerste zien we dat managementvaardigheden, planningsvaardigheden en adviseren sterk met elkaar samenhangen. Dit geeft aan dat er een aantal opleidingen is dat veel aandacht geeft aan deze vaardigheden, met name in de sectoren economie en landbouw \& natuurlijke omgeving zoals duidelijk is geworden in voorgaande paragrafen. Een tweede cluster van samenhangende vaardigheden zijn die van ondernemerschapsvaardigheden, ontwerpvaardigheden, creativiteit, planningsvaardigheden, en interdisciplinaire vaardigheden. Hier zijn het met name opleidingen in de sectoren taal \& cultuur en techniek die een combinatie van deze vaardigheden aanbieden. Hieruit kunnen we concluderen dat deze opleidingen zich niet alleen richten op het ontwerpproces zelf, maar daarbij ook aandacht besteden aan samenwerking met andere disciplines. Ook wordt aandacht geschonken aan het in de markt zetten van ideeën.

Probleemoplossend vermogen en ethisch besef komen ook veelvuldig samen voor. Dit vloeit voort uit de onderzoeksvaardigheden die centraal staan bij de competentie probleemoplossend vermogen. Hieraan gekoppeld wordt ook aandacht besteed aan de ethische aspecten rondom onderzoek doen, een natuurlijke samenhang. Als laatste zien we een sterke samenhang tussen vakspecifieke vaardigheden en beïnvloedingsvaardigheden. Dit vloeit voort uit opleidingen in met name de sector gedrag en maat- 
schappij, en in het juridische- en zorgdomein. Dit zijn opleidingen die gericht zijn op het meekrijgen van cliënten in bepaalde processen. Hiervoor is niet alleen gedegen achtergrondkennis nodig, maar is het ook zaak deze kennis op overtuigende wijze over te brengen op cliënten.

\section{Figuur 4.7}

Scores per competentiecluster voor masteropleidingen.
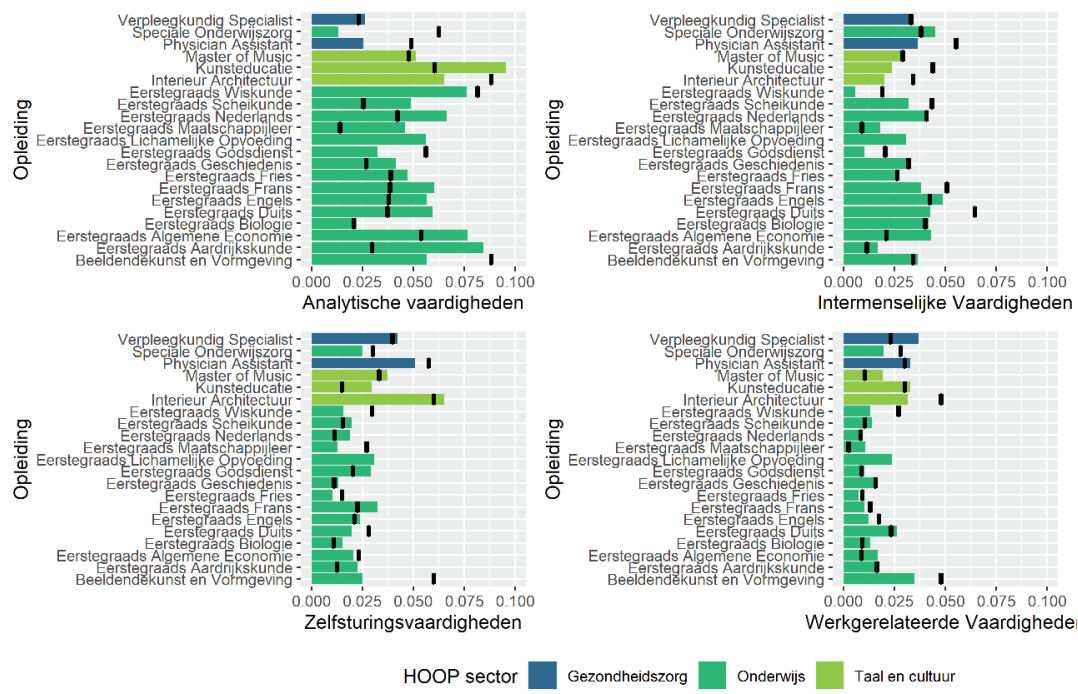

Noot. Zwarte balkjes geven score van corresponderende bacheloropleiding(en) weer. 


\section{Figuur 4.8}

\section{Correlatietabel tussen verschillende subvaardigheden}

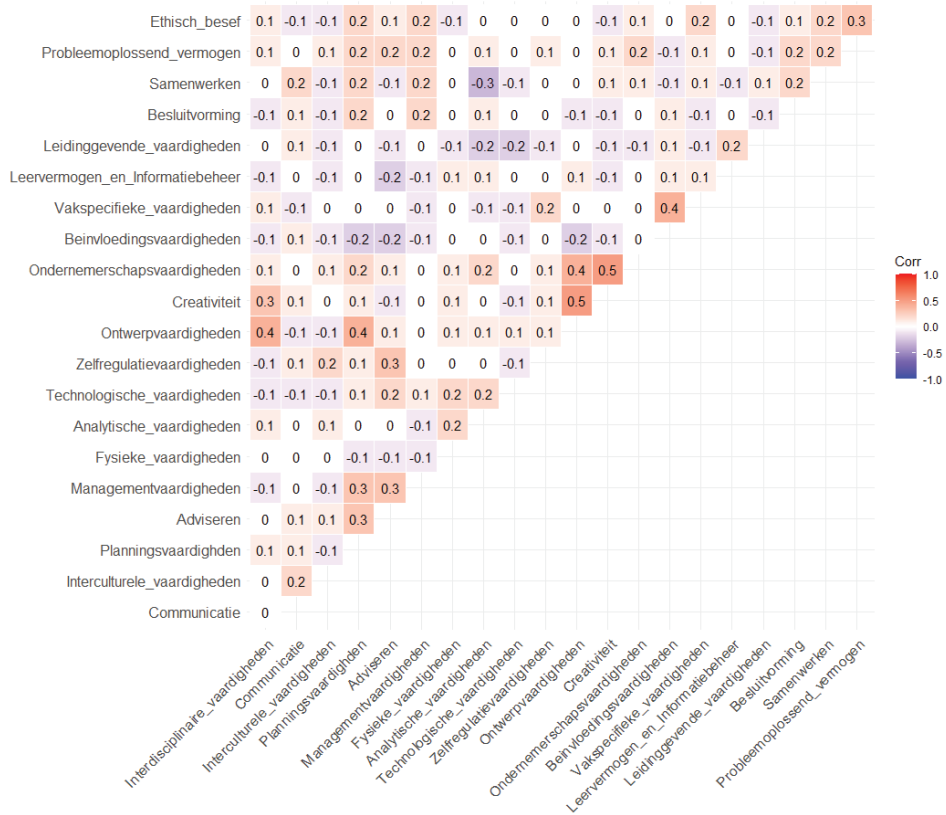




\section{Resultaten van vergelijkingen tussen vaardigheden die aan bod komen in opleidingen en de daadwerkelijke niet-routinematige vaardigheden van afgestudeerden}

\subsection{Inleiding}

In dit hoofdstuk gaan we na in hoeverre afgestudeerden van hbo-opleidingen die meer nadruk in hun leerdoelen (zoals verwoord in hun profielen) leggen op specifieke nietroutinematige vaardigheden in meerdere mate over overeenkomstige vaardigheden beschikken dan afgestudeerden van opleiding die deze vaardigheden minder benadrukken. Daarnaast gaan we na in hoeverre de vaardigheden die vooraf door hboopleidingen worden benadrukt ook de vaardigheden zijn die door het werkveld worden vereist. We gebruiken hiervoor data van de HBO-Monitor, een jaarlijks afgestudeerdenonderzoek waarin afgestudeerden van het hbo anderhalf jaar na afstuderen over hun transitie naar de arbeidsmarkt worden bevraagd. Meer dan 90\% van alle Nederlandse hogescholen neemt aan dit onderzoek deel. Zie voor meer detail: www.hbomonitor.nl.

Een deel van de HBO-Monitor vragenlijst bestaat uit een set vragen naar (1) de mate waarin afgestudeerden over niet-routinematige vaardigheden beschikken en (2) de mate waarin deze niet-routinematige vaardigheden door hun werkgevers worden vereist. Belangrijke niet-routinematige vaardigheden als creativiteit, probleemoplossend vermogen en sociale vaardigheden komen hierbij aan bod. Voor alle bacheloropleidingen die aan de HBO-Monitor meedoen zoeken we naar de vaardigheden die conceptueel het dichtst in de buurt komen bij de subclusters in het organisatiemodel (zie hoofdstuk 2). We correleren (a) per studierichting, het door afgestudeerden gerapporteerde eigen niveau van niet-routinematige vaardigheden met de mate waarin deze vaardigheden aan bod kwamen in de text-mining analyses van de opleidingsprofielen (zie hoofdstuk 3 en 4) en (b) per studierichting, het door werkgevers vereiste niveau van niet-routinematige vaardigheden met de mate waarin deze vaardigheden aan bod kwamen in de opleidingsprofielen. We voeren tevens een soortgelijke reeks analyses uit op de masteropleidingen in onze data. Vanwege het veel kleiner aantal masteropleidingen zijn deze analyses echter minder uitgebreid dan de analyses van de bacheloropleidingen. De resultaten van alle analyses worden gepresenteerd in overzichtelijke tabellen en figuren.

De vergelijking met het zelfgerapporteerde eigen competentieniveau van recent afgestudeerden kan een indicatie geven van de mate waarin de vaardigheden die in de 
opleidingsprofielen worden benadrukt tot uitdrukking komen in een hoger competentieniveau in overeenkomstige vaardigheden kort na het verlaten van de opleiding. De vergelijking met het competentieniveau dat volgens afgestudeerden in de huidige functie wordt vereist biedt zicht op de mate waarin werkgevers deze vaardigheden ook waarderen. Deze laatste vergelijking beperkt zich tot afgestudeerden die binnen hun eigen kerndomein werkzaam zijn, dat wil zeggen, in een functie werken waarvoor door de werkgever minimaal een hbo-opleiding binnen dezelfde of een verwante richting als de functie werd vereist. Om deze analyses zo min mogelijk te laten verstoren door meetfouten is gebruik gemaakt van multi-level statistische analyses om robuuste gemiddelden per hbo-opleiding van het eigen en vereiste niveau van de HBO-Monitor maten te schatten. Bij het schatten van deze gemiddelden is rekening gehouden met toevallige variaties in de meting als gevolg van een relatief klein aantal observaties en/of een relatief grote spreiding in de individuele vaardigheidsscores binnen een opleiding. In die gevallen wordt het gemiddelde gecorrigeerd in de richting van het algemene gemiddelde in het databestand.

Bij de meeste vaardigheden zijn de scores gebaseerd op heel recente data van de HBO-Monitor, namelijk van de meetjaren 2014 t/m 2017 en 2019. Om de vergelijkingsmogelijkheden te verruimen is voor een aantal subclusters gebruik gemaakt van data uit eerdere meetjaren, namelijk $2008 \mathrm{t} / \mathrm{m}$ 2012. Door veranderingen in de vragenlijsten zijn deze vaardigheden nu niet meer gevraagd. Omdat de competentieprofielen van opleidingen over de tijd kan zijn veranderd, dienen de resultaten met betrekking tot deze vaardigheden extra voorzichtig te worden geïnterpreteerd.

\subsection{Match tussen HBO-Monitor vaardigheden en text-mining subclusters}

De maten die in de HBO-Monitor zijn gehanteerd zijn conceptueel niet identiek aan de text-mining subclusters van niet-routinematige vaardigheden die wij op basis van het organisatiemodel hebben geïdentificeerd in hoofdstuk 2 en gebruikt hebben voor de text-mining analyse die wij in hoofdstukken 3 en 4 rapporteren. Om de uitkomsten van beide onderzoeken te kunnen vergelijken moeten we eerst vaststellen welke matches mogelijk en zinvol zijn. Tabel 5.1 geeft een overzicht van de vaardigheden uit de HBO-Monitor die mogelijkerwijze kunnen worden gerelateerd aan de subclusters. Bij alle vaardigheden is tevens de correlatie vermeld, op het geaggregeerde niveau van opleidingen, tussen de score op het subcluster en het gemiddelde eigen en vereiste competentieniveau van afgestudeerden volgens de HBO-Monitor. Bij een aantal subclusters is er sprake van meer dan één HBO-Monitor competentiedimensies die daaraan zouden kunnen worden gerelateerd. De vaardigheden die zwart gedrukt staan zijn de vaardigheden die in de verdere analyses in dit hoofdstuk worden gebruikt. Bij een aantal subclusters is de corresponderende HBO-Monitor dimensie snel gevonden. Analytische vaardigheden correspondeert met "vermogen om analytisch te denken", samenwerken met "vermogen om productief samen te werken", en zelfregulatievaardig- 
heden met "vermogen om zelfstandig de werkzaamheden uit te voeren". Bij een aantal andere vaardigheden is ondanks het feit dat de gebruikte terminologie iets anders is, een conceptuele link vrij gemakkelijk te leggen. Zo lijkt probleemoplossend vermogen een sterke correspondentie te tonen met "kennis van methoden en technieken van praktijkgericht onderzoek", creativiteit met "vermogen om nieuwe ideeën en oplossingen te bedenken", communicatie met "vermogen om aan anderen duidelijk te maken wat u bedoelt", leidinggevende vaardigheden met "vermogen om capaciteiten van anderen aan te spreken", interculturele vaardigheden met "vermogen om in buitenlandse talen te communiceren", planningsvaardigheden met "vermogen om conform budget, planning of richtlijnen te werken", interdisciplinaire vaardigheden met "kennis van andere vakgebieden" en technologische vaardigheden met "vermogen om informatie- \& communicatietechnologie te gebruiken". Ondanks deze sterke conceptuele correspondentie kan bij een aantal van deze vaardigheden misschien worden getwijfeld of ze de betreffende subcluster conceptueel helemaal afdekken. Er is daarom voorzichtigheid geboden bij de interpretatie van de uitkomsten.

Verder zijn er subclusters waarbij de conceptuele link meer impliciet is, of uitgesmeerd is over meerdere competentiedimensies van de HBO-Monitor. Zo kan bij leervermogen en informatiebeheer met zowel "vermogen om nieuwe dingen te leren" als "vermogen om informatie te vergaren", bij beïnvloedingsvaardigheden met "bereidheid om op te komen voor uw eigen standpunt", bij besluitvorming met "vermogen om knopen door te hakken", "vermogen om verbanden te leggen tussen verschillende zaken" en "vermogen om hoofd- van bijzaken te onderscheiden", bij ondernemerschapsvaardigheden met zowel "bereidheid om uw nek uit te steken" als met "vermogen om problemen en kansen te signaleren", en bij ethisch besef met "bereidheid om begrip te tonen voor andere standpunten". Tevens zijn er bij twee subclusters waarvoor er direct een zeer goede match werd gevonden ook andere HBO-Monitor vaardigheden die daar conceptueel aan te relateren lijkt. Zo kunnen analytische vaardigheden behalve aan "vermogen om analytisch te denken" ook worden gelinkt aan "vermogen om logisch te redeneren" en "bereidheid om ideeën van uzelf en anderen ter discussie te stellen", en kunnen zelfregulatievaardigheden behalve aan "vermogen om zelfstandig de werkzaamheden uit te voeren" ook worden gelinkt aan "vermogen om onder druk goed te functioneren". Tenslotte zijn voor drie subclusters überhaupt geen HBO-Monitor tegenhangers gevonden: adviseren, managementvaardigheden en fysieke vaardigheden. Deze subcluster spelen verder geen rol in dit hoofdstuk.

Uit tabel 5.1 blijkt verder dat de correlaties tussen de subclusters en de potentiele HBO-Monitor tegenhangers meestal niet sterk zijn en soms geheel afwezig of zelfs negatief zijn. De sterkste positieve correlaties met zowel het eigen als het vereist niveau worden gevonden bij interculturele vaardigheden, technologische vaardigheden, creativiteit en in iets mindere mate bij beïnvloedingsvaardigheden, leidinggevende vaardigheden en probleemoplossend vermogen. Interessant genoeg zijn dit bijna allemaal vaardigheden waarbij een sterk en vrij directe conceptuele link wordt verondersteld, maar waarbij een andere formulering is gebruikt. De enige uitzondering wordt gevormd door 
beïnvloedingsvaardigheden, waarbij de conceptuele link hooguit impliciet aanwezig is. Geen enkele van de vaardigheden waarbij de link direct en nagenoeg letterlijk gelijk is toont een sterke correlatie met de HBO-Monitor maten voor zowel het eigen als het vereist niveau. Bij analytische vaardigheden is er wel een relatief sterke relatie met het eigen competentieniveau van afgestudeerden, maar niet met het niveau dat in het werk werd vereist. Dit suggereert dat opleidingen die in hun competentieprofiel veel nadruk op deze vaardigheid leggen, relatief vaak ook opleidingen zijn waar de afgestudeerden zelf vinden dat ze hier sterk in zijn. Bij planningsvaardigheden en in mindere mate vakspecifieke vaardigheden, leidinggevende vaardigheden, samenwerken en communicatie zien we een tegenovergestelde situatie, namelijk een sterke relatie met het vereist niveau maar niet met het eigen niveau. Bij deze vaardigheden lijken de profielen relatief vaak een weerspiegeling te zijn van wat er in het werkveld wordt vereist. Bij de overige subclusters is geen sprake van een relatie.

Zoals gezegd is geen enkele relatie heel erg sterk, en vaak is de relatie zwak of zelfs negatief. De implicatie is dat behoorlijk wat opleidingen relatief sterk of zwak scoren op de betreffende clusters in hun competentieprofiel, zonder dat dit tot uitdrukking komt in de HBO-Monitor scores op de overeenkomstige vaardigheden. Dit hoeft uiteraard niet te betekenen dat de scores op de subclusters zoals ze naar voren komen uit de tekstanalyse van de profielen niets zeggen. De HBO-Monitor is immers opgezet vanuit een heel eigen logica, en er zijn verschillende redenen te bedenken waarom de scores uit de HBO-Monitor kunnen afwijken van die van text-mining. Ten eerste, hoewel de instrumenten die in de HBO-Monitor worden gebruikt grotendeels gebaseerd zijn op een vergelijkbaar organisatiemodel als wij voor de text-mining analyses hebben gebruikt, zijn de maten conceptueel niet identiek. Ten tweede kunnen vaardigheden ook buiten de opleiding worden opgedaan, bijvoorbeeld in het privéleven, op het werk of door natuurlijke aanleg. Ten derde gaat het om zelfinschattingen van afgestudeerden, die wellicht gevoelig kunnen zijn voor mispercepties en/of misrepresentatie door afgestudeerden. ${ }^{5}$ Tenslotte worden niet-routinematige vaardigheden in de HBO-Monitor doorgaans gemeten aan de hand van een surveyvraag (of een beperkt aantal vragen) terwijl de tekstanalyse gebruikt maakt van een rijk corpus van zoekwoorden. Desondanks is het nuttig om in de rest van dit hoofdstuk iets dieper te duiken in de correlaties tussen de vergelijkbare vaardigheidsclusters uit beide bronnen, zodat we meer zicht krijgen op hoe deze uitkomsten het beste kunnen worden geïnterpreteerd.

5 Uit onderzoek is gebleken dat dergelijke zelfinschattingen op geaggregeerd niveau tamelijk robuust zijn (zie Allen en Belfi, 2018), maar door het subjectief aspect zijn onbedoelde vertekeningen niet geheel uit te sluiten. 


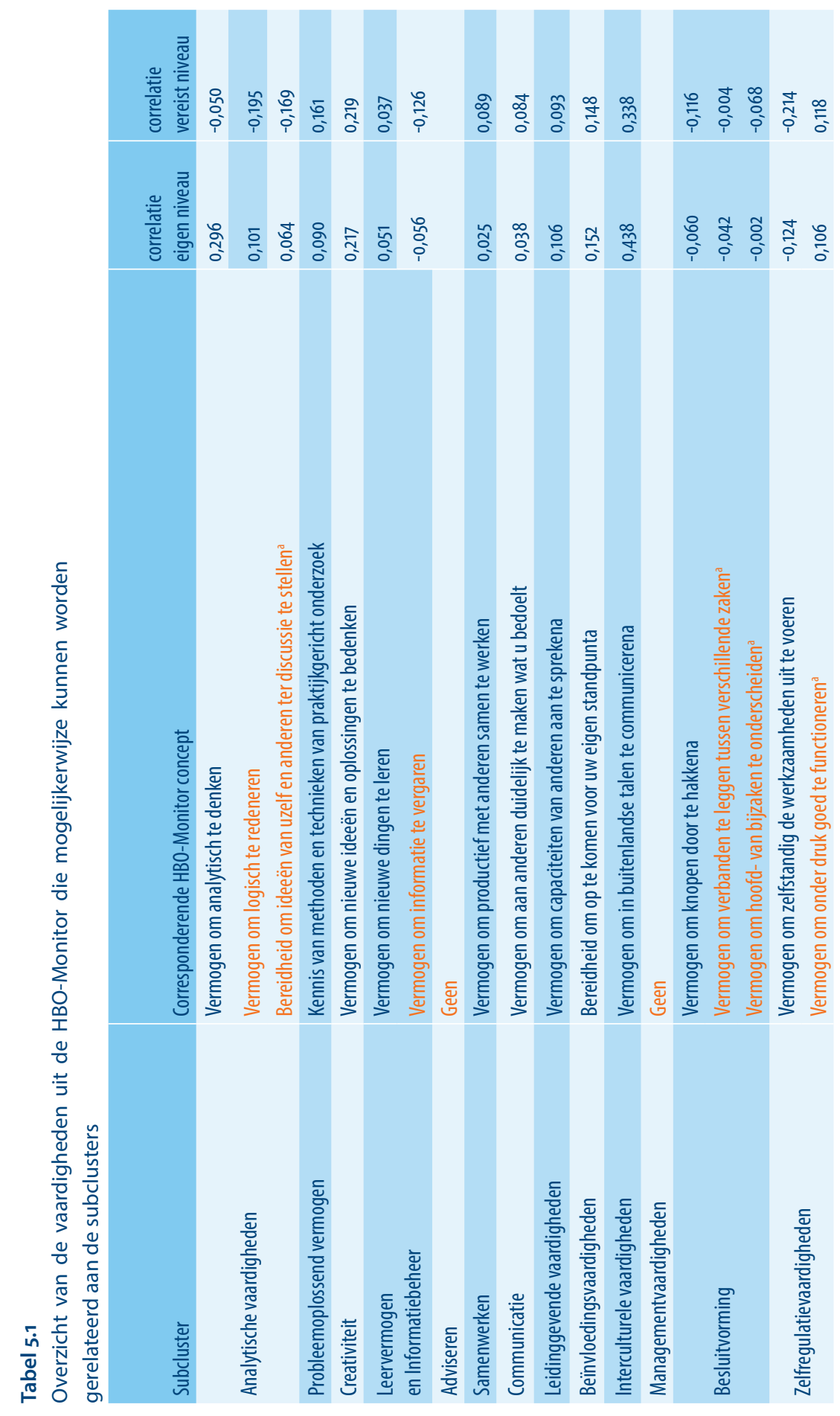


홍 目管言

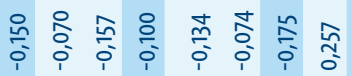
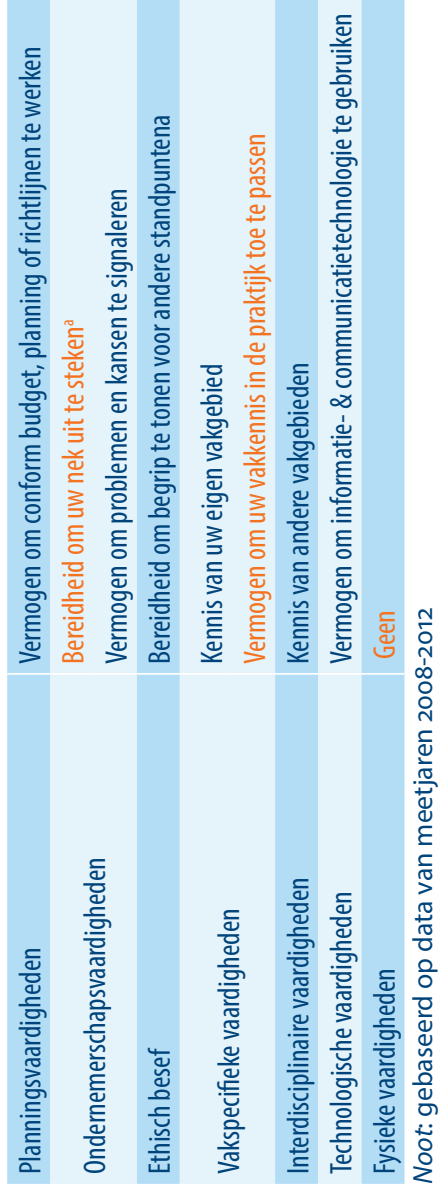


\subsection{Rangordening van vaardigheden in text-mining analyses en corresponderende HBO-Monitor competentiematen}

Eén van de eerste punten waarop een verschil kan ontstaan tussen de text-mining subclusters en de corresponderende HBO-Monitor vaardigheden is hun relatief gewicht ten opzichte van elkaar. Vaardigheden die veel worden genoemd in de opleidingsprofielen hoeven niet altijd ook de vaardigheden te zijn waarop afgestudeerden zelf hoog scoren en/of waarop werkgevers veel nadruk leggen. Wanneer dit niet of minder het geval is, legt dit beperkingen op de sterke van de correlaties. Om hier zicht te geven staat in figuur 5.1 de rangordening van de scores volgens de drie maten afgebeeld.

De rode stipjes in figuur 5.1 geven het gemiddelde score aan over alle opleidingen, en de zwarte stipjes de scores van afzonderlijke opleidingen. Uit de figuur komt naar voren dat de competentiematen uit de HBO-Monitor een behoorlijk andere rangordening tonen dan de text-mining subclusters waaraan ze worden gerelateerd. Waar analytische vaardigheden uit de text-mining naar voren komt als de belangrijkste dimensie, is dit bij beide HBO-Monitor-maten een middenmoter. Het omgekeerde geldt bij zelfregulatievaardigheden: hbo-afgestudeerden schatten hun eigen niveau van deze competentie erg hoog in, en geven ook aan dat die zeer belangrijk is in hun werk. Ondanks dergelijke verschillen zijn er ook correspondenties tussen de subclusters en de HBO-Monitorequivalenten. Zo wordt communicatie met name door werkgevers sterk gewaardeerd, en worden interculturele en interdisciplinaire vaardigheden meestal laag ingeschat en ook door werkgevers weinig gewaardeerd. Opvallend daarbij is echter de grote spreiding tussen opleidingen in het eigen niveau en het vereiste niveau van interculturele vaardigheden (in de HBO-Monitor vertegenwoordigd door buitenlandse taalvaardigheden). Deze spreiding zien we niet terug bij deze subcluster in de text-mining scores.

Figuur 5.1

Gemiddelde vaardigheidsscores van text-mining analyse en HBO-Monitor over alle opleidingen.

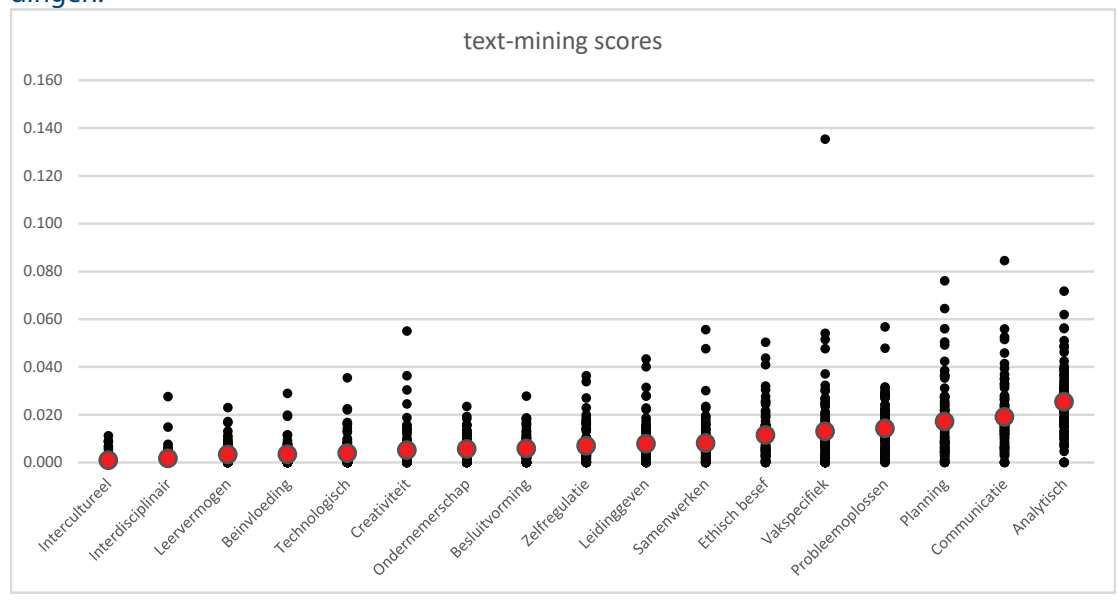




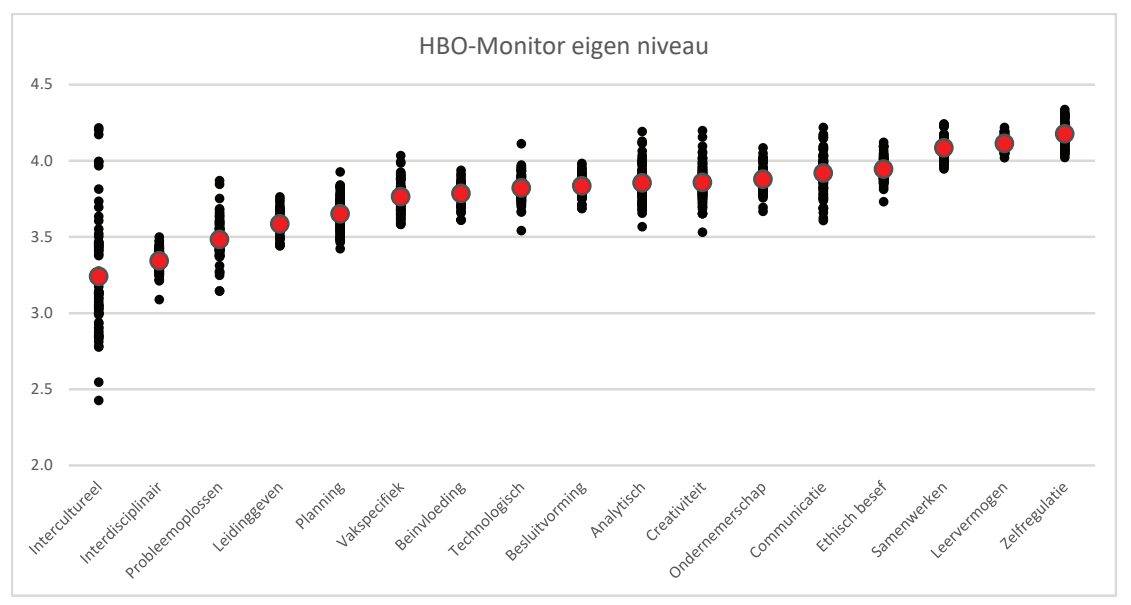

HBO-Monitor vereist niveau

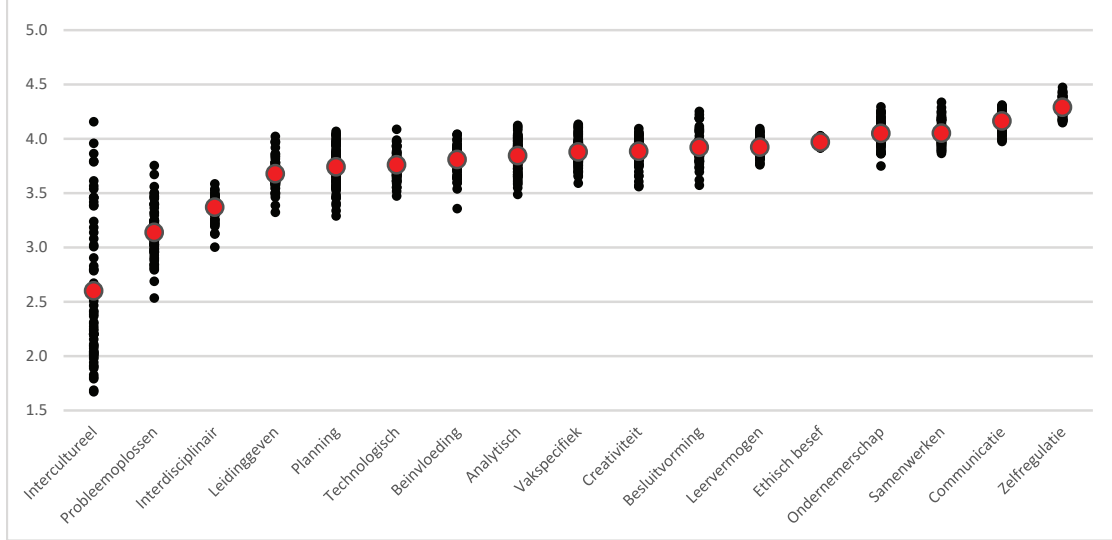

\section{4 "Goede" en "minder goede" matches tussen verschillende operationalisaties}

In deze paragraaf kijken we in meer detail naar de relaties, door opleidingen te identificeren waar de verwachte correspondentie wel aanwezig is, en meer in het bijzonder naar opleidingen waar de correspondentie zwak of geheel afwezig is. Op zo'n manier kunnen we zien of er een bepaalde subset aan opleidingen is die de sterkte van de relaties in het algemeen naar beneden haalt. We doen dit door de maten eerst te standaardiseren, en vervolgens opleidingen te identificeren die bovengemiddeld scoren op text-mining maar ondergemiddeld op de HBO-Monitor maten, of andersom. Om te voorkomen dat opleidingen die net onder of boven de lijn vallen ten onrechte als "mismatch" worden gezien, hanteren we als additionele restrictie dat het verschil tussen de gestandaardiseerde scores minstens 1,5 moet bedragen. Dit betekent dat de HBO-Monitor maten per 
saldo minimaal 1,5 standaardafwijkingen verwijderd moeten zijn van de text-mining maten.

Ter illustratie staat in Figuur 5.2 de gestandaardiseerde scores voor de subcluster analytische vaardigheden. De horizontale as geeft de positie aan ten opzichte van het gemiddelde op de text-mining scores, de verticale as de positie in termen van de HBO-Monitor maten. De bovenste grafiek toont de relatie met het eigen competentieniveau, de onderste grafiek de relatie met het vereiste niveau. De groene stipjes geven opleidingen aan waar de match min of meer zoals verwacht is, de blauwe stipjes de opleidingen waar de match duidelijk afwezig is. Bij deze opleiding staan ook de opleidingsnamen afgebeeld.

\section{Figuur 5.2}

De gestandaardiseerde scores voor de subcluster analytische vaardigheden

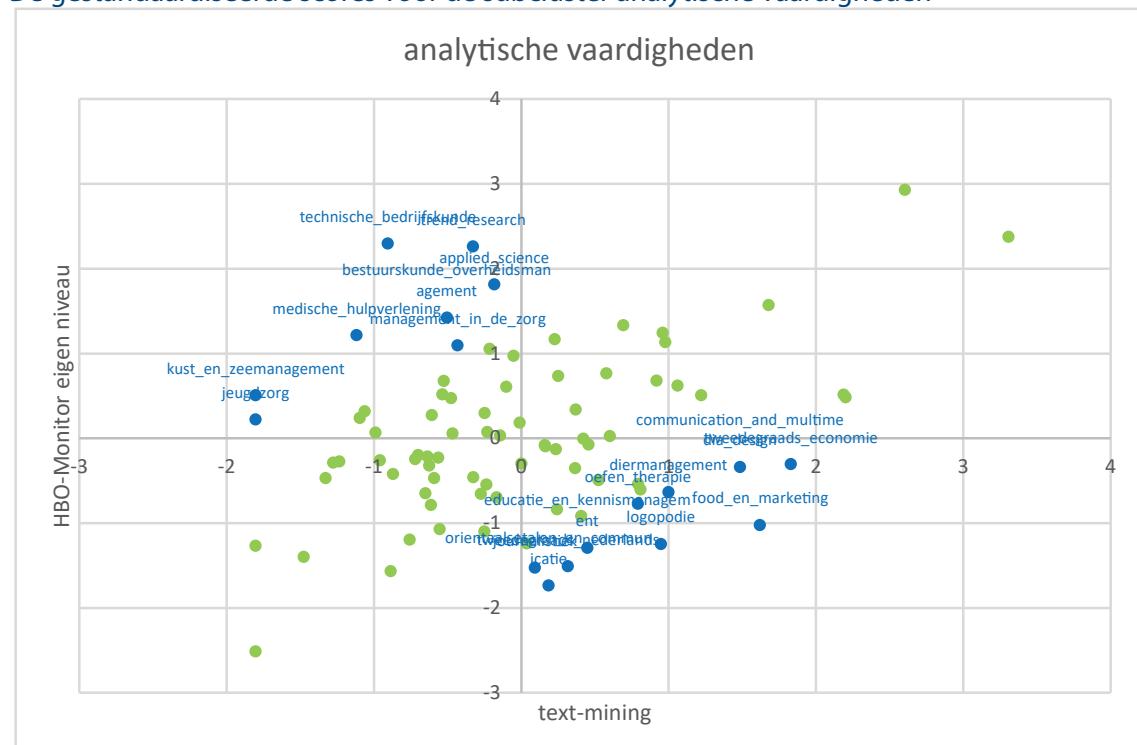




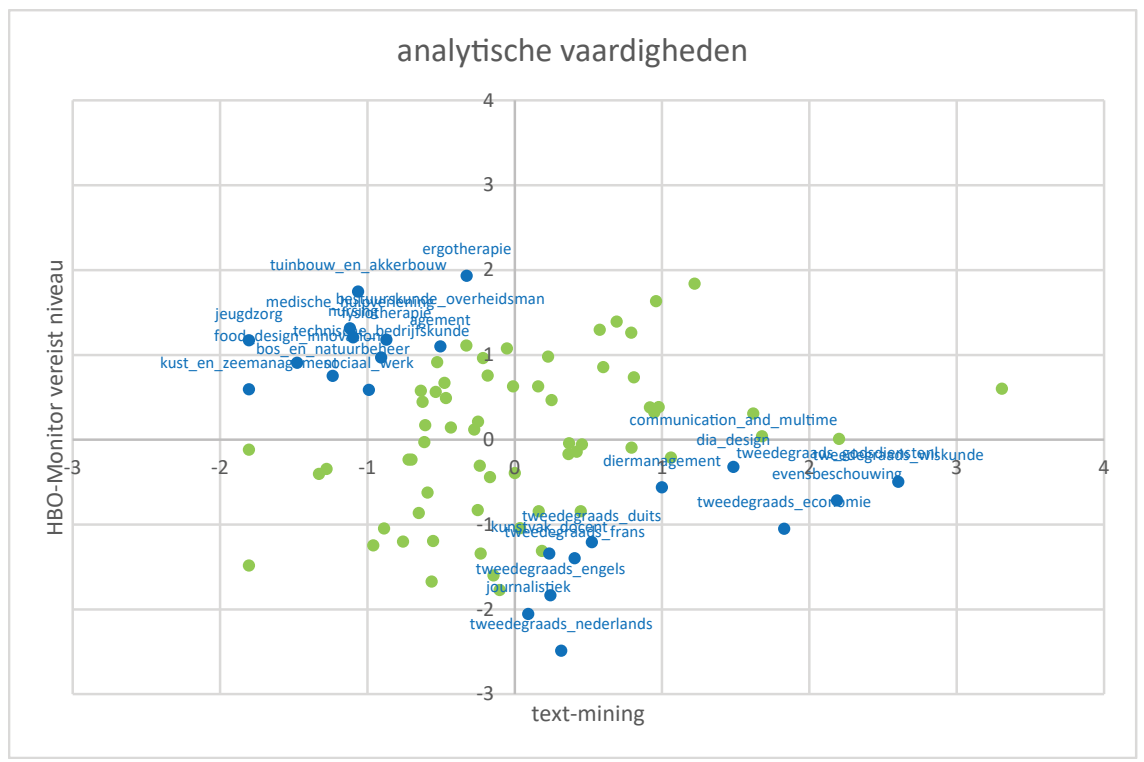

In Figuur 5.2 wordt duidelijk waarom de correlatie relatief sterk is voor dit subcluster in termen van het eigen competentieniveau, maar niet voor het vereiste niveau. In de grafiek boven zijn iets minder "mismatches", staan de mismatches iets dichter bij de diagonaal, en strekken de "goede matches" consistent verder uit in de goede richting, zowel naar boven als naar onder, dan in de onderste grafiek. Opvallend blijken relatief veel van de "mismatches" in termen van vereist niveau uit tweedegraads lerarenopleidingen. Bij veel van deze opleidingen komt een hoge score op analytische vaardigheden uit de text-mining naar voren, terwijl volgens de HBO-Monitor deze vaardigheid minder dan gemiddeld door werkgevers (scholen) wordt vereist. Interessant genoeg zien we dit niet terug bij het eigen niveau. Dit suggereert dat de hoge text-mining score van veel lerarenopleidingen tot uitdrukking komt in een hoog eigen niveau kort na afstuderen, maar niet in een hoog vereist niveau van werkgevers.

Het zou te veel ruimte in beslag nemen om deze relaties te laten zien voor alle subclusters, dus is het zoeken naar een iets beknopte manier om de resultaten zichtbaar te maken. Hiertoe construeren we samenvattende maten die het aantal opleidingen per vaardigheid, en het aantal vaardigheden per opleiding aangeven waar er volgens bovengenoemde maatstaven "slecht gematcht" is in termen van eigen en/of vereist niveau.

Tabel 5.2 laat per vaardigheid zien welk percentage van de opleidingen "slechte matches" zijn. Zoals op basis van de correlaties in Tabel 5.1 zou mogen worden verwacht, verschilt dit aandeel aanzienlijk per vaardigheid. Wat betreft de relatie met eigen competentieniveau, laat de tabel zien dat bij een drietal vaardigheden - communicatie, besluitvorming en ethisch besef - een kwart of meer van de opleidingen een "slechte match" toont. 
Daartegenover staat dat twee vaardigheden - beïnvloedingsvaardigheden en interculturele vaardigheden - voor minder dan een op de tien opleidingen "slecht gematcht" is. Wat betreft de relatie met het vereiste competentieniveau zien we ook drie vaardigheden die voor een kwart of meer een "slechte match" tonen: analytische vaardigheden, zelfregulatievaardigheden en ethisch besef. Er zijn echter geen vaardigheden waarbij een "slechte match" op vereist niveau bij minder dan 10\% van de opleidingen wordt gezien. Wel is er een flink aantal vaardigheden - creativiteit, leidinggevende vaardigheden, interculturele vaardigheden, planningsvaardigheden, vakspecifieke vaardigheden en interdisciplinaire vaardigheden - waarop minder dan $15 \%$ van de opleidingen "slecht gematcht" zijn in termen van vereist niveau.

\section{Tabel 5.2}

Aandeel "slecht gematchte" opleidingen per vaardigheid

\begin{tabular}{|l|c|c|}
\hline & HBO-Monitor eigen niveau & HBO-Monitor vereist niveau \\
\hline Analytische vaardigheden & $21 \%$ & $27 \%$ \\
\hline Probleemoplossend vermogen & $21 \%$ & $19 \%$ \\
\hline Creativiteit & $16 \%$ & $13 \%$ \\
\hline Leervermogen en Informatiebeheer & $20 \%$ & $16 \%$ \\
\hline Samenwerken & $16 \%$ & $17 \%$ \\
\hline Communicatie & $29 \%$ & $21 \%$ \\
\hline Leidinggevende vaardigheden & $18 \%$ & $14 \%$ \\
\hline Beïnvloedingsvaardigheden & $6 \%$ & $15 \%$ \\
\hline Interculturele vaardigheden & $7 \%$ & $13 \%$ \\
\hline Besluitvorming & $25 \%$ & $18 \%$ \\
\hline Zelfregulatievaardigheden & $22 \%$ & $26 \%$ \\
\hline Planningsvaardigheden & $24 \%$ & $12 \%$ \\
\hline Ondernemerschapsvaardigheden & $24 \%$ & $24 \%$ \\
\hline Ethisch besef & $26 \%$ & $32 \%$ \\
\hline Vakspecifieke vaardigheden & $20 \%$ & $12 \%$ \\
\hline Interdisciplinaire vaardigheden & $16 \%$ & $13 \%$ \\
\hline Technologische vaardigheden & $15 \%$ & $19 \%$ \\
\hline
\end{tabular}

Uit tabel 5.2 is gebleken dat voor de meeste vaardigheden in grote lijnen de verwachte relatie tussen text-mining en de HBO-Monitor maten naar voren komt, maar dat de relatie tussen de vaardigheden zoals gemeten in hbo-profielen en HBO-Monitor lang niet altijd eenduidig is. Het is belangrijk om te weten in hoeverre er systematiek zit in deze uitzonderingen. Zijn het steeds dezelfde opleidingen die afwijken van het verwachte patroon, of is dit min of meer random verdeeld? Tabel 5.3 toont de opleidingen die volgens dit criterium het "best gematcht" zijn in termen van eigen niveau over alle vaardigheden bekeken, en de opleidingen die volgens deze criterium het "slechtst gematcht" zijn. De getallen geven aan hoeveel "slechte matches" voor de betreffende opleidingen zijn genoteerd. 
Tabel 5.3

Overzicht van het 'beste' en het 'slechtste' gematcht zijn in termen van eigen niveau over alle vaardigheden bekeken

\begin{tabular}{|l|l|l|l|}
\hline "slechtste" matches qua eigen niveau & & "beste" matches eigen niveau & 0 \\
\hline Accountancy & 8 & Creative business & 0 \\
\hline Hotel onderwijs & 8 & Geo media design & 0 \\
\hline Tuin en landschapsinrichting & 8 & Integrale veiligheidskunde & 0 \\
\hline Oriëntaalse talen en communicatie & 7 & Ondernemerschap en retailmanagement & 0 \\
\hline Commerciële economie & 6 & Rechten & 0 \\
\hline Jeugdzorg & 6 & Toegepaste gerontologie & 0 \\
\hline Kunstvakdocent & 6 & Tuinbouw en akkerbouw & 0 \\
\hline Logopedie & 6 & Tweedegraads consumptieve techniek & \\
\hline Technische bedrijfskunde & 6 & & \\
\hline Tweedegraads maatschappijleer & 6 & & \\
\hline
\end{tabular}

De hoogste score die een opleiding kan aannemen volgens deze maatstaf is 17, namelijk het aantal subclusters waarvoor een HBO-Monitor tegenhanger werd gevonden. Geen enkele opleiding is slecht gematcht op meer dan 8 van deze dimensies, dat wil zeggen, geen opleiding heeft een slechte match op meer dan de helft van de dimensies. Het gemiddelde over alle opleidingen bedraagt iets meer dan 3 dimensies $(3,1$ om precies te zijn). De opleidingen die volgens deze maatstaf "slecht gematcht" zijn, zijn verdeeld over vrijwel alle hbo-sectoren. Er zijn 8 opleidingen die goed zijn gematcht op alle dimensies, en ook deze opleidingen zijn een mix in termen van opleidingssectoren. Tabel 5.4 toont de "goede" en "slechte" matches in termen van het vereiste niveau.

\section{Tabel 5.4}

Overzicht van het 'beste' en het 'slechtste' gematcht zijn in termen van vereist niveau over alle vaardigheden bekeken

\begin{tabular}{|l|l|l|l|}
\hline \multicolumn{1}{|c|}{ "slechtste" matches qua vereist niveau } & \multicolumn{2}{c|}{ "beste" matches qua vereist niveau } \\
\hline Ergotherapie & 10 & Geo media design & 0 \\
\hline Hotel onderwijs & 8 & ICT & 0 \\
\hline Jeugdzorg & 8 & Integrale veiligheidskunde & 0 \\
\hline Pedagogiek & 8 & Leisure event management & 0 \\
\hline Commerciële economie & 6 & Toegepaste gerontologie & 0 \\
\hline Fysiotherapie & 6 & Tweedegraads biologie & 0 \\
\hline Kunstvakdocent & 6 & Tweedegraads consumptieve techniek & 0 \\
\hline Kust- en zeemanagement & 6 & Tweedegraads geschiedenis & 0 \\
\hline logistiek & 6 & & \\
\hline Sociaal pedagogische hulpverlening & 6 & & \\
\hline Tuin en landschapsinrichting & 6 & & \\
\hline Tuinbouw en akkerbouw & 6 & & \\
\hline Tweedegraads wiskunde & 6 & & \\
\hline
\end{tabular}


Hoewel het gemiddelde aantal slechte matches iets kleiner is voor het vereist niveau $(2,9$ vs. 3,1$)$, is het aantal opleidingen met zes of meer slechte matches groter. Een aantal hiervan komen ook voor in Tabel 5.2: Hotelonderwijs, tuin en Landschapsinrichting, Commerciële Economie, Jeugdzorg en Kunstvak docent. Dit zijn opleidingen waarvan de match in het algemeen 'slecht' lijkt te zijn. De overige opleidingen passen relatief slecht in termen van eigen niveau maar minder slecht in termen van vereist niveau of andersom. Het is van belang om te zien welk effect deze 'slechte matches' hebben op de correlaties. Hiertoe worden opleidingen die zes of meer "slechte matches" tonen buiten beschouwing gelaten, en worden de correlaties op de overige opleidingen berekend. Dit staat afgebeeld in Tabel 5.5.

\section{Tabel 5.5}

Correlaties zonder'slechte matches'

\begin{tabular}{|l|r|r|r|r|}
\hline & eigen niveau & & vereist niveau \\
& alle & selectie & alle & selectie \\
\hline Analytische vaardigheden & 0,30 & 0,36 & $-0,05$ & 0,02 \\
\hline Probleemoplossend vermogen & 0,09 & 0,23 & 0,16 & 0,23 \\
\hline Creativiteit & 0,22 & 0,24 & 0,22 & 0,25 \\
\hline Leervermogen en informatiebeheer & 0,05 & 0,03 & 0,04 & 0,14 \\
\hline Samenwerken & 0,02 & 0,09 & 0,09 & 0,16 \\
\hline Communicatie & 0,04 & 0,11 & 0,08 & 0,19 \\
\hline Leidinggevende vaardigheden & 0,11 & 0,10 & 0,09 & 0,13 \\
\hline Beïnvloedingsvardigheden & 0,15 & 0,21 & 0,15 & 0,20 \\
\hline Interculturele vaardigheden & 0,44 & 0,55 & 0,34 & 0,50 \\
\hline Besluitvorming & $-0,04$ & 0,07 & 0,00 & 0,24 \\
\hline Zelfregulatievaardigheden & $-0,12$ & 0,04 & $-0,21$ & $-0,14$ \\
\hline Planningsvaardigheden & $-0,15$ & $-0,09$ & 0,41 & 0,40 \\
\hline Ondernemerschapsvaardigheden & $-0,16$ & $-0,09$ & $-0,05$ & 0,00 \\
\hline Ethisch besef & $-0,10$ & $-0,04$ & $-0,18$ & $-0,04$ \\
\hline Vakspecifieke vaardigheden & $-0,13$ & $-0,15$ & 0,12 & 0,09 \\
\hline Interdisciplinaire vaardigheden & $-0,17$ & $-0,23$ & 0,06 & 0,13 \\
\hline Technologische vaardigheden & 0,26 & 0,29 & 0,20 & 0,21 \\
\hline
\end{tabular}

Zoals zou worden verwacht worden de correlaties positiever wanneer we de "slechte" matches weglaten. Dit is per saldo min of meer per definitie het geval. Interessanter is het feit dat de verbeteringen veel sterker zijn voor sommige vaardigheden dan voor anderen. Zo zien we bij Probleemoplossend vermogen en Interculturele vaardigheden dat de relatie met eigen competentieniveau nog sterker wordt dan het daarvoor was. Bij Leervermogen en Informatiebeheer, Communicatie, Interculturele vaardigheden en Besluitvorming wordt het verband met het vereist niveau versterkt. Alleen in het geval van Interculturele vaardigheden was het verband daarvoor redelijk sterk. Bij de andere 
vaardigheden is nu een betekenisvol verband met het vereiste niveau waar ervoor hooguit een zeer zwak verband te zien was.

Ondanks deze verbeteringen is over de hele linie nog altijd geen heel sterk verband te zien tussen de text-mining scores en de HBO-Monitor maten, en in een aantal gevallen zijn de correlaties nog altijd afwezig of zelfs negatief. Het is moeilijk om bij voorbaat te bepalen welke conclusies hieruit dienen te worden getrokken. De competentieprofielen van de opleidingen geven eerst en vooral aan waar verschillende opleidingen zich op willen richten in termen van vaardigheden. Dat dit niet heel sterk tot uitdrukking komt in het eigen niveau van afgestudeerden en/of het niveau dat in het werkveld is vereist, hoeft niet zonder meer te betekenen dat opleidingen daarin niet zijn geslaagd. We weten immers niet wat het beginniveau was van instromende studenten. Vooral gezien het feit dat veel van deze vaardigheden ook buiten het onderwijs te ontwikkelen zijn, is dit geen onbelangrijke kanttekening. Het is verder niet onwaarschijnlijk dat afgestudeerden zich bij het beoordelen van de vereisten van het werkveld, zich veel laten leiden door de vaardigheden waarover ze zelf vooral beschikken.

\subsection{De relatie tussen text-mining en HBO-Monitor maten bij masteropleidingen}

Zoals aan het begin van dit hoofdstuk is opgemerkt, is vanwege de veel kleinere aantallen en de beperking in termen van opleidingssector, veel minder te zeggen over de relatie tussen text-mining en de $\mathrm{HBO}-$ Monitor maten bij masteropleidingen dan bij bacheloropleidingen. Toch is het zinvol om kort hierbij stil te staan. In tabel 5.6 staan de correlaties tussen de maten bij masteropleidingen.

Zoals op basis van de kleine aantallen zou worden verwacht, lopen de correlaties sterk uiteen. Bij het eigen niveau zien we voor Leervermogen en Informatiebeheer, Leidinggevende vaardigheden, Interculturele vaardigheden en Samenwerken behoorlijk sterke correlaties in de verwachte richting, en bij Technologische vaardigheden, Ethisch besef, Beïnvloedingsvaardigheden, Analytische vaardigheden en Communicatie zwakker maar nog altijd duidelijk positieve correlaties. Daartegenover staan tamelijk sterke negatieve relaties voor Planningsvaardigheden, Probleemoplossend vermogen, Besluitvorming en Zelfregulatievaardigheden. Het patroon is nog meer gemengd voor de relatie met het vereist niveau, waar we zien dat alleen Leidinggevende vaardigheden, Interculturele vaardigheden en in mindere mate Ethisch besef, Samenwerken en Leervermogen en Informatiebeheer een duidelijk positieve relatie tonen, en Besluitvorming en Zelfregulatievaardigheden een duidelijk negatieve relatie. 


\section{Tabel 5.6}

Correlaties tussen text-mining en HBO-Monitor maten bij masteropleidingen

\begin{tabular}{|l|r|r|}
\hline & HBO-Monitor eigen niveau & HBO-Monitor vereist niveau \\
\hline Analytische vaardigheden & 0,137 & $-0,141$ \\
\hline Probleemoplossend vermogen & $-0,279$ & 0,085 \\
\hline Creativiteit & $-0,017$ & $-0,034$ \\
\hline Leervermogen en Informatiebeheer & 0,610 & 0,209 \\
\hline Samenwerken & 0,437 & 0,229 \\
\hline Communicatie & 0,125 & $-0,097$ \\
\hline Leidinggevende vaardigheden & 0,516 & 0,745 \\
\hline Beïnloedingsvaardigheden & 0,160 & 0,014 \\
\hline Interculturele vaardigheden & 0,443 & 0,480 \\
\hline Besluitvorming & $-0,382$ & $-0,376$ \\
\hline Zelfregulatievaardigheden & $-0,477$ & $-0,479$ \\
\hline Planningsvardigheden & $-0,219$ & $-0,099$ \\
\hline Ondernemerschapsvaardigheden & 0,097 & $-0,063$ \\
\hline Ethisch besef & 0,244 & 0,244 \\
\hline Vakspecifieke vaardigheden & $-0,198$ & 0,017 \\
\hline Interdisciplinaire vaardigheden & $-0,006$ & $-0,085$ \\
\hline Technologische vaardigheden & 0,267 & $-0,024$ \\
\hline
\end{tabular}

Tabel 5.7 vergelijkt alle maten tussen bachelors en masters. Door deze vergelijking kunnen we zien of vaardigheden die volgende text-mining hoger of lager scoren voor masters dan voor bachelors, dit ook doen voor de HBO-Monitor scores. Volgens text-mining worden Analytische vaardigheden, Leervermogen en Informatiebeheer, Beïnvloedingsvaardigheden, Communicatie en Besluitvorming gemiddeld beduidend meer benadrukt voor masteropleidingen dan voor bacheloropleidingen. We zien veel minder grote relatieve verschillen bij de HBO-Monitor, maar voor al deze vaardigheden zien we ook een hoger gemiddelde eigen niveau bij masteropleidingen dan bij bacheloropleidingen. Dit lijkt echter te liggen aan het feit dat vrijwel alle vaardigheden hoger worden ingeschat door bachelors dan door masters. Bij het vereist niveau is het meestal het tegenovergesteld het geval: masters schatten het vereist niveau op de meeste vaardigheden lager in dan bachelors. Dit kan liggen aan het fenomeen waarop boven is gezinspeeld, namelijk dat afgestudeerden het vereist niveau inschatten in relatie tot hun eigen niveau. Wanneer men het eigen niveau hoger inschat, zou mogelijk andere normen kunnen worden gehanteerd bij het vereist niveau. Uit tabel 5.6 wordt tevens duidelijk dat volgens de text-mining veel vaardigheden gemiddeld beduidend lager scoren bij masteropleidingen dan bij bacheloropleidingen. Dit is vooral het geval bij Planningsvaardigheden, Technologische vaardigheden, Creativiteit en Ondernemerschapsvaardigheden. Op Technologische vaardigheden na zijn dit vaardigheden waarop afgestudeerde masters zichzelf hoger inschatten dan afgestudeerde bachelors. Wellicht zijn dit vaardigheden die voor masters veelal als vanzelfsprekend worden geacht, waardoor het niet nodig wordt gevonden om ze in de competentieprofielen sterk te benadrukken. 


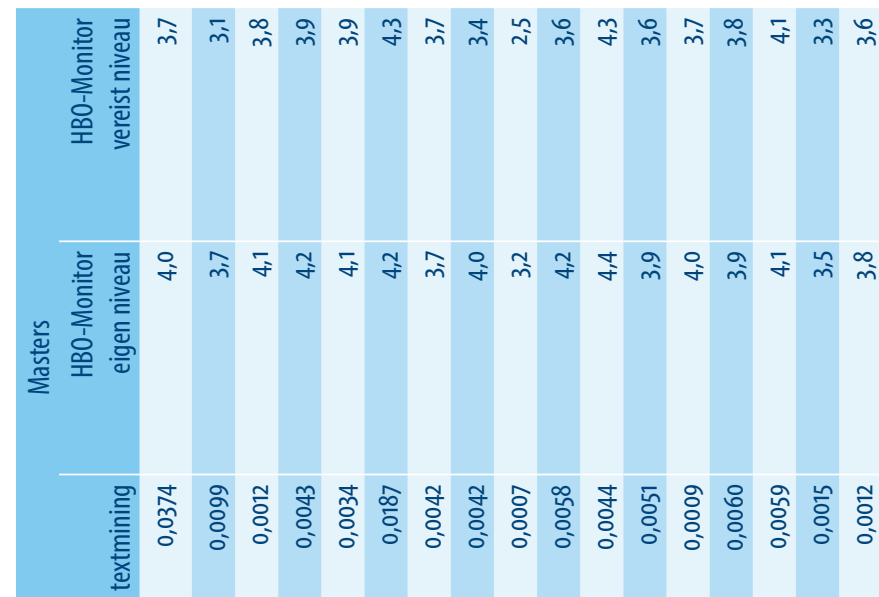

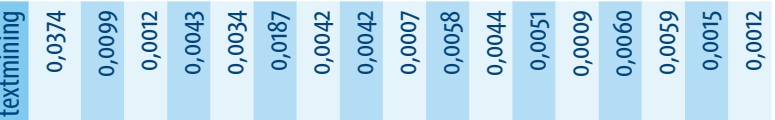

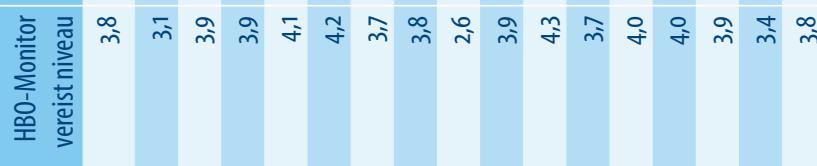

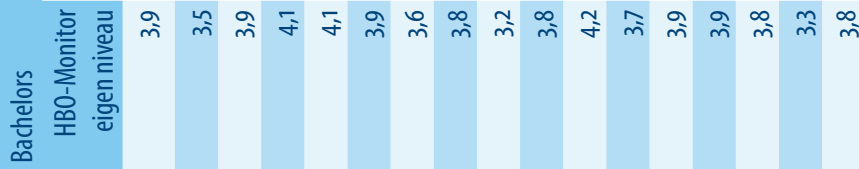

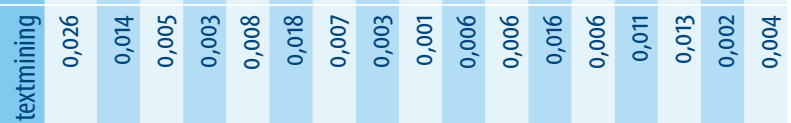

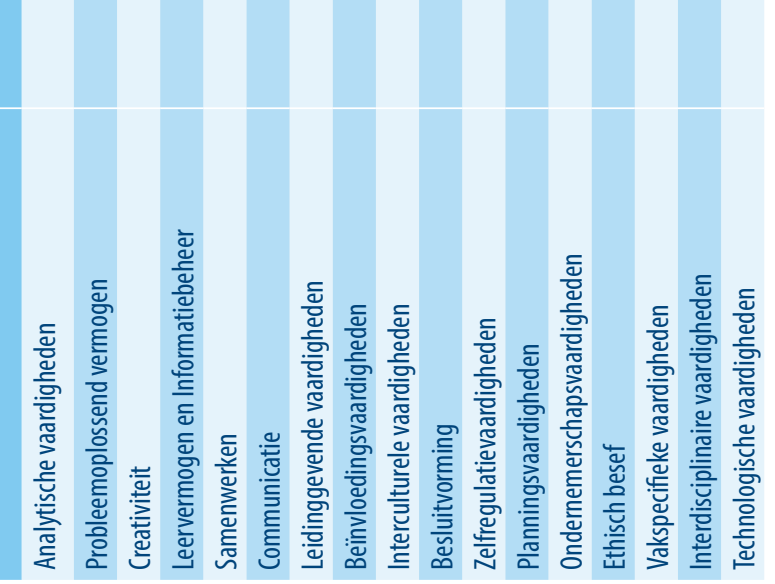




\section{Conclusie en discussie}

Het in dit rapport beschreven onderzoek had als hoofddoel om meer zicht te krijgen op de mate waarin in het huidige hoger beroepsonderwijs (hbo) aandacht wordt besteed aan het bijbrengen van niet-routinematige vaardigheden. Om dit te onderzoeken hebben we tekstanalyses (text-mining) technieken gebruikt om te bepalen welke van deze vaardigheden veel worden benadrukt in de beschreven competentieprofielen van hbo-opleidingen. Om na te gaan of afgestudeerden aan het einde van hun hboopleiding daadwerkelijk over deze vaardigheden beschikken hebben we de resultaten van deze analyses vergeleken met zelfgerapporteerde vaardigheden van hbo-afgestudeerden uit de jaarlijkse HBO-Monitor.

\subsection{Organisatiemodel}

Voordat we deze analyses konden verrichten moest eerst worden vastgesteld hoe nietroutinematige vaardigheden dienen te worden gedefinieerd. In hoofdstuk 2 is hiertoe een organisatiemodel opgesteld dat grotendeels is gebaseerd op het bestaande model van Autor en collega's (2003). Zij definiëren niet-routinematige vaardigheden, als vaardigheden die niet gemakkelijk door computers kunnen worden vervangen, en die complementair zijn aan geautomatiseerde activiteiten, waardoor de vraag ernaar als gevolg van automatisering juist toegenomen is. Dit in contrast tot routinematige vaardigheden, die in toenemende mate vervangen worden door geautomatiseerde processen. Zij delen deze vaardigheden nader in abstracte vaardigheden en handvaardigheden. Wij werkten hun beschrijving van abstracte vaardigheden nader uit en kwamen tot drie hoofdclusters:

I. Analytische en probleemoplossende vaardigheden, nader onderverdeeld in de subclusters analytische vaardigheden, probleemoplossende vaardigheden, creativiteit, leervermogen en informatiebeheer, en adviserende vaardigheden;

II. Interpersoonlijke vaardigheden, nader onderverdeeld in de subclusters samenwerken, communicatie, leidinggevende vaardigheden, beïnvloedingsvaardigheden en interculturele vaardigheden

III. Zelfsturingsvaardigheden, waaronder zelfregulatievaardigheden, managementvaardigheden, besluitvorming, planningsvaardigheden, ondernemerschapsvaardigheden en ethisch besef.

Hieraan voegen we bovendien nog een vierde cluster toe, namelijk werkgerelateerde vaardigheden. Hieronder vallen vakspecifieke vaardigheden, interdisciplinaire vaardigheden, technologische (ICT) vaardigheden, fysieke vaardigheden en ontwerpvaardigheden. Strikt genomen vallen hiervan enkel de fysieke vaardigheden onder het overkoe- 
pelende begrip van niet-routinematige vaardigheden, maar omdat al deze vakspecifieke vaardigheden in veel van de competentieprofielen van opleidingen worden genoemd, en ook zeker belangrijk kunnen zijn in een sterk geautomatiseerde economie, zijn deze vaardigheden in onze analyses meegenomen. Dit organisatiemodel is leidend geweest bij de empirische kwantificering van de mate waarin deze vaardigheden verwoord zijn in profielen van hbo-opleidingen.

\subsection{Belangrijkste resultaten}

Wat de tekstanalyses (text-mining) betreft, kunnen we kort samenvattend stellen dat alle door ons gedefinieerde clusters van niet-routinematige vaardigheden terug zijn gevonden binnen de door ons onderzochte hbo-profielen. Er zijn daarnaast weinig of geen termen gebruikt in de profielbeschrijvingen die niet onder te brengen waren bij een van de genoemde subclusters. Hiermee wordt bevestigd dat het gehanteerde organisatiemodel goed aansluit bij de kaders die door profielexperts bij de verschillende opleidingen zijn gebruikt. We kunnen in het algemeen ook stellen dat er voldoende aandacht is voor deze vaardigheden in het hbo als geheel.

We zien echter wel variëteit in de aanwezigheid van niet-routinematige vaardigheden, zowel tussen verschillende onderwijssectoren, als tussen opleidingen binnen een specifieke onderwijssector. Dit geeft aan dat de mate waarin verschillende vaardigheden aangeleerd worden sterk kan verschillen van opleiding tot opleiding, iets wat onder meer te verklaren valt door opleidingsspecifieke kenmerken. Verder verschilt het per cluster welke vaardigheden voorkomen in profielen. Binnen sommige clusters komen alle vaardigheden in ruime mate aan bod, terwijl voor andere clusters slechts enkele vaardigheden ruim aan bod komen. De belangrijkste bevindingen kunnen we als volgt verwoorden:

- Binnen alle sectoren zien we veel aandacht voor de vaardigheden analytische vaardigheden en probleemoplossend vermogen. Dit duidt erop dat vrijwel alle opleidingen sterk inzetten op onderzoeksvaardigheden, met name het systematisch analyseren van en oplossingen zoeken voor problemen.

- Gerelateerd aan bovenstaande zien we ook dat veel aandacht wordt besteed aan communicatie- en planningsvaardigheden. Ook wordt binnen alle sectoren ruim aandacht besteedt aan de competentie ethisch besef. Deze drie vaardigheden hangen sterk samen met verschillende aspecten van onderzoek doen in ruime zin.

- De sectoren economie, landbouw en natuurlijke omgeving, en techniek vertonen veel overlap op het vlak van verschillende vaardigheden. Zo zijn de vaardigheden managementvaardigheden, besluitvormingsvaardigheden en ondernemerschapsvaardigheden binnen deze sectoren meer aanwezig dan binnen andere sectoren. Daarnaast scoren zij op veel van de voorgaande vaardigheden gemiddeld hoger dan andere sectoren. Opleidingen in deze sectoren zijn in het algemeen erg gericht op 
project-gebaseerd werken en het (in overleg) verbeteren van (bedrijfs-)processen, waarbij deze vaardigheden in sterkere mate van belang zijn.

- Opleidingen in de sector gezondheidszorg vallen op door hun sterke focus op samenwerken, wat verklaard kan worden door de hoge mate van specialisatie binnen deze sector. Op andere vaardigheden scoort deze sector gemiddeld.

- Binnen de sector gedrag en maatschappij valt juist de sterke focus van vakspecifieke vaardigheden op, terwijl deze sector (beneden)gemiddeld scoort op andere vaardigheden.

- Opvallend is dat er in hbo-profielen, ongeacht de sector, weinig tot geen aandacht is voor het potentieel belang van andere culturen en andere disciplines. Het eerste komt tot uiting in lage scores voor interculturele vaardigheden, waarbij voor de sectoren gedrag \& maatschappij en gezondheidszorg zelfs helemaal geen aanwijzingen zijn gevonden voor de ontwikkeling van deze competentie. Bij interdisciplinaire vaardigheden zien we binnen elke sector wel een aantal opleidingen die deze competentie benoemen, maar ook veel opleidingen die niet aangeven hier aandacht aan te besteden. Er lijkt dus sprake te zijn van een sterkere focus op het aanleren van disciplinaire kennis dan op het integreren van meerdere disciplinaire oogpunten.

- Verder zien we weinig aandacht voor fysieke vaardigheden. Dit hangt echter samen met de nadruk op niet-fysieke vaardigheden binnen het werkniveau waarin studenten op hbo-niveau actief zijn, in tegenstelling tot studenten met een middelbaar of lagere opleiding. Dit komt ook tot uiting in bijvoorbeeld de hoge scores op meer analytische en probleemoplossende vaardigheden. Aangezien een gedeelte van deze fysieke vaardigheden ook het risico loopt op verdringing door bv. robotisering (Autor, Levy \& Murnane, 2003), is de verminderde aanwezigheid van deze vaardigheden daarom onzes inziens niet negatief van invloed op de positie van hbostudenten.

- Als we een vergelijking maken tussen bachelor- en masteropleidingen, valt op dat masteropleidingen nog meer dan bacheloropleidingen inzetten op het ontwikkelen van vaardigheden in het cluster analytische vaardigheden. Dit hangt samen met het meer specialistische karakter van deze opleidingen. Masteropleidingen scoren gelijkaardig als bacheloropleidingen binnen de clusters zelfsturings- en werkgerelateerde vaardigheden, maar scoren lager op het gebied van intermenselijke vaardigheden. Voor dit laatste cluster kan dus gesteld worden dat bacheloropleidingen hier een sterke basis voor leggen, waarop voortgebouwd (en niet uitgebouwd) wordt in de masterfase.

- Uit de vergelijking tussen vaardigheden gemeten in de HBO-Monitor en die gemeten door text-mining scores in hbo-profielen blijkt dat er in veel gevallen sprake is van enige relatie maar dat de verbanden zelden sterk zijn en soms in het geheel afwezig zijn of zelfs negatief. Uit nadere analyse blijkt dat de relatie wel redelijk sterk is bij sommige opleidingen, maar dat er ook opleidingen zijn die op bijna de helft van de vaardigheden een heel andere score vertonen bij afgestudeerden en in het werk dat ze doen dan men op basis van de text-miningscores zou worden verwacht. Dit ligt mogelijk aan een verschil in opzet en doelstelling van de instrumenten waarop de 
maten zijn gebaseerd. We weten immers niet wat het beginniveau was van instromende studenten op deze vaardigheden, en weten onvoldoende welke referentiekader zij hanteerden bij het beoordelen van hun eigen competentieniveau en de vereisten van het werkveld.

\subsection{Beleidsaanbevelingen}

Op basis van bovenstaande bevindingen zijn een aantal aanbevelingen te doen met betrekking tot het ontwikkelen van niet-routinematige vaardigheden in het hoger onderwijs. Ten eerste vinden wij dat niet-routinematige vaardigheden in alle onderzochte opleidingen aan bod komen, maar dat er aanmerkelijke verschillen tussen opleidingen bestaan aangaande welke vaardigheden dit betreft, en de mate waarin deze voorkomen in de profielbeschrijvingen van opleidingen. Het verdient dan ook aanbeveling om met het veld in gesprek te gaan over 1 ) welke niet-routinematige vaardigheden worden gezien als noodzakelijk binnen opleidingen, en 2) hoe sterk deze vaardigheden benadrukt dienen te worden. Het is daarbij voorstelbaar dat over opleidingen heen een aantal vaardigheden kan worden aangemerkt als 'kernvaardigheden', welke terug zouden moeten komen in alle moderne profielen. Andere vaardigheden zouden dan als meer sector/opleidingsspecifiek aangemerkt kunnen worden. Het huidige onderzoek had echter niet tot doel een dergelijke inventarisatie te maken, maar geeft wel inzicht welke vaardigheden nu al veelvoorkomend zijn. Het kan daarom als startpunt voor een dergelijke dialoog worden gebruikt.

Een tweede punt van aandacht is de rol van vaardigheden binnen opleidingen, en hoe deze ingebed worden in de opleidingsprofielen. Het huidige onderzoek laat zien dat er aanmerkelijke verschillen bestaan tussen opleidingen, maar laat ook zien dat een deel van die verschillen kan voorkomen uit de wijze van integratie en de rapportage daarover op het vlak van vaardigheden (zowel routinematige als niet-routinematige). Hierbij valt het vooral op dat sommige opleidingen uitgebreid en gedetailleerd in staat zijn de rol van vaardigheden te verwoorden, terwijl dit bij andere opleidingen slechts op kernachtige wijze gebeurd. Het verdient dan ook aanbeveling om, in samenspraak met het veld, tot een meer geharmoniseerde en gestandaardiseerde wijze van inbedding van vaardigheden te komen. Hierdoor wordt het voor verschillende stakeholders (bv. instellingen, studenten en instanties) duidelijker welke vaardigheden binnen welke opleidingen een rol spelen, en welke niet. Dit kan ook leiden tot meer begrip voor de rol van vaardigheden in opleidingen, daar het explicieter wordt gemaakt welke vaardigheden onderscheiden kunnen worden, en in welke mate een opleiding aandacht besteedt aan specifieke vaardigheden. 


\subsection{Lessen en vooruitzicht}

Dit onderzoek is vernieuwend aangezien het naar ons weten het eerste is dat gebruik maakt van tekstanalyse van onderwijsprofielen om zo de mate waarin opleidingen aandacht besteden aan niet-routinematige vaardigheden te kunnen kwantificeren. Wij trekken een aantal lessen uit dit onderzoek. Ten eerste leidt onze conceptualisering van niet-routinematige vaardigheden tot een zinvolle ranking van opleidingen voor de mate waarin deze opleidingen wel of geen aandacht besteden aan deze vaardigheden. Echter, gaat het hier om een proof of concept, een eerste toepassing van een methode die voor dit doel niet eerder is gebruikt. Vervolgonderzoek zou zich kunnen richten op het verfijnen van onze aanpak en het toepassen in andere domeinen, zoals onderwijsprofielen in het wetenschappelijk onderwijs.

In het verlengde hiervan kan ten tweede worden opgemerkt dat het ontbreken van bepaalde niet-routinematige vaardigheden in de profielen van opleidingen niet hoeft te betekenen dat opleidingen hier geen aandacht aan besteden. Het is denkbaar dat opleidingen hier wel aandacht aan besteden, maar om bepaalde redenen hierover zwijgen in de beschrijving van hun profielen. ${ }^{6}$ Wellicht vinden ze het bijvoorbeeld vanzelfsprekend dat bepaalde vaardigheden in hun opleidingen worden ontwikkeld, en vinden ze het daarom niet nodig om dit expliciet te benoemen. Als opleidingen de betreffende vaardigheden wel belangrijk vinden voor hun studenten, is het echter raadzaam dit explicieter te verwoorden in de beschrijving van het profiel. Daarmee wordt het belang van deze vaardigheden in de opleiding gewaarborgd.

Ten derde, naast profielbeschrijvingen kan wellicht op andere plekken informatie worden gevonden over de mate waarin opleidingen aandacht besteden aan niet-routinematige vaardigheden. Mogelijk zijn bijvoorbeeld sommige vaardigheidsbeschrijvingen verder uitgediept bij de specifieke leerdoelen behorend bij afzonderlijke vakken per bachelor- of masteropleiding, of bij het beschrijven van de gebruikte leervormen in hun onderwijs. Onze methode zou dan ook toegepast kunnen worden op beschrijvingen van aangeboden vakken in het onderwijs en onderwijsmethodes in opleidingen.

$6 \quad$ Het is eveneens denkbaar dat opleidingen wel verwijzen naar bepaalde vaardigheden in hun profielbeschrijving, maar hier in de praktijk weinig aandacht aan besteden. Wij achten dit niet zo waarschijnlijk omdat in dat geval opleidingen in de problemen zouden komen bij accreditatie. 


\section{Literatuur}

Allen, J., Belfi, B., \& Borghans, L. (2020). Is there a rise in the importance of socioemotional skills in the labor market? Evidence from a trend study among college graduates. Frontiers in psychology, 11(1710), 1-13.

Allen, J., \& Belfi, B. (2018). Wie A zegt, zegt ook B? (No. 002). Maastricht University, Research Centre for Education and the Labour Market (ROA).

Allen, J., \& van der Velden, R. (2013). Skills for the 21st century: Implications for Dutch education. Higher education: Recent trends, emerging issues and future outlook, 1-40.

Anderson, R. E. (2008). Implications of the information and knowledge society for education. In International handbook of information technology in primary and secondary education (pp. 5-22). Springer, Boston, MA.

Autor, D. (2015). Why are there still so many jobs? The history and future of workplace automation. Journal of Economic Perspectives, 29(3), 3-30.

Autor, D. H., Levy, F., \& Murnane, R. J. (2003). The skill content of recent technological change: An empirical exploration. The Quarterly journal of economics, 118(4), 1279-1333.

Autor, D. H., \& Price, B. (2013). The changing task composition of the US labor market. An update of Autor, Levy, and Murnane (2003), MIT Paper, June, 21.

Baepler, P., Walker, J. D., \& Driessen, M. (2014). It's not about seat time: Blending, flipping, and efficiency in active learning classrooms. Computers \& Education, 78, 227-236.

Berger, J., \& Milkman, K. L. (2012). What makes online content viral?. Journal of marketing research, 49(2), 192-205.

Blei, D. M. (2012). Probabilistic topic models. Communications of the ACM, 55(4), 77-84.

Borghans, L., Duckworth, A. L., Heckman, J. J., \& Ter Weel, B. (2008). The economics and psychology of cognitive and non-cognitive traits. Journal of Human Resources, 43(4), 972-1059.

Casner-Lotto, J., \& Benner, M. W. (2006). Are they really ready to work? Employers' perspectives on the basic knowledge and applied skills of new entrants to the 21st century US workforce. (Report No. BED-06-Workforce). Conference Board; Partnership for 21st Century Skills; Corporate Voices for Working Families. Society for Human Resource Management.

Deming, D. J. (2017). The growing importance of social skills in the labor market. The Quarterly Journal of Economics, 132(4), 1593-1640.

Duckworth, A. L., \& Yeager, D. S. (2015). Measurement matters: Assessing personal qualities other than cognitive ability for educational purposes. Educational Researcher, 44(4), 237-251.

Ellström, P. E. (1998). The many meanings of occupational competence and qualification. In Key qualifications in work and education (pp. 39-50). Springer, Dordrecht.

Europese Unie (2002). Key competencies: A developing concept in general compulsory education. Brussels: Eurydice.

Goos, M., \& Manning, A. (2007). Lousy and lovely jobs: The rising polarization of work in Britain. The review of economics and statistics, 89(1), 118-133. 
Hartmann, J., Huppertz, J., Schamp, C., \& Heitmann, M. (2019). Comparing automated text classification methods. International Journal of Research in Marketing, 36(1), 20-38.

Law, N., Pelgrum, W. J., \& Plomp, T. (Eds.). (2008). Pedagogy and ICT use in schools around the world: Findings from the IEA SITES 2006 study (Vol. 23). Springer Science \& Business Media.

Lippman, L. H., Ryberg, R., Carney, R., \& Moore, K. A. (2015). Workforce Connections: Key "soft skills" that foster youth workforce success: toward a consensus across fields. Washington, DC: Child Trends.

Ludwig, S., De Ruyter, K., Friedman, M., Brüggen, E. C., Wetzels, M., \& Pfann, G. (2013). More than words: The influence of affective content and linguistic style matches in online reviews on conversion rates. Journal of Marketing, 77(1), 87-103.

Manyika, J., Hunt, D., Nyquist, S., Remes, J., Malhotra, V., Medonca, L., \& Test, S. (2011). Growth and renewal in the United States: Retooling America's economic engine. Journal of Applied Corporate Finance, 23(1), 8-19.

OECD $\left(2018^{\mathrm{a}}\right)$. Social and Emotional Skills for Student Success and Well-Being. New York, NY: Springe 21st Century Skills.

OECD $\left(2018^{b}\right)$. How can you prepare students for the new Global Economy? Paris: OECD/CERI. http://www.oecd.org/site/educeri21st/40756908.pdf

Onderwijsraad (2014). Een eigentijds curriculum. Den Haag: Onderwijsraad.

Pennebaker, J. W., Boyd, R. L., Jordan, K., \& Blackburn, K. (2015). The development and psychometric properties of LIWC2015.

Pang, B., \& Lee, L. (2008). Opinion mining and sentiment analysis. Foundations Trends Information Retrieval 2 (1-2): 1-13.

$\mathrm{R}$ Core Team (2020). R: A language and environment for statistical computing. R Foundation for Statistical Computing, Vienna, Austria. URL https://www.R-project.org/.

Thijs, A., Fisser, P., \& Hoeven, M. van der (2014). 21e -eeuwse vaardigheden in het curriculum van het funderend onderwijs. Enschede: SLO.

Villarroel Ordenes, F., Ludwig, S., De Ruyter, K., Grewal, D., \& Wetzels, M. (2017). Unveiling what is written in the stars: Analyzing explicit, implicit, and discourse patterns of sentiment in social media. Journal of Consumer Research, 43(6), 875-894.

Weinberger, C. (2014). The increasing complementarity between cognitive and social skills. Review of Economics and Statistics, 96(4), 849-861

World Economic Forum (2015). New Vision for Education: Unlocking the Potential of Technology.

Swizerland: Geneva, 1-32. 


\section{Appendix 1: Text-mining scores per cluster, bacheloropleidingen}

\begin{tabular}{|c|c|c|c|c|}
\hline & $\begin{array}{r}\text { Analytische en } \\
\text { Probleemoplossende } \\
\text { vaardigheden }\end{array}$ & $\begin{array}{r}\text { Intermenselijke } \\
\text { vaardigheden }\end{array}$ & $\begin{array}{c}\text { Zelfsturings } \\
\text { vaardigheden }\end{array}$ & $\begin{array}{r}\text { Werkgerelateerde } \\
\text { vaardigheden }\end{array}$ \\
\hline Accountancy & 0,073 & 0,054 & 0,062 & 0,027 \\
\hline Applied Science & 0,056 & 0,044 & 0,079 & 0,023 \\
\hline Bedrijfskunde & 0,075 & 0,019 & 0,029 & 0,039 \\
\hline Bedrijfskunde Agribusiness & 0,062 & 0,039 & 0,043 & 0,026 \\
\hline Beeldende Kunst en Vormgeving & 0,043 & 0,036 & 0,022 & 0,033 \\
\hline $\begin{array}{l}\text { Bestuurskunde } \\
\text { Overheidsmanagement }\end{array}$ & 0,027 & 0,043 & 0,052 & 0,009 \\
\hline Bos en Natuurbeheer & 0,056 & 0,048 & 0,136 & 0,040 \\
\hline Built Environment & 0,049 & 0,044 & 0,087 & 0,011 \\
\hline Business Studies & 0,039 & 0,025 & 0,071 & 0,046 \\
\hline Commerciële Economie & 0,073 & 0,040 & 0,068 & 0,009 \\
\hline Communicatie & 0,057 & 0,106 & 0,049 & 0,027 \\
\hline $\begin{array}{l}\text { Communication and Multimedia } \\
\text { Design }\end{array}$ & 0,088 & 0,037 & 0,070 & 0,048 \\
\hline Creative Business & 0,098 & 0,030 & 0,075 & 0,039 \\
\hline Creative Technologies & 0,066 & 0,044 & 0,057 & 0,060 \\
\hline Dans & 0,047 & 0,036 & 0,029 & 0,042 \\
\hline Dier en Veehouderij & 0,050 & 0,054 & 0,047 & 0,019 \\
\hline Diermanagement & 0,067 & 0,063 & 0,087 & 0,020 \\
\hline Diëtist & 0,052 & 0,066 & 0,032 & 0,035 \\
\hline Educatie en Kennismanagement & 0,069 & 0,037 & 0,065 & 0,035 \\
\hline Elektrotechniek & 0,050 & 0,031 & 0,059 & 0,049 \\
\hline Engineering & 0,051 & 0,034 & 0,069 & 0,050 \\
\hline Ergotherapie & 0,066 & 0,028 & 0,042 & 0,014 \\
\hline Facility Management & 0,030 & 0,022 & 0,067 & 0,045 \\
\hline Film en Televisie & 0,032 & 0,028 & 0,024 & 0,024 \\
\hline Finance and Control & 0,081 & 0,041 & 0,095 & 0,088 \\
\hline Finance Tax \& Advice & 0,046 & 0,015 & 0,066 & 0,015 \\
\hline Food Design \& Innovation & 0,041 & 0,018 & 0,032 & 0,069 \\
\hline Food en Marketing & 0,080 & 0,010 & 0,061 & 0,016 \\
\hline Fysiotherapie & 0,026 & 0,022 & 0,061 & 0,039 \\
\hline Geo Media \& Design & 0,083 & 0,020 & 0,024 & 0,068 \\
\hline
\end{tabular}




\begin{tabular}{|c|c|c|c|c|}
\hline Hospitality Management & 0,088 & 0,025 & 0,050 & 0,038 \\
\hline Huidtherapie & 0,010 & 0,050 & 0,060 & 0,050 \\
\hline Human Resource Management & 0,049 & 0,020 & 0,066 & 0,033 \\
\hline ICT & 0,067 & 0,005 & 0,046 & 0,054 \\
\hline Informatieprofessional & 0,051 & 0,031 & 0,035 & 0,067 \\
\hline Integrale Veiligheidskunde & 0,050 & 0,048 & 0,040 & 0,031 \\
\hline International Business & 0,060 & 0,039 & 0,056 & 0,017 \\
\hline Jeugdzorg & 0,010 & 0,020 & 0,020 & 0,020 \\
\hline Journalistiek & 0,050 & 0,021 & 0,047 & 0,009 \\
\hline Kunst en Economie & 0,100 & 0,028 & 0,048 & 0,045 \\
\hline Kunstvak Docent & 0,060 & 0,044 & 0,015 & 0,030 \\
\hline Kust- en Zeemanagement & 0,028 & 0,111 & 0,083 & 0,000 \\
\hline Land en Watermanagement & 0,048 & 0,032 & 0,085 & 0,069 \\
\hline Leisure \& Event Management & 0,035 & 0,045 & 0,048 & 0,027 \\
\hline Logistiek & 0,094 & 0,036 & 0,049 & 0,040 \\
\hline Logopedie & 0,060 & 0,082 & 0,107 & 0,034 \\
\hline Management in de Zorg & 0,046 & 0,049 & 0,044 & 0,025 \\
\hline Management van de Leefomgeving & 0,092 & 0,037 & 0,055 & 0,119 \\
\hline Maritieme Techniek & 0,065 & 0,015 & 0,055 & 0,073 \\
\hline Maritime Operations & 0,083 & 0,031 & 0,048 & 0,009 \\
\hline MBRT & 0,056 & 0,051 & 0,047 & 0,018 \\
\hline Medische Hulpverlening & 0,012 & 0,031 & 0,031 & 0,036 \\
\hline Milieukunde & 0,078 & 0,014 & 0,071 & 0,078 \\
\hline Muziek & 0,048 & 0,029 & 0,033 & 0,010 \\
\hline Nursing & 0,023 & 0,033 & 0,040 & 0,023 \\
\hline Oefentherapie & 0,070 & 0,041 & 0,061 & 0,042 \\
\hline $\begin{array}{l}\text { Ondernemerschap en } \\
\text { Retailmanagement }\end{array}$ & 0,070 & 0,078 & 0,070 & 0,016 \\
\hline Opleidingskunde & 0,052 & 0,052 & 0,056 & 0,045 \\
\hline Optometrie & 0,034 & 0,023 & 0,049 & 0,027 \\
\hline Oriëntaalse Talen en Communicatie & 0,084 & 0,067 & 0,056 & 0,017 \\
\hline Orthoptist & 0,031 & 0,046 & 0,019 & 0,011 \\
\hline PABO & 0,062 & 0,038 & 0,030 & 0,028 \\
\hline Pedagogiek & 0,044 & 0,022 & 0,015 & 0,052 \\
\hline Rechten & 0,070 & 0,030 & 0,038 & 0,029 \\
\hline Sociaal Juridische Dienstverlening & 0,053 & 0,036 & 0,024 & 0,016 \\
\hline Sociaal pedagogische Hulpverlening & 0,058 & 0,034 & 0,046 & 0,055 \\
\hline Sociaal Werk & 0,047 & 0,045 & 0,029 & 0,068 \\
\hline Sportkunde & 0,064 & 0,033 & 0,055 & 0,022 \\
\hline Technische Bedrijfskunde & 0,034 & 0,029 & 0,101 & 0,034 \\
\hline Theater & 0,040 & 0,038 & 0,023 & 0,030 \\
\hline Theoloog & 0,021 & 0,048 & 0,021 & 0,021 \\
\hline Toegepaste Biologie & 0,099 & 0,048 & 0,057 & 0,045 \\
\hline
\end{tabular}




\begin{tabular}{|c|c|c|c|c|}
\hline Toegepaste Gerontologie & 0,022 & 0,025 & 0,025 & 0,033 \\
\hline Toegepaste Psychologie & 0,083 & 0,023 & 0,072 & 0,029 \\
\hline Toegepaste Wiskunde & 0,052 & 0,008 & 0,084 & 0,060 \\
\hline Tolk Nederlandse Gebarentaal & 0,003 & 0,066 & 0,069 & 0,045 \\
\hline Tourism Management & 0,057 & 0,028 & 0,081 & 0,014 \\
\hline Trend Research & 0,088 & 0,016 & 0,057 & 0,057 \\
\hline Tuin en Landschapsinrichting & 0,064 & 0,035 & 0,152 & 0,035 \\
\hline Tuinbouw en Akkerbouw & 0,042 & 0,039 & 0,055 & 0,013 \\
\hline Tweedegraads Aardrijkskunde & 0,030 & 0,012 & 0,012 & 0,016 \\
\hline Tweedegraads Biologie & 0,021 & 0,040 & 0,011 & 0,009 \\
\hline Tweedegraads Consumptieve Techniek & 0,028 & 0,060 & 0,024 & 0,028 \\
\hline Tweedegraads Duits & 0,037 & 0,064 & 0,028 & 0,023 \\
\hline Tweedegraads Economie & 0,054 & 0,021 & 0,023 & 0,009 \\
\hline Tweedegraads Engels & 0,038 & 0,042 & 0,021 & 0,017 \\
\hline Tweedegraads Frans & 0,039 & 0,051 & 0,023 & 0,013 \\
\hline Tweedegraads Fries & 0,039 & 0,026 & 0,015 & 0,009 \\
\hline Tweedegraads Geschiedenis & 0,027 & 0,032 & 0,011 & 0,016 \\
\hline Tweedegraads Gezondheidszorg & 0,031 & 0,030 & 0,023 & 0,020 \\
\hline $\begin{array}{l}\text { Tweedegraads Godsdienst en } \\
\text { Levensbeschouwing }\end{array}$ & 0,056 & 0,020 & 0,020 & 0,009 \\
\hline Tweedegraads Islamgodsdienst & 0,031 & 0,007 & 0,012 & 0,007 \\
\hline Tweedegraads Maatschappijleer & 0,014 & 0,009 & 0,027 & 0,002 \\
\hline Tweedegraads Nederlands & 0,042 & 0,041 & 0,011 & 0,009 \\
\hline Tweedegraads 0mgangskunde & 0,028 & 0,130 & 0,028 & 0,020 \\
\hline Tweedegraads Scheikunde & 0,025 & 0,043 & 0,015 & 0,010 \\
\hline Tweedegraads Spaans & 0,036 & 0,037 & 0,016 & 0,011 \\
\hline Tweedegraads Wiskunde & 0,081 & 0,019 & 0,030 & 0,027 \\
\hline Vaktherapeutische Beroepen & 0,044 & 0,047 & 0,050 & 0,152 \\
\hline Vastgoed en Makelaardij & 0,065 & 0,019 & 0,096 & 0,042 \\
\hline Voedingsmiddelentechnologie & 0,062 & 0,016 & 0,070 & 0,016 \\
\hline Werktuigbouwkunde & 0,036 & 0,004 & 0,053 & 0,036 \\
\hline
\end{tabular}





\section{Appendix 2: Text-mining scores per cluster, masteropleidingen}

\begin{tabular}{|c|c|c|c|c|}
\hline & $\begin{array}{r}\text { Analytische en } \\
\text { Probleemoplossende } \\
\text { vaardigheden }\end{array}$ & $\begin{array}{l}\text { Intermenselijke } \\
\text { vaardigheden }\end{array}$ & $\begin{array}{c}\text { Zelfsturings } \\
\text { vaardigheden }\end{array}$ & $\begin{array}{l}\text { Werkgerelateerde } \\
\text { vaardigheden }\end{array}$ \\
\hline Beeldende kunst en Vormgeving & 0,026 & 0,034 & 0,042 & 0,037 \\
\hline Eerstegraads Aardrijkskunde & 0,056 & 0,037 & 0,025 & 0,035 \\
\hline Eerstegraads Algemene Economie & 0,013 & 0,045 & 0,025 & 0,020 \\
\hline Eerstegraads Biologie & 0,065 & 0,020 & 0,065 & 0,032 \\
\hline Eerstegraads Duits & 0,095 & 0,024 & 0,030 & 0,033 \\
\hline Eerstegraads Engels & 0,051 & 0,030 & 0,037 & 0,019 \\
\hline Eerstegraads Frans & 0,025 & 0,036 & 0,051 & 0,033 \\
\hline Eerstegraads Fries & 0,056 & 0,049 & 0,024 & 0,013 \\
\hline Eerstegraads Geschiedenis & 0,060 & 0,038 & 0,032 & 0,010 \\
\hline Eerstegraads Godsdienst & 0,042 & 0,031 & 0,013 & 0,016 \\
\hline Eerstegraads Lichamelijke Opvoeding & 0,066 & 0,040 & 0,019 & 0,008 \\
\hline Eerstegraads Maatschappijleer & 0,076 & 0,006 & 0,016 & 0,013 \\
\hline Eerstegraads Nederlands & 0,049 & 0,032 & 0,020 & 0,014 \\
\hline Eerstegraads Scheikunde & 0,056 & 0,031 & 0,031 & 0,024 \\
\hline Eerstegraads Wiskunde & 0,060 & 0,043 & 0,020 & 0,026 \\
\hline Interieur Architectuur & 0,022 & 0,042 & 0,015 & 0,013 \\
\hline Kunsteducatie & 0,047 & 0,026 & 0,010 & 0,007 \\
\hline Master of Music & 0,077 & 0,043 & 0,021 & 0,017 \\
\hline Physician Assistant & 0,032 & 0,010 & 0,029 & 0,010 \\
\hline Speciale Onderwijszorg & 0,046 & 0,018 & 0,013 & 0,011 \\
\hline Verpleegkundig Specialist & 0,084 & 0,017 & 0,023 & 0,018 \\
\hline
\end{tabular}





\section{Appendix 3: Text-mining scores per subcluster, bacheloropleidingen}

\begin{tabular}{|c|c|c|c|c|c|c|c|c|c|c|}
\hline & \multicolumn{5}{|c|}{$\begin{array}{l}\text { Hoofdcluster A: Analytische en } \\
\text { probleemoplossende vaardigheden }\end{array}$} & \multicolumn{5}{|c|}{$\begin{array}{l}\text { Hoofdcluster B: Intermenselijke } \\
\text { vaardigheden }\end{array}$} \\
\hline & 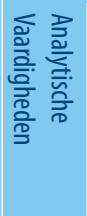 & 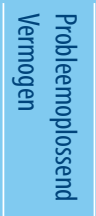 & 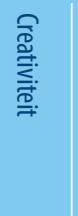 & 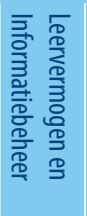 & 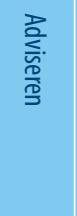 & 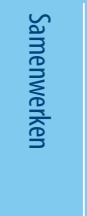 & 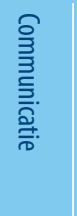 & 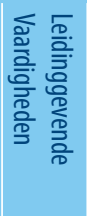 & 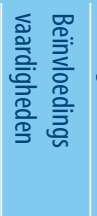 & 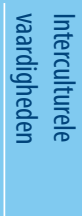 \\
\hline Accountancy & 0,042 & 0,027 & 0,000 & 0,004 & 0,000 & 0,019 & 0,019 & 0,004 & 0,012 & 0,000 \\
\hline Applied Science & 0,023 & 0,020 & 0,003 & 0,005 & 0,006 & 0,002 & 0,017 & 0,023 & 0,003 & 0,000 \\
\hline Bedrijfskunde & 0,044 & 0,022 & 0,005 & 0,005 & 0,000 & 0,002 & 0,007 & 0,005 & 0,005 & 0,000 \\
\hline Bedrijfskunde Agribusiness & 0,019 & 0,028 & 0,014 & 0,000 & 0,002 & 0,016 & 0,012 & 0,005 & 0,003 & 0,003 \\
\hline $\begin{array}{l}\text { Beeldende Kunst en } \\
\text { Vormgeving }\end{array}$ & 0,032 & 0,005 & 0,006 & 0,000 & 0,000 & 0,010 & 0,021 & 0,004 & 0,002 & 0,000 \\
\hline $\begin{array}{l}\text { Bestuurskunde } \\
\text { Overheidsmanagement }\end{array}$ & 0,018 & 0,006 & 0,000 & 0,003 & 0,000 & 0,006 & 0,024 & 0,009 & 0,003 & 0,000 \\
\hline Bos en Natuurbeheer & 0,008 & 0,024 & 0,008 & 0,008 & 0,008 & 0,016 & 0,032 & 0,000 & 0,000 & 0,000 \\
\hline Built Environment & 0,016 & 0,022 & 0,005 & 0,000 & 0,005 & 0,011 & 0,033 & 0,000 & 0,000 & 0,000 \\
\hline Business Studies & 0,025 & 0,005 & 0,009 & 0,000 & 0,000 & 0,007 & 0,014 & 0,005 & 0,000 & 0,000 \\
\hline Commerciële Economie & 0,031 & 0,021 & 0,019 & 0,002 & 0,000 & 0,012 & 0,021 & 0,007 & 0,000 & 0,000 \\
\hline Communicatie & 0,022 & 0,011 & 0,025 & 0,000 & 0,000 & 0,008 & 0,084 & 0,014 & 0,000 & 0,000 \\
\hline $\begin{array}{l}\text { Communication and } \\
\text { Multimedia Design }\end{array}$ & 0,046 & 0,029 & 0,003 & 0,005 & 0,005 & 0,011 & 0,014 & 0,005 & 0,003 & 0,003 \\
\hline Creative Business & 0,036 & 0,028 & 0,030 & 0,002 & 0,001 & 0,010 & 0,012 & 0,003 & 0,004 & 0,001 \\
\hline Creative Technologies & 0,022 & 0,019 & 0,022 & 0,003 & 0,000 & 0,013 & 0,022 & 0,006 & 0,003 & 0,000 \\
\hline Dans & 0,031 & 0,010 & 0,005 & 0,000 & 0,000 & 0,010 & 0,016 & 0,003 & 0,003 & 0,005 \\
\hline Dier en Veehouderij & 0,017 & 0,017 & 0,005 & 0,002 & 0,009 & 0,009 & 0,033 & 0,009 & 0,000 & 0,002 \\
\hline Diermanagement & 0,039 & 0,012 & 0,000 & 0,000 & 0,016 & 0,012 & 0,039 & 0,004 & 0,008 & 0,000 \\
\hline Diëtist & 0,023 & 0,021 & 0,000 & 0,000 & 0,008 & 0,018 & 0,041 & 0,003 & 0,003 & 0,000 \\
\hline $\begin{array}{l}\text { Educatie en } \\
\text { Kennismanagement }\end{array}$ & 0,032 & 0,015 & 0,004 & 0,017 & 0,001 & 0,004 & 0,019 & 0,012 & 0,001 & 0,000 \\
\hline Elektrotechniek & 0,025 & 0,016 & 0,003 & 0,003 & 0,004 & 0,004 & 0,008 & 0,013 & 0,004 & 0,001 \\
\hline Engineering & 0,029 & 0,013 & 0,002 & 0,003 & 0,005 & 0,005 & 0,014 & 0,006 & 0,006 & 0,002 \\
\hline Ergotherapie & 0,021 & 0,024 & 0,003 & 0,003 & 0,014 & 0,014 & 0,003 & 0,010 & 0,000 & 0,000 \\
\hline Facility Management & 0,007 & 0,015 & 0,003 & 0,003 & 0,002 & 0,007 & 0,010 & 0,002 & 0,003 & 0,000 \\
\hline Film en Televisie & 0,013 & 0,007 & 0,011 & 0,001 & 0,000 & 0,012 & 0,011 & 0,003 & 0,003 & 0,000 \\
\hline
\end{tabular}




\begin{tabular}{|c|c|c|c|c|c|c|c|c|c|c|}
\hline Finance and Control & 0,034 & 0,020 & 0,000 & 0,007 & 0,020 & 0,014 & 0,020 & 0,000 & 0,000 & 0,007 \\
\hline Finance Tax \& Advice & 0,015 & 0,000 & 0,000 & 0,000 & 0,030 & 0,000 & 0,015 & 0,000 & 0,000 & 0,000 \\
\hline Food Design \& Innovation & 0,005 & 0,018 & 0,014 & 0,005 & 0,000 & 0,009 & 0,009 & 0,000 & 0,000 & 0,000 \\
\hline Food en Marketing & 0,048 & 0,010 & 0,010 & 0,000 & 0,013 & 0,000 & 0,006 & 0,000 & 0,003 & 0,000 \\
\hline Fysiotherapie & 0,013 & 0,009 & 0,004 & 0,000 & 0,000 & 0,009 & 0,013 & 0,000 & 0,000 & 0,000 \\
\hline Geo Media \& Design & 0,049 & 0,020 & 0,005 & 0,007 & 0,002 & 0,002 & 0,015 & 0,002 & 0,000 & 0,000 \\
\hline Hospitality Management & 0,056 & 0,019 & 0,006 & 0,006 & 0,000 & 0,000 & 0,006 & 0,013 & 0,006 & 0,000 \\
\hline Huidtherapie & 0,000 & 0,005 & 0,000 & 0,000 & 0,005 & 0,010 & 0,000 & 0,040 & 0,000 & 0,000 \\
\hline Human Resource Management & 0,031 & 0,013 & 0,000 & 0,003 & 0,003 & 0,010 & 0,005 & 0,003 & 0,003 & 0,000 \\
\hline ICT & 0,035 & 0,016 & 0,003 & 0,008 & 0,005 & 0,000 & 0,003 & 0,000 & 0,003 & 0,000 \\
\hline Informatieprofessional & 0,028 & 0,004 & 0,000 & 0,000 & 0,020 & 0,008 & 0,024 & 0,000 & 0,000 & 0,000 \\
\hline Integrale Veiligheidskunde & 0,029 & 0,012 & 0,007 & 0,000 & 0,002 & 0,007 & 0,019 & 0,014 & 0,005 & 0,002 \\
\hline International Business & 0,039 & 0,009 & 0,013 & 0,000 & 0,000 & 0,004 & 0,022 & 0,000 & 0,004 & 0,009 \\
\hline Jeugdzorg & 0,000 & 0,010 & 0,000 & 0,000 & 0,000 & 0,000 & 0,000 & 0,000 & 0,020 & 0,000 \\
\hline Journalistiek & 0,027 & 0,012 & 0,012 & 0,000 & 0,000 & 0,006 & 0,012 & 0,000 & 0,003 & 0,000 \\
\hline Kunst en Economie & 0,019 & 0,022 & 0,056 & 0,004 & 0,000 & 0,009 & 0,009 & 0,006 & 0,004 & 0,000 \\
\hline Kunstvak Docent & 0,029 & 0,023 & 0,005 & 0,005 & 0,000 & 0,008 & 0,014 & 0,011 & 0,003 & 0,009 \\
\hline Kust- en Zeemanagement & 0,000 & 0,028 & 0,000 & 0,000 & 0,000 & 0,056 & 0,028 & 0,028 & 0,000 & 0,000 \\
\hline Land en Watermanagement & 0,032 & 0,011 & 0,000 & 0,005 & 0,000 & 0,005 & 0,021 & 0,000 & 0,005 & 0,000 \\
\hline Leisure \& Event Management & 0,017 & 0,005 & 0,010 & 0,002 & 0,001 & 0,014 & 0,017 & 0,009 & 0,004 & 0,001 \\
\hline Logistiek & 0,072 & 0,009 & 0,000 & 0,009 & 0,004 & 0,000 & 0,004 & 0,031 & 0,000 & 0,000 \\
\hline Logopedie & 0,039 & 0,013 & 0,004 & 0,000 & 0,004 & 0,030 & 0,052 & 0,000 & 0,000 & 0,000 \\
\hline Management in de Zorg & 0,019 & 0,014 & 0,009 & 0,004 & 0,000 & 0,023 & 0,007 & 0,014 & 0,005 & 0,000 \\
\hline $\begin{array}{l}\text { Management van de } \\
\text { Leefomgeving }\end{array}$ & 0,037 & 0,000 & 0,055 & 0,000 & 0,000 & 0,009 & 0,018 & 0,009 & 0,000 & 0,000 \\
\hline Maritieme Techniek & 0,038 & 0,015 & 0,004 & 0,002 & 0,006 & 0,010 & 0,002 & 0,000 & 0,002 & 0,000 \\
\hline Maritime Operations & 0,022 & 0,057 & 0,000 & 0,004 & 0,000 & 0,004 & 0,022 & 0,004 & 0,000 & 0,000 \\
\hline MBRT & 0,015 & 0,027 & 0,006 & 0,004 & 0,005 & 0,016 & 0,021 & 0,015 & 0,000 & 0,000 \\
\hline Medische Hulpve & 0,010 & 0,002 & 0,000 & 0,000 & 0,000 & 0,010 & 0,012 & 0,005 & 0,005 & 0,000 \\
\hline Milieukunde & 0,035 & 0,028 & 0,000 & 0,000 & 0,014 & 0,007 & 0,007 & 0,000 & 0,000 & 0,000 \\
\hline Muziek & 0,027 & 0,0 & 0,006 & 0,002 & 0,000 & 0,004 & 0,019 & 0,004 & 0,000 & 0,002 \\
\hline Nursing & 0,010 & 0,010 & 0,003 & 0,000 & 0,000 & 0,017 & 0,007 & 0,007 & 0,003 & 0,000 \\
\hline Oefentherapie & 0,036 & 0,013 & 0,004 & 0,013 & 0,003 & 0,017 & 0,013 & 0,003 & 0,007 & 0,000 \\
\hline $\begin{array}{l}\text { Ondernemerschap en } \\
\text { Retailmanagement }\end{array}$ & 0,039 & 0,016 & 0,016 & 0,000 & 0,000 & 0,023 & 0,031 & 0,016 & 0,008 & 0,000 \\
\hline Opleidingskunde & 0,022 & 0,006 & 0,000 & 0,017 & 0,007 & 0,011 & 0,019 & 0,019 & 0,004 & 0,000 \\
\hline Optometrie & 0,015 & 0,008 & 0,004 & 0,000 & 0,008 & 0,000 & 0,011 & 0,008 & 0,004 & 0,000 \\
\hline $\begin{array}{l}\text { Oriëntaalse Talen en } \\
\text { Communicatie }\end{array}$ & 0,028 & 0,028 & 0,000 & 0,000 & 0,028 & 0,000 & 0,056 & 0,000 & 0,000 & 0,011 \\
\hline Orthoptist & 0,019 & 0,007 & 0,000 & 0,005 & 0,000 & 0,008 & 0,027 & 0,009 & 0,001 & 0,000 \\
\hline PABO & 0,026 & 0,010 & 0,003 & 0,023 & 0,001 & 0,010 & 0,015 & 0,010 & 0,003 & 0,000 \\
\hline Pedagogiek & 0,007 & 0,030 & 0,000 & 0,007 & 0,000 & 0,007 & 0,000 & 0,015 & 0,000 & 0,000 \\
\hline Rechten & 0,033 & 0,020 & 0,004 & 0,001 & 0,012 & 0,002 & 0,020 & 0,001 & 0,006 & 0,000 \\
\hline
\end{tabular}




\begin{tabular}{|c|c|c|c|c|c|c|c|c|c|c|}
\hline $\begin{array}{l}\text { Sociaal Juridische } \\
\text { Dienstverlening }\end{array}$ & 0,018 & 0,021 & 0,001 & 0,000 & 0,013 & 0,003 & 0,017 & 0,008 & 0,007 & 0,000 \\
\hline $\begin{array}{l}\text { Sociaal pedagogische } \\
\text { Hulpverlening }\end{array}$ & 0,021 & 0,021 & 0,015 & 0,000 & 0,000 & 0,009 & 0,018 & 0,006 & 0,000 & 0,000 \\
\hline Sociaal Werk & 0,011 & 0,021 & 0,007 & 0,005 & 0,003 & 0,010 & 0,018 & 0,007 & 0,009 & 0,000 \\
\hline Sportkunde & 0,030 & 0,022 & 0,000 & 0,000 & 0,011 & 0,000 & 0,011 & 0,022 & 0,000 & 0,000 \\
\hline Technische Bedrijfskunde & 0,013 & 0,013 & 0,000 & 0,000 & 0,008 & 0,004 & 0,017 & 0,004 & 0,004 & 0,000 \\
\hline Theater & 0,025 & 0,012 & 0,002 & 0,000 & 0,000 & 0,008 & 0,018 & 0,002 & 0,002 & 0,007 \\
\hline Theoloog & 0,011 & 0,005 & 0,005 & 0,000 & 0,000 & 0,005 & 0,021 & 0,021 & 0,000 & 0,000 \\
\hline Toegepaste Biologie & 0,038 & 0,048 & 0,003 & 0,003 & 0,006 & 0,013 & 0,035 & 0,000 & 0,000 & 0,000 \\
\hline Toegepaste Gerontologie & 0,017 & 0,006 & 0,000 & 0,000 & 0,000 & 0,019 & 0,006 & 0,000 & 0,000 & 0,000 \\
\hline Toegepaste Psychologie & 0,040 & 0,032 & 0,003 & 0,006 & 0,003 & 0,006 & 0,006 & 0,000 & 0,011 & 0,000 \\
\hline Toegepaste Wiskunde & 0,032 & 0,012 & 0,000 & 0,004 & 0,004 & 0,004 & 0,000 & 0,004 & 0,000 & 0,000 \\
\hline Tolk Nederlandse Gebarentaal & 0,000 & 0,003 & 0,000 & 0,000 & 0,000 & 0,048 & 0,013 & 0,003 & 0,003 & 0,000 \\
\hline Tourism Management & 0,028 & 0,014 & 0,014 & 0,000 & 0,002 & 0,002 & 0,016 & 0,006 & 0,000 & 0,004 \\
\hline Trend Research & 0,021 & 0,016 & 0,036 & 0,000 & 0,016 & 0,000 & 0,016 & 0,000 & 0,000 & 0,000 \\
\hline Tuin en Landschapsinrichting & 0,018 & 0,029 & 0,006 & 0,006 & 0,006 & 0,006 & 0,023 & 0,006 & 0,000 & 0,000 \\
\hline Tuinbouw en Akkerbouw & 0,010 & 0,018 & 0,003 & 0,000 & 0,010 & 0,008 & 0,021 & 0,008 & 0,000 & 0,003 \\
\hline Tweedegraads Aardrijkskunde & 0,013 & 0,004 & 0,001 & 0,011 & 0,000 & 0,001 & 0,003 & 0,003 & 0,003 & 0,000 \\
\hline Tweedegraads Biologie & 0,017 & 0,003 & 0,000 & 0,000 & 0,000 & 0,003 & 0,026 & 0,009 & 0,002 & 0,000 \\
\hline $\begin{array}{l}\text { Tweedegraads Consumptieve } \\
\text { Techniek }\end{array}$ & 0,017 & 0,004 & 0,002 & 0,006 & 0,000 & 0,004 & 0,026 & 0,028 & 0,002 & 0,000 \\
\hline Tweedegraads Duits & 0,033 & 0,003 & 0,000 & 0,001 & 0,001 & 0,001 & 0,046 & 0,007 & 0,006 & 0,006 \\
\hline Tweedegraads Economie & 0,051 & 0,000 & 0,002 & 0,000 & 0,001 & 0,002 & 0,010 & 0,006 & 0,003 & 0,000 \\
\hline Tweedegraads Engels & 0,029 & 0,002 & 0,000 & 0,006 & 0,001 & 0,002 & 0,028 & 0,005 & 0,004 & 0,003 \\
\hline Tweedegraads Frans & 0,031 & 0,004 & 0,000 & 0,003 & 0,001 & 0,002 & 0,035 & 0,007 & 0,005 & 0,003 \\
\hline Tweedegraads Fries & 0,022 & 0,003 & 0,000 & 0,013 & 0,001 & 0,001 & 0,016 & 0,006 & 0,001 & 0,002 \\
\hline Tweedegraads Geschiedenis & 0,023 & 0,002 & 0,001 & 0,000 & 0,000 & 0,000 & 0,017 & 0,012 & 0,003 & 0,000 \\
\hline Tweedegraads Gezondheidszorg & 0,022 & 0,002 & 0,000 & 0,008 & 0,000 & 0,002 & 0,005 & 0,015 & 0,007 & 0,000 \\
\hline $\begin{array}{l}\text { Tweedegraads Godsdienst en } \\
\text { Levensbeschouwing }\end{array}$ & 0,056 & 0,000 & 0,000 & 0,000 & 0,000 & 0,000 & 0,017 & 0,001 & 0,003 & 0,000 \\
\hline Tweedegraads Islamgodsdienst & 0,031 & 0,000 & 0,000 & 0,000 & 0,000 & 0,000 & 0,004 & 0,002 & 0,001 & 0,000 \\
\hline Tweedegraads Maatschappijleer & 0,012 & 0,002 & 0,000 & 0,000 & 0,000 & 0,000 & 0,004 & 0,000 & 0,004 & 0,000 \\
\hline Tweedegraads Nederlands & 0,030 & 0,001 & 0,001 & 0,010 & 0,000 & 0,003 & 0,037 & 0,000 & 0,000 & 0,000 \\
\hline Tweedegraads Omgangskunde & 0,016 & 0,001 & 0,001 & 0,009 & 0,000 & 0,005 & 0,053 & 0,043 & 0,029 & 0,000 \\
\hline Tweedegraads Scheikunde & 0,024 & 0,001 & 0,000 & 0,000 & 0,000 & 0,001 & 0,024 & 0,017 & 0,000 & 0,000 \\
\hline Tweedegraads Spaans & 0,025 & 0,005 & 0,000 & 0,006 & 0,000 & 0,001 & 0,023 & 0,006 & 0,004 & 0,004 \\
\hline Tweedegraads Wiskunde & 0,062 & 0,015 & 0,000 & 0,004 & 0,000 & 0,000 & 0,015 & 0,001 & 0,002 & 0,000 \\
\hline Vaktherapeutische Beroepen & 0,022 & 0,011 & 0,006 & 0,006 & 0,000 & 0,006 & 0,022 & 0,000 & 0,019 & 0,000 \\
\hline Vastgoed en Makelaardij & 0,031 & 0,018 & 0,004 & 0,000 & 0,011 & 0,002 & 0,008 & 0,004 & 0,004 & 0,000 \\
\hline Voedingsmiddelentechnologie & 0,016 & 0,031 & 0,000 & 0,000 & 0,016 & 0,000 & 0,000 & 0,016 & 0,000 & 0,000 \\
\hline Werktuigbouwkunde & 0,018 & 0,004 & 0,000 & 0,000 & 0,014 & 0,000 & 0,000 & 0,004 & 0,000 & 0,000 \\
\hline
\end{tabular}




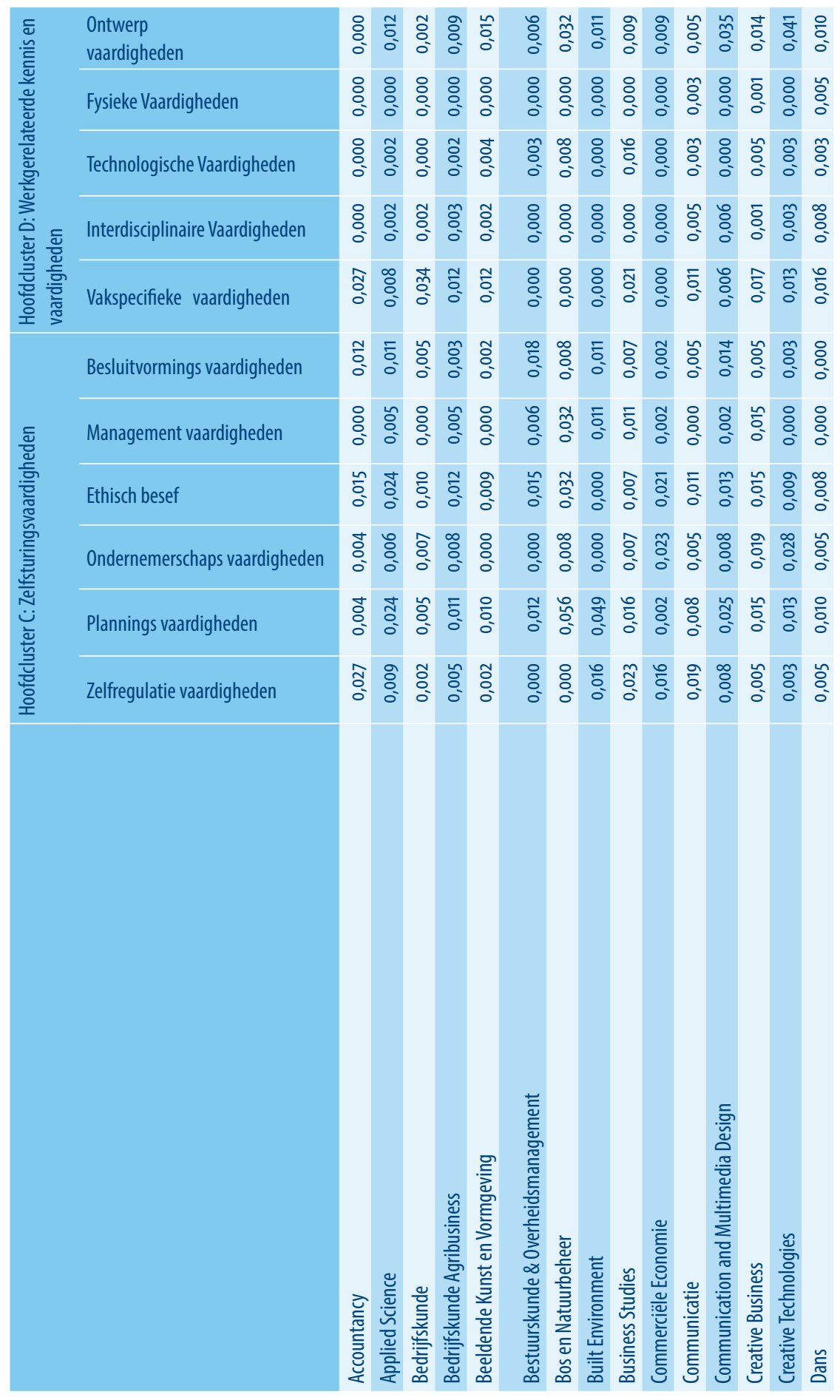




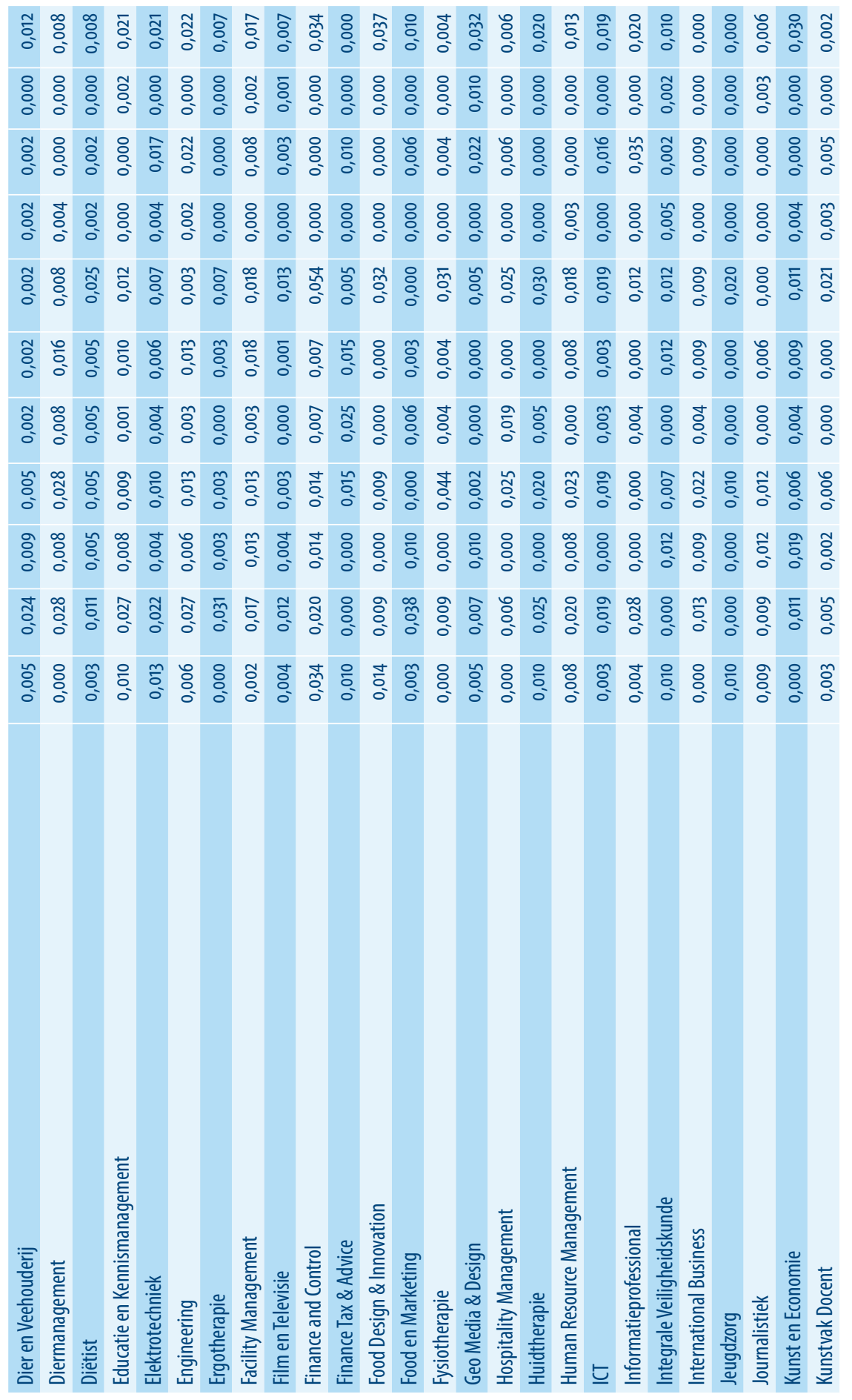




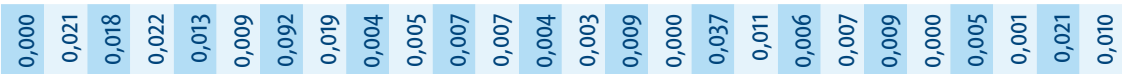

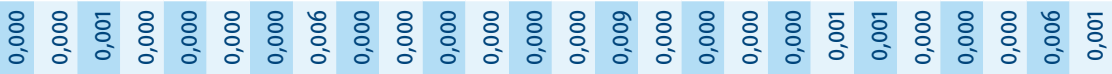

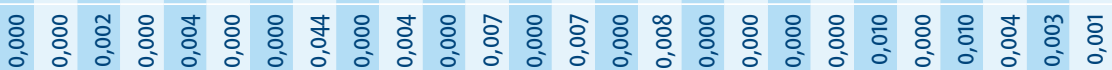

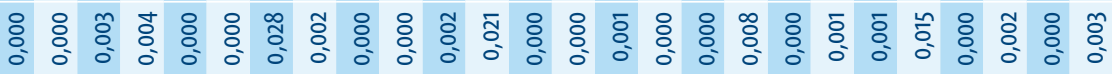

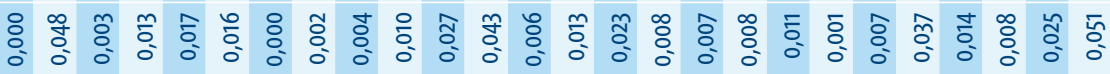

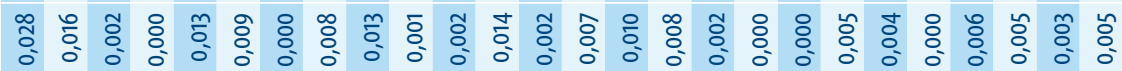

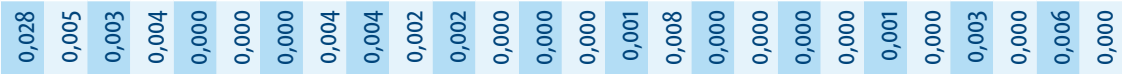 总

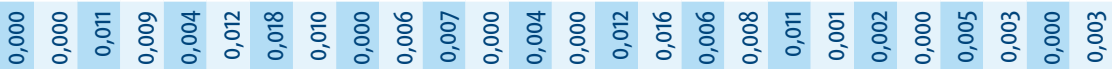

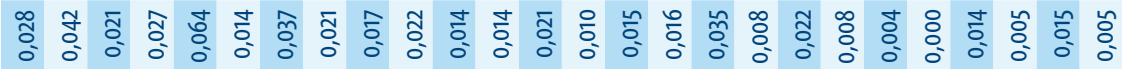 哭}

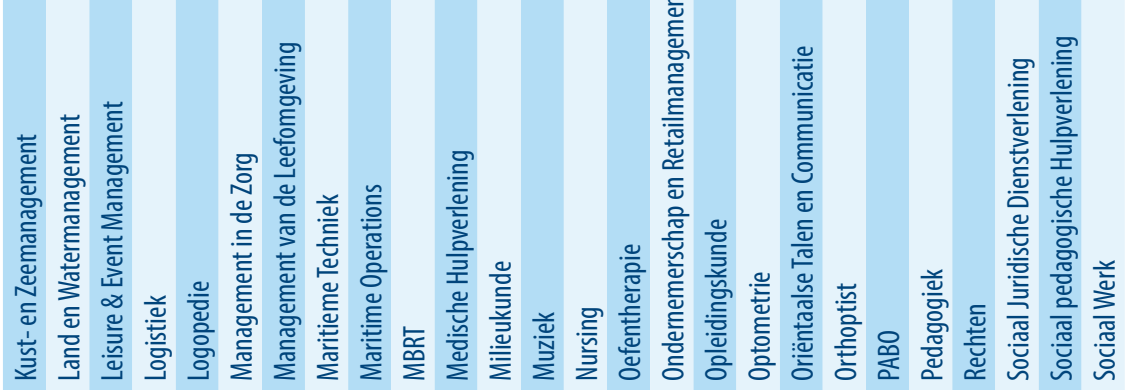




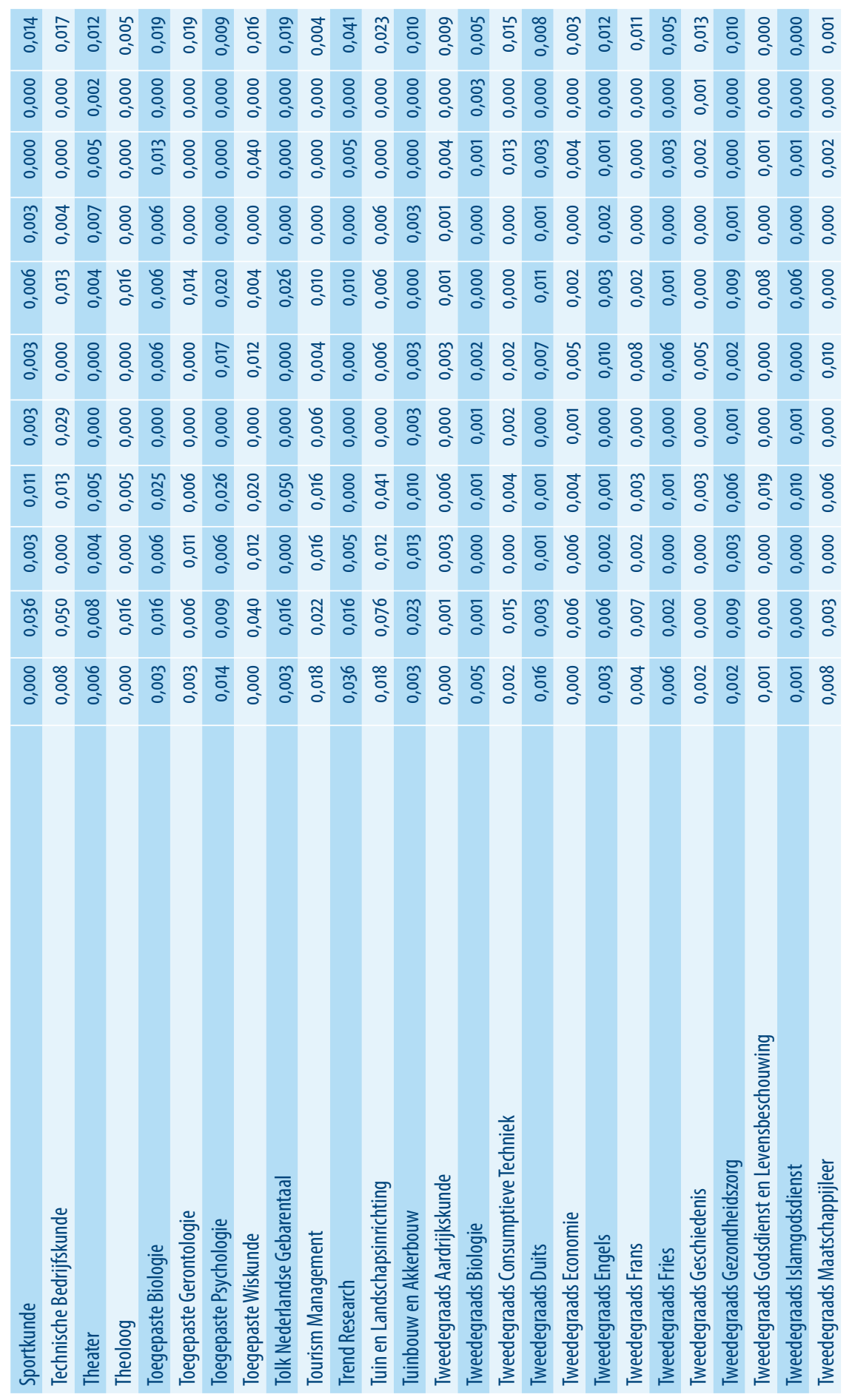




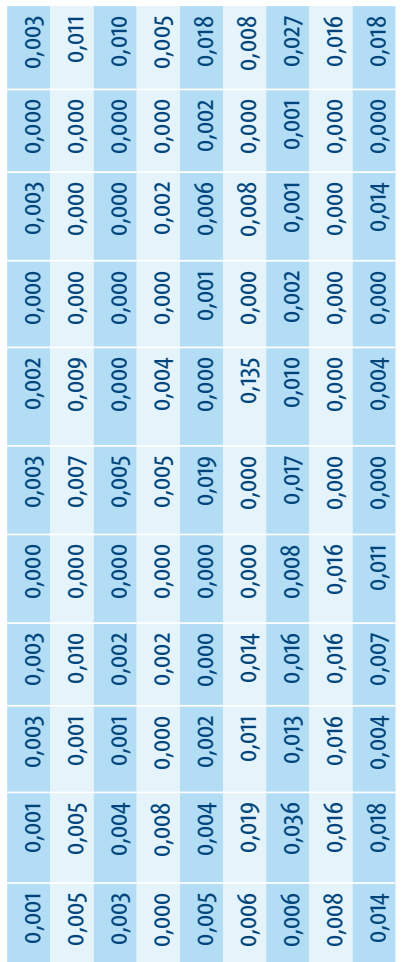

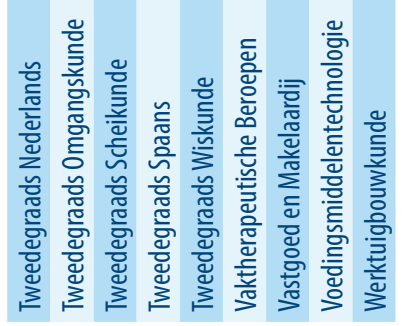




\section{Appendix 4: Text-mining scores per subcluster, masteropleidingen}

\begin{tabular}{|c|c|c|c|c|c|c|c|c|c|c|}
\hline & \multicolumn{5}{|c|}{$\begin{array}{l}\text { Hoofdcluster A: Analytische en } \\
\text { probleemoplossende vaardigheden }\end{array}$} & \multicolumn{5}{|c|}{$\begin{array}{l}\text { Hoofdcluster B: Intermenselijke } \\
\text { vaardigheden }\end{array}$} \\
\hline & 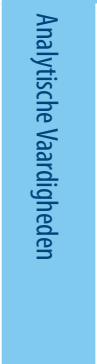 & 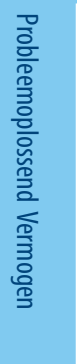 & 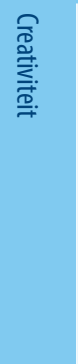 & 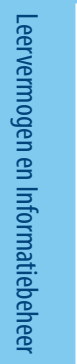 & 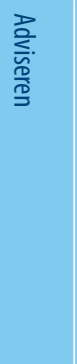 & 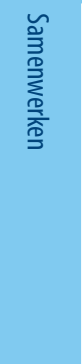 & 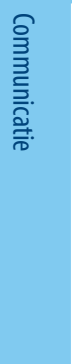 & 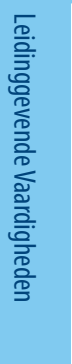 & 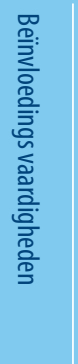 & 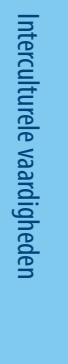 \\
\hline $\begin{array}{l}\text { Beeldende kunst en } \\
\text { Vormgeving }\end{array}$ & 0,030 & 0,015 & 0,012 & 0,000 & 0,000 & 0,010 & 0,020 & 0,005 & 0,002 & 0,000 \\
\hline $\begin{array}{l}\text { Eerstegraads } \\
\text { Aardrijkskunde }\end{array}$ & 0,075 & 0,008 & 0,000 & 0,002 & 0,000 & 0,000 & 0,008 & 0,003 & 0,007 & 0,000 \\
\hline $\begin{array}{l}\text { Eerstegraads } \\
\text { Algemene } \\
\text { Economie }\end{array}$ & 0,065 & 0,005 & 0,001 & 0,006 & 0,000 & 0,002 & 0,035 & 0,002 & 0,005 & 0,000 \\
\hline $\begin{array}{l}\text { Eerstegraads } \\
\text { Biologie }\end{array}$ & 0,017 & 0,005 & 0,000 & 0,001 & 0,000 & 0,003 & 0,025 & 0,013 & 0,001 & 0,000 \\
\hline Eerstegraads Duits & 0,035 & 0,014 & 0,002 & 0,008 & 0,001 & 0,005 & 0,022 & 0,003 & 0,005 & 0,009 \\
\hline Eerstegraads Engels & 0,038 & 0,013 & 0,000 & 0,006 & 0,000 & 0,000 & 0,038 & 0,004 & 0,008 & 0,000 \\
\hline Eerstegraads Frans & 0,036 & 0,012 & 0,001 & 0,011 & 0,000 & 0,003 & 0,022 & 0,007 & 0,004 & 0,002 \\
\hline Eerstegraads Fries & 0,035 & 0,012 & 0,000 & 0,001 & 0,000 & 0,001 & 0,021 & 0,001 & 0,003 & 0,000 \\
\hline $\begin{array}{l}\text { Eerstegraads } \\
\text { Geschiedenis }\end{array}$ & 0,031 & 0,008 & 0,000 & 0,002 & 0,000 & 0,001 & 0,016 & 0,007 & 0,006 & 0,000 \\
\hline $\begin{array}{l}\text { Eerstegraads } \\
\text { Godsdienst }\end{array}$ & 0,014 & 0,014 & 0,002 & 0,003 & 0,000 & 0,000 & 0,003 & 0,003 & 0,003 & 0,000 \\
\hline $\begin{array}{l}\text { Eerstegraads } \\
\text { Lichamelijke } \\
\text { Opvoeding }\end{array}$ & 0,026 & 0,017 & 0,003 & 0,009 & 0,001 & 0,007 & 0,015 & 0,006 & 0,003 & 0,000 \\
\hline $\begin{array}{l}\text { Eerstegraads } \\
\text { Maatschappijleer }\end{array}$ & 0,024 & 0,006 & 0,001 & 0,015 & 0,000 & 0,002 & 0,009 & 0,001 & 0,006 & 0,000 \\
\hline $\begin{array}{l}\text { Eerstegraads } \\
\text { Nederlands }\end{array}$ & 0,048 & 0,012 & 0,001 & 0,001 & 0,005 & 0,000 & 0,034 & 0,002 & 0,005 & 0,000 \\
\hline
\end{tabular}




\begin{tabular}{|c|c|c|c|c|c|c|c|c|c|c|}
\hline $\begin{array}{l}\text { Eerstegraads } \\
\text { Scheikunde }\end{array}$ & 0,041 & 0,006 & 0,000 & 0,001 & 0,001 & 0,000 & 0,021 & 0,007 & 0,004 & 0,000 \\
\hline $\begin{array}{l}\text { Eerstegraads } \\
\text { Wiskunde }\end{array}$ & 0,058 & 0,015 & 0,000 & 0,004 & 0,000 & 0,000 & 0,003 & 0,002 & 0,001 & 0,000 \\
\hline $\begin{array}{l}\text { Interieur } \\
\text { Architectuur }\end{array}$ & 0,046 & 0,014 & 0,004 & 0,000 & 0,000 & 0,006 & 0,012 & 0,000 & 0,003 & 0,000 \\
\hline Kunsteducatie & 0,060 & 0,018 & 0,012 & 0,006 & 0,000 & 0,000 & 0,015 & 0,006 & 0,003 & 0,000 \\
\hline Master of Music & 0,027 & 0,018 & 0,007 & 0,000 & 0,000 & 0,009 & 0,012 & 0,004 & 0,004 & 0,002 \\
\hline Physician Assistant & 0,015 & 0,010 & 0,000 & 0,001 & 0,000 & 0,013 & 0,018 & 0,001 & 0,004 & 0,000 \\
\hline $\begin{array}{l}\text { Speciale } \\
\text { Onderwijszorg }\end{array}$ & 0,008 & 0,003 & 0,000 & 0,003 & 0,000 & 0,025 & 0,011 & 0,007 & 0,003 & 0,000 \\
\hline $\begin{array}{l}\text { Verpleegkundig } \\
\text { Specialist }\end{array}$ & 0,019 & 0,008 & 0,000 & 0,000 & 0,000 & 0,016 & 0,016 & 0,003 & 0,000 & 0,000 \\
\hline
\end{tabular}




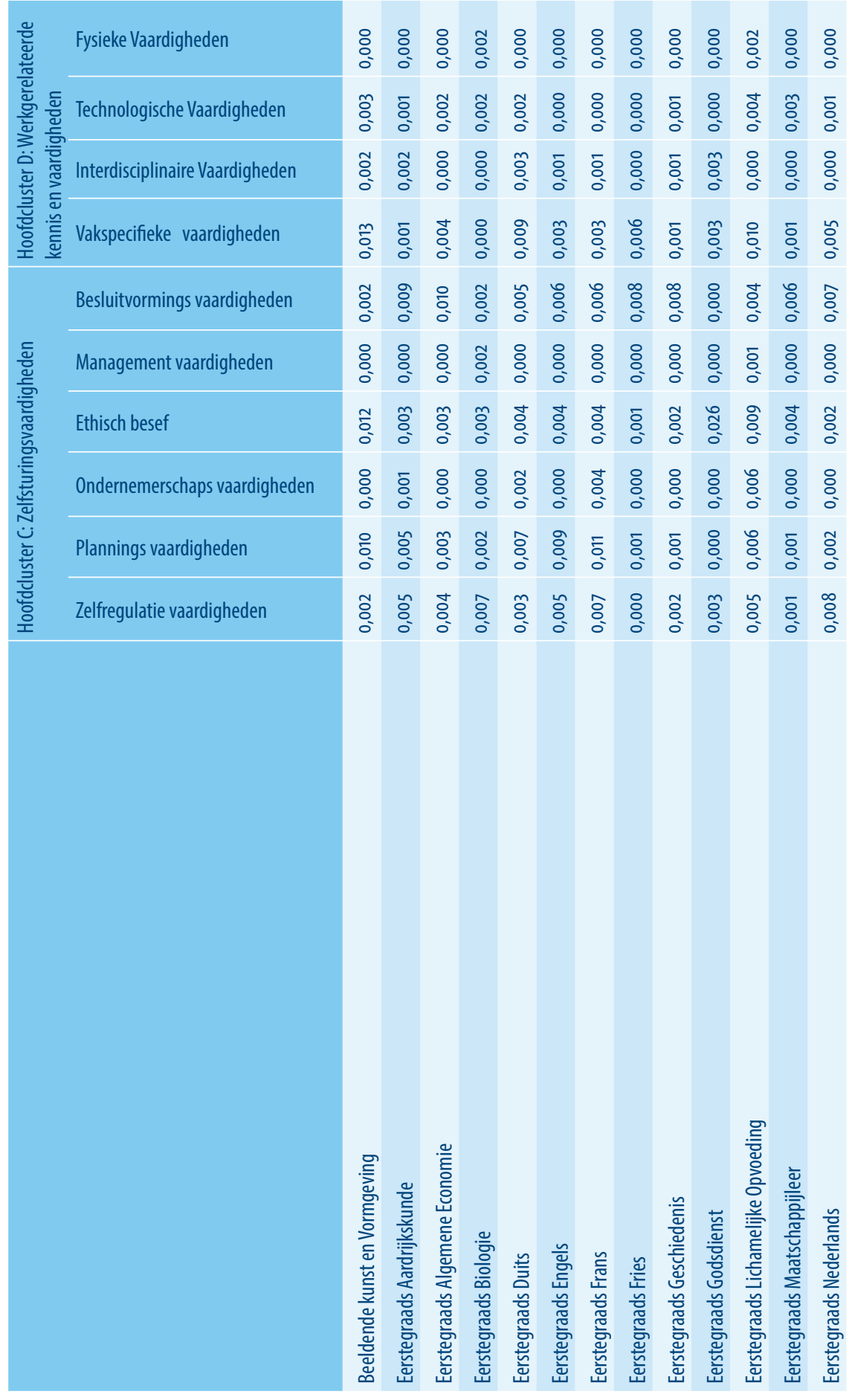




$$
\begin{aligned}
& \text { 홍 영 영 영 영 } \\
& \text { 홍 형 }
\end{aligned}
$$

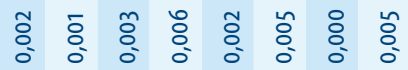

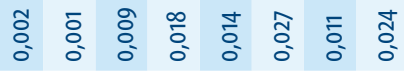

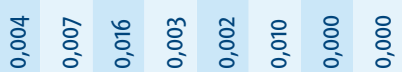

$$
\begin{aligned}
& \text { 형 형 } \\
& \text { 형 형형 }
\end{aligned}
$$

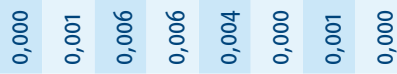

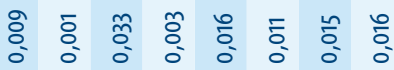

$$
\begin{aligned}
& \text { ถั }
\end{aligned}
$$

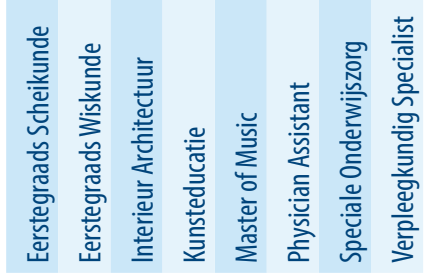

